\title{
CENOMANIAN-CONIACIAN (UPPER CRETACEOUS) BIVALVES OF THE SERGIPE BASIN, BRAZIL: ORDER PHOLADOMYIDA
}

\author{
WAGIH S. AYOUB-HANNAA \\ Geology Department, Faculty of Science, Minufiya University, El-Minufiya, Shibin El Kom, Egypt. Current address: \\ GeoZentrum Nordbayern, Fachgruppe PaläoUmwelt, Friedrich-Alexander-Universität Erlangen-Nürnberg, \\ Loewenichstr. 28,91054 Erlangen, Germany.wagih_hannaa@yahoo.com \\ PETER BENGTSON \\ Institut für Geowissenschaften, Im Neuenheimer Feld 234, 69120 Heidelberg, Germany. \\ peter.bengtson@geow.uni-heidelberg.de
}

FRANZ T. FÜRSICH

GeoZentrum Nordbayern, Fachgruppe PaläoUmwelt, Friedrich-Alexander-Universität Erlangen-Nürnberg, Loewenichstr. 28, 91054 Erlangen, Germany.franz.fuersich@gzn.uni-erlangen.de

\section{EDILMA J. ANDRADE}

Núcleo de Geologia, Universidade Federal de Sergipe, Cidade Universitária, Campus Prof. José Aloísio de Campos, Avenida Marechal Rondon s/nº, 49100-000 São Cristóvão, SE, Brazil. edilmaa@gmail.com

\begin{abstract}
Twenty-two species of the bivalve order Pholadomyida, belonging to six genera and seven subgenera of the families Pholadomyidae, Pleuromyidae and Poromyidae are described from the Cenomanian-Coniacian Cotinguiba Formation of the Sergipe Basin, north-eastern Brazil. Eleven species, Pholadomya (Ph.) cf. agrioensis Weaver, $P h$. (Ph.) kasimiri Pusch, Ph. (Ph.) nodulifera Münster, Ph. (Ph.) occidentalis Morton, Ph. (Procardia) vignesi Lartet, Pleuromya ligeriensis (d'Orbigny), Pl. servesensis Choffat, Liopistha (L.) aequivalvis (Goldfuss), L. (Psilomya) elongata Stanton, L. (P.) globulosa (Forbes) and L. (Sergipemya) gigantea (J. Sowerby) are recorded from the Sergipe Basin for the first time. The new subgenus Sergipemya of the genus Liopistha, family Poromyidae, is erected on the basis of morphological characters such as numerous commarginal ribs, large and highly inflated valves, a well-developed rounded umbonal anterior ridge bordering a deep depression on the anterior part, and the presence of two unequal cardinal teeth with a cardinal tear-shaped socket in the left valve. The pholadomyid fauna of Sergipe closely resembles that of other Tethyan regions in western and southern Europe, northern and western Africa and the Middle East. The distribution patterns of the taxa were probably influenced by east-west-directed currents. Southern Tethyan pholadomyids reached western Africa and north-eastern South America via the Trans-Saharan Seaway.
\end{abstract}

Key words: Pholadomyida, taxonomy, palaeobiogeography, Cretaceous, Cotinguiba Formation, Brazil.

RESUMO - Vinte e duas espécies de biválvios da ordem Pholadomyida pertencentes a seis gêneros e sete subgêneros das famílias Pholadomyidae, Pleuromyidae e Poromyidae são descritas do Cenomaniano-Coniaciano da Formação Cotinguiba, bacia de Sergipe, nordeste do Brasil. Onze espécies são registradas na bacia pela primeira vez: Pholadomya (Ph.) cf. agrioensis Weaver, Ph. (Ph.) kasimiri Pusch, Ph. (Ph.) nodulifera Münster, Ph. (Ph.) occidentalis Morton, Ph. (Procardia) vignesi Lartet, Pleuromya ligeriensis (d'Orbigny), Pl. servesensis Choffat, Liopistha (L.) aequivalvis (Goldfuss), L. (Psilomya) elongata Stanton, L. (P.) globulosa (Forbes) e L. (Sergipemya) gigantea (J. Sowerby). Foi proposto o novo subgênero Sergipemya do gênero Liopistha, família Poromyidae, com base em caracteres morfológicos tais como: valvas grandes e fortemente infladas, costelas comarginais numerosas, uma área umbonal anterior bem desenvolvida e arredondada margeando uma depressão profunda sobre a parte anterior, e a presença de dois dentes cardinais diferentes com um soquete cardinal em forma de ranhura na valva esquerda. A fauna de pholadomyideos de Sergipe assemelha-se fortemente àquela de outras regiões tetianas no oeste e no sul da Europa, no norte e oeste da África e no Oriente Médio. Os padrões de distribuição dos táxons foram influenciados provavelmente por correntes no sentido leste-oeste. Os pholadomyideos tetianos da parte sul alcançaram a África ocidental e o nordeste da América do Sul pela via transsaariana.

Palavras-chave: Pholadomyida, taxonomia, paleobiogeografia, Cretáceo, Formação Cotinguiba, Brasil. 


\section{INTRODUCTION}

Taxonomy of the bivalve order Pholadomyida is, in general, difficult and in part confused. The difficulties result from the great variation in shell outline and number of radial ribs. During the first half of the past century, a large number of new species and varieties were described on the basis of variations in ribbing pattern (Weaver, 1931, p. 316), many of which were considered synonyms by later workers. For instance, Dhondt (1987, p. 89) regarded some species and varieties, such as Pholadomya rostrata Matheron, 1843, and Ph. elisabethae Moesch, 1875, as synonyms of $P h$. $(P h$.) nodulifera Münster, 1841. In fact, taphonomic processes and weathering may strongly modify the ribbing pattern (number and character of ribs) and the shell outline. Most fossil species of pholadomyids appear to have had a prismatic outer shell layer and nacreous middle and inner shell layers, all layers consisting of aragonite (Runnegar, 1972), which commonly has been completely dissolved during diagenesis. In addition, rib characteristics seem to be influenced by, or related to, the grain size of the substrate; in coarse-grained sediments, ribs are fewer, stronger and more subdivided than in fine-grained sediments (Dhondt \& Jagt, 1989). In addition, distortion caused by compaction makes it difficult to reconstruct the original shell outline.

The Sergipe Basin in north-eastern Brazil is the best exposed and arguably the most fossiliferous of the Brazilian continental margin basins. It contains one of the most extensive middle Cretaceous marine successions among the northern South Atlantic basins (e.g. Smith \& Bengtson, 1991; Koutsoukos \& Bengtson, 1993). The CenomanianConiacian succession (Cotinguiba Formation) is well exposed and contains a rich macroinvertebrate fauna dominated by molluses (Bengtson, 1983). Parts of this fauna were illustrated and described in the classical monographs of White (1887) and Maury $(1925,1937)$. More recently, selected groups of molluscs such as oysters, pinnids, pectinids, inoceramids, gastropods, and ammonites have been documented (e.g. Hessel, 1985, 1988; Seeling, 1999; Seeling \& Bengtson; 1999, 2003a,b; Andrade et al., 2004; Andrade, 2005; Gale et al., 2005; Andrade \& Santos, 2011; Lexen, 2013); however, the bivalve order Pholadomyida has so far been little studied from a taxonomic point of view (Seeling, 1999; Andrade et al., 2011; Ayoub-Hannaa et al., 2013).

Specimens of Pholadomyida occur in Sergipe in beds dated with ammonites as Cenomanian to early Coniacian (Bengtson, 1983; Smith \& Bengtson, 1991; Koutsoukos \& Bengtson, 1993; Gale et al., 2005; S.I. Bengtson et al., 2005) and are here the subject of taxonomic study. In addition, species of Pholadomyida from Sergipe identified and illustrated by earlier workers (e.g. White, 1887; Maury, 1925, 1937) are revised. We also discuss the stratigraphic ranges and palaeobiogeographical affinities of the identified taxa.

\section{GEOLOGICAL SETTING}

The Sergipe Basin is located in the eastern, coastal part of the state of Sergipe in north-eastern Brazil (Figures 1A,B).
The basin is structurally one of four sub-basins composing the Sergipe-Alagoas Basin, viz. the Cabo, Alagoas, Sergipe and Jacuípe sub-basins (Souza-Lima et al., 2002).

As a result of the strong tectonic activity that affected north-eastern South America since the beginning of its separation from Africa in the late Mesozoic, a series of halfgrabens were formed, with a regional dip averaging $10-15^{\circ}$ to the south-east. The Sergipe Basin extends offshore and is limited to the south-east by the continental slope and to the north-west by a system of normal faults. Sedimentation was strongly controlled by differential subsidence and halfgraben development along the NE-SW extensional faulting (Koutsoukos et al., 1993). For details about the geological evolution and the development of the marine Cretaceous of the Sergipe Basin, see, for example, Ojeda \& Fugita (1976), Ojeda (1982), Bengtson (1983), Koutsoukos \& Bengtson (1993), Koutsoukos et al. (1993), Feijó (1995) and SouzaLima et al. (2002).

The Mesozoic-Cenozoic sedimentary record of the Sergipe Basin comprises an extensive Tithonian-Aptian non-marine and Aptian-Miocene marine succession (Feijó, 1995; SouzaLima et al., 2002; Campos Neto et al., 2008). Thicknesses vary between 1 and $3 \mathrm{~km}$ onshore, whereas offshore the succession may reach a thickness of $8 \mathrm{~km}$ (Ponte et al., 1980). The marine succession, in particular, is widely exposed and comprises the dominantly carbonate Aptian-Albian Riachuelo and Cenomanian-Coniacian Cotinguiba formations, overlain by the siliciclastic Santonian-Miocene Calumbi Formation (Figures 2A,B; Feijó, 1995). The Cotinguiba Formation, from where the material studied here derives, averages $200 \mathrm{~m}$ in thickness but may locally reach $1000 \mathrm{~m}$ in the onshore part of the basin (Schaller, 1970). The formation consists mainly of grey to blue-grey (cream or yellowish where weathered), massive, fossiliferous, bioturbated, fine-grained limestones with sparse siliciclastic intercalations at the base (Bengtson, 1983). The rich macroinvertebrate fauna is dominated by bivalves (e.g. inoceramids, oysters, pholadomyids, pinnids, pectinids), gastropods, ammonites, echinoids, and crustaceans. The succession accumulated on a carbonate ramp system in neritic to upper bathyal environments with intermittent dysoxic-anoxic bottom conditions and welloxygenated epipelagic waters (Koutsoukos et al., 1991, 1993). The onshore, exposed part of the succession represents predominantly deposition on structural highs in shallow-water neritic conditions.

The biostratigraphic zonation for the marine succession of the Sergipe Basin is based primarily on ammonites, inoceramid bivalves and foraminifers and derives essentially from the work of Bengtson (1983), Kauffman \& Bengtson (1985), Hessel (1988), Smith \& Bengtson (1991), Koutsoukos \& Bengtson (1993), Seeling (1999), Seeling \& Bengtson (1999), Gale et al. (2005), Andrade (2005) and S.I. Bengtson et al. (2005). The currently most detailed scheme for the Cenomanian-Coniacian interval comprises 13 ammonite zones (Figure 2C) and is based on Smith \& Bengtson (1991), Koutsoukos \& Bengtson (1993), Seeling \& Bengtson (1999) and S.I. Bengtson et al. (2005). The position of 
the Cenomanian-Turonian boundary in the basin is well correlated with the GSSP for the base of the Turonian Stage at Pueblo, Colorado, USA (Gale et al., 2005). By contrast, the position of the Turonian-Coniacian boundary is provisional, as the base of the Coniacian Stage has not yet been formally defined by a GSSP (Andrade, 2005; Bengtson et al., 2005). Hence, the late Turonian and early Coniacian ages attributed to some of the specimens described here should, for the present, be regarded as tentative.

\section{MATERIAL AND METHODS}

The bulk of the material studied here was collected by P. and S.I. Bengtson in 1971-1972, with complementary sampling by P. Bengtson in 1977, J. Seeling (Heidelberg University) in 1995-1996 and E.J. Andrade in 2001-2004. The material comprises 133 specimens from 33 localities (Figure 1C) of the Cenomanian-Coniacian Cotinguiba Formation. Locality descriptions are given as follows: Alto Verde 5, Cajaíba 7, Cruzes, 6, 8, Itaporanga 2, 3, Japaratuba 4, 6, 11, Jericó 3, Laranjeiras 21, 22, Machado 2, Mata 9, Muçuca 1, Mucuri 10, Pedra Branca 1, Pedra Furada 3, 4, 5, 7, 8, 16, Pedro Gonçalves 2, São Pedro 1, São Roque 2, 5, Sergipe 5 and Timbó 4 in Bengtson (1983, appendix 1); Retiro 26 in Hessel (1988), Andrade (2005) and Manso \& Andrade (2008); Japaratuba 16 in Seeling (1999), Walter (2000) and Walter et al. (2005); Jardim 31 in Seeling (1999), Walter (2000) and Andrade et al. (2004); Laranjeiras 28 is described below (also in Seeling (1999) and Walter (2000) as "C652”). One specimen (NRM-PZ Mo 167942) was collected in 1969 by R. A. Reyment (Uppsala University) from locality " $2 / 20$ " (Reyment \& Tait, 1972) in the area of localities Cajaíba 7-10.

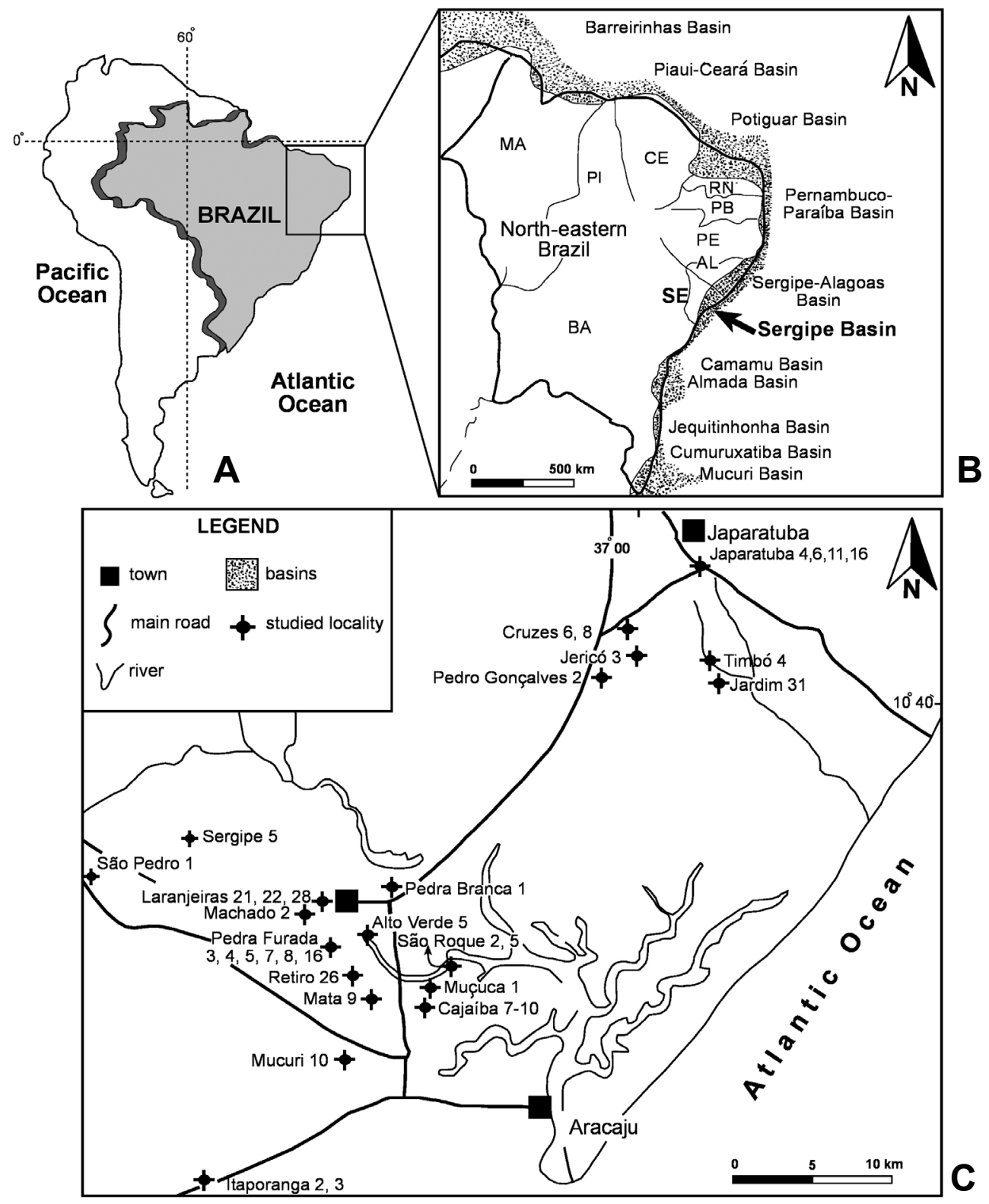

Figure 1. A-B, location of the Sergipe Basin in north-eastern Brazil. C, locality map. Abbreviations of state names: AL, Alagoas; BA, Bahia; CE, Ceará; MA, Maranhão; PB, Paraíba; PE, Pernambuco; PI, Piauí; RN, Rio Grande do Norte; SE, Sergipe. 

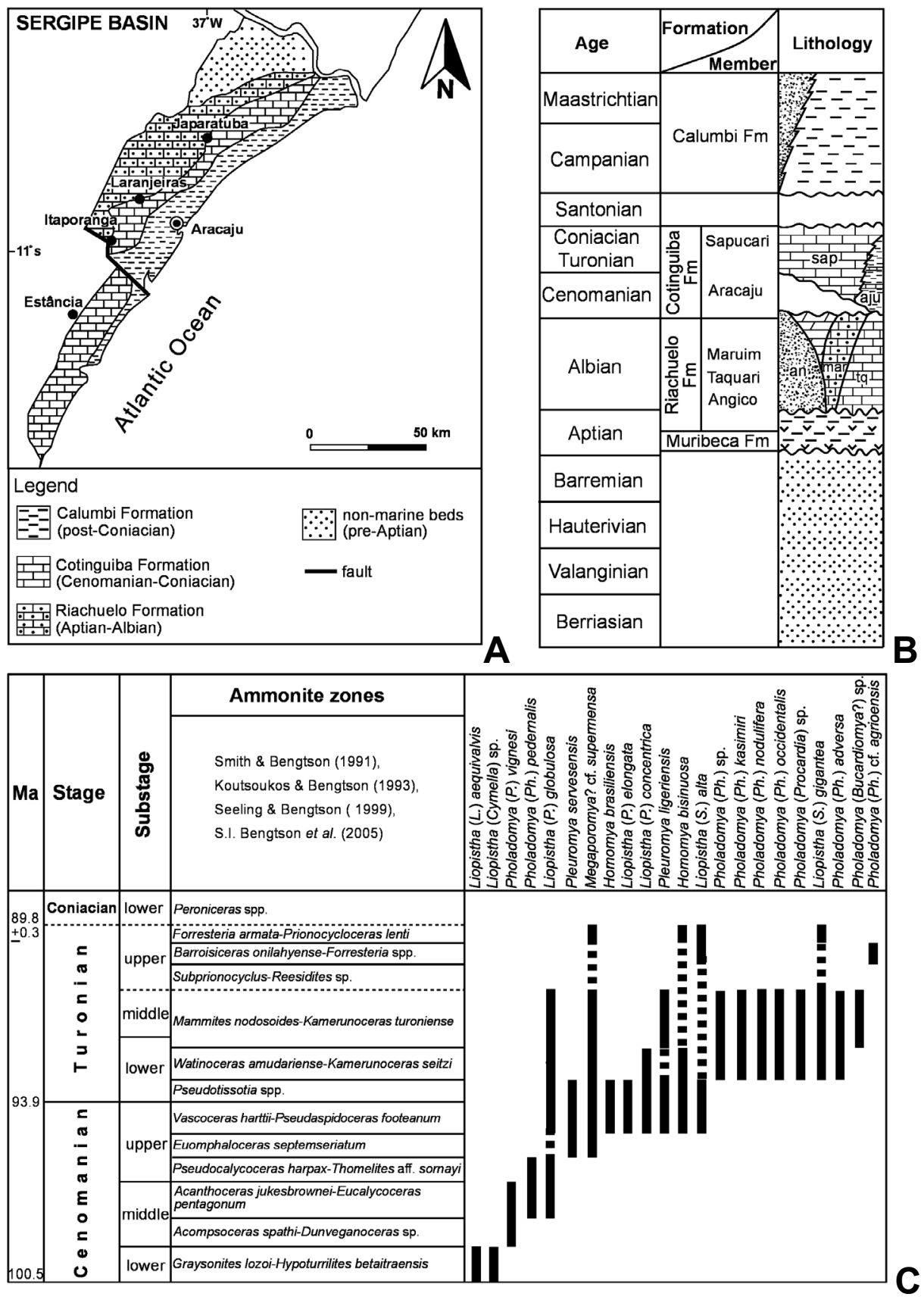

Figure 2. A, generalized geological map of the Sergipe Basin (modified after Koutsoukos \& Bengtson, 1993). B, simplified Cretaceous stratigraphic framework for the Sergipe Basin (modified after Bengtson, 1983; Hessel, 1988; Smith \& Bengtson, 1991; Feijó, 1995; Souza-Lima et al., 2002). C, range chart for Cenomanian-Conaician pholadomyid taxa of the Sergipe Basin. Ammonite zonation after Smith \& Bengtson (1991), Koutsoukos \& Bengtson (1993), Seeling \& Bengtson (1999), S.I. Bengtson et al. (2005).

Most of the specimens are preserved as composite or internal moulds showing ornament and even muscle insertion areas. In a few cases, parts of the originally aragonitic shell are preserved, recrystallized as calcite. Some specimens are laterally deformed due to compaction.

The specimens were prepared mechanically, cleaned and photographed. A principal components analysis (PCA) was carried out to clarify the morphological relationships of some taxa, using the PAST software, version 2.16 (Hammer et al., 2001) on a variance-covariance matrix of the log-transformed variables. Non-metric multidimensional scaling (nMDS) was used to investigate biogeographic relationships. In agreement with Kiessling et al. (2011), although metric multidimensional scaling (MDS) makes fewer assumptions on the nature of the data, it always finds a globally optimum solution, whereas non-metric scaling iteratively seeks the best solution, which may just represent a local optimum. For details about the mechanism and utility of the latter multivariate techniques, see Huntley (2011, p. 28-37).

Linear measurements (taken with a Vernier caliper) are in millimeters. The orientation of measurements is shown in Figure 3. 

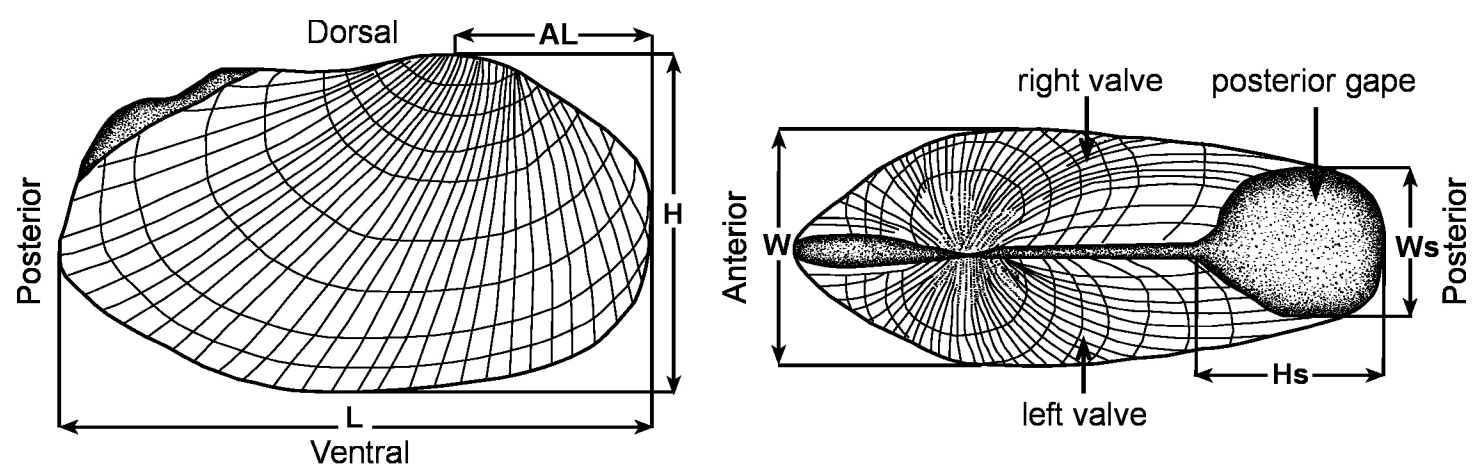

Figure 3. Orientation and measurements of pholadomyid bivalves. A, right lateral view; B, dorsal view. Abbreviations: L, shell length; $\mathbf{H}$, shell height; W, inflation; AL, anterior length; Hs, height of siphonal gape; Ws, width of siphonal gape.

Abbreviations: L, shell length; $\mathbf{H}$, shell height; $\mathbf{W}$, width of articulated valves; $\mathbf{n r}$, number of ribs; $\mathbf{A L}$, anterior length; $\mathbf{H s}$, height of siphonal gape; Ws, width of siphonal gape; $\mathbf{L} / \mathbf{H}$, elongation; $\mathbf{W} / \mathbf{L}$, inflation; $\mathbf{A L} / \mathbf{L}$, length of anterior area; Hs/Ws, elongation of siphonal gape.

The systematic classification of the bivalves follows that of Bieler et al. (2010). For an alternative classification, see Carter et al. (2011). The morphological terminology follows the glossary of Cox (1969a) in the Treatise on Invertebrate Paleontology. The synonymy lists in the present work contain only entries considered to be of major importance for the study and which have been carefully checked by the authors. More comprehensive synonymies can be found in the references cited. Generic diagnoses and remarks are given in cases of ambiguity in the diagnostic features.

Identifiable specimens previously described by Seeling $(1999,2004)$ are listed in Appendix 1, with the revised determinations herein.

The specimens are housed in the collections of the Swedish Museum of Natural History in Stockholm, Sweden (collection acronym NRM-PZ) and the Universidade Federal de Sergipe, Aracaju, Brazil (collection acronym CPUFS-GEO).

\section{Locality description}

LARANJEIRAS 28: UTM 8805 800N/700 600E. Topographical map sheet: SC.24-Z-B-IV Aracaju. Geological map sheet: SC.24-Z- B-IV-4 Aracaju.

Section on hillside facing SE, extending laterally ca. $50 \mathrm{~m}$. Altitude ca. 25-35 m.

Kcsp: Hard, locally bioturbated or coquinoid, light brown to yellowish Laranjeiras limestones.

\section{SYSTEMATIC PALAEONTOLOGY}

Class BIVALVIA Linnaeus, 1758

Subclass AUTOBRANCHIA Grobben, 1894

Order PHOLADOMYIDA Newell, 1965

[= ANOMALODESMATA Dall, 1889]

Superfamily PHOLADOMYOIDEA King, 1844

Family PHOLADOMYIDAE King, 1844

[= ARCOMYIDAE P. Fischer, 1887]

Pholadomya G.B. Sowerby, 1823
Type species. Pholadomya candida G.B. Sowerby, 1823, by subsequent designation of Gray (1847).

Remarks. The generic diagnosis and the stratigraphic distribution of the type species were discussed in detail by Runnegar (1972).

Subgenus Pholadomya J. de C. Sowerby, 1823

Pholadomya (Pholadomya) adversa Riedel, 1933 (Figures 4A-C)

1933 Pholadomya adversa n. sp.: Riedel, p. 149, pl. 6, fig. 1 . 1957 Pholadomya adversa Riedel: Dartevelle \& Freneix, p. 211, pl. 33, fig. 4.

?2008 Pholadomya cf. P. adversa Riedel, 1932: Benaim \& Senra, p. 92, fig. 5.

Material. One composite mould (CPUFS-GEO-643) from the lower-middle Turonian of locality Retiro 26, Cotinguiba Formation, Sergipe, Brazil.

Measurements. See Table 1.

Description. Shell large, oblong to elliptical, equivalved, strongly inequilateral, moderately inflated and elongate posteriorly $(\mathrm{L} / \mathrm{H}=1.75$; Table 1$)$. Postero-dorsal margin concave, nearly parallel to ventral margin. Antero-dorsal margin straight and steeply oblique towards anterior margin. Anterior margin strongly convex, joining ventral margin in a rounded angle. Posterior margin truncated and slightly gaping (Figure 4C). Ventral margin broad, slightly convex and crenulate. Umbonal area wide and convex. Beaks less prominent, nearly orthogyrate, in contact, and situated more than one-third of the total valve length from the anterior end. Lunule wide and concave (Figure 4C). Ornament consisting of well-developed, tuberculate radial ribs (20 ribs with sharp crests) separated by wide interspaces. Radial ribs crossed by thick and irregular commarginal ribs forming reticulate pattern. Anterior and posterior flanks smooth, except for commarginal growth lines.

Discussion. Pholadomya (Pholadomya) adversa is easily distinguished from other pholadomyid species described here by its thick, irregular, commarginal ribs, wide and deep 
Table 1. Dimensions (mm) of Pholadomya (Pholadomya) adversa Riedel, 1932.

\begin{tabular}{|c|c|c|c|c|c|c|c|c|c|c|c|}
\hline Specimen & $\mathrm{L}$ & $\mathrm{H}$ & $\mathrm{W}$ & $\mathrm{AL}$ & $\mathrm{Hs}$ & Ws & $\mathrm{nr}$ & $\mathrm{L} / \mathrm{H}$ & $\mathrm{AL} / \mathrm{L}$ & $\mathrm{Hs} / \mathrm{Ws}$ & $\mathrm{W} / \mathrm{L}$ \\
\hline CPUFS-GEO-643 & 86 & 49.2 & 41 & 30.5 & 28 & 23 & 20 & 1.75 & 0.35 & 1.22 & 0.48 \\
\hline
\end{tabular}

lunule, wide umbonal area, rounded anterior margin, truncated posterior margin, and less prominent beaks.

Pholadomya elliptica Münster, 1841, from the "Senonian" of Germany (Münster in Goldfuss, 1841, pl. 158, fig. 1) resembles $P h$. (Ph.) adversa in having elliptical and moderately inflated valves but differs in its straight to slightly concave postero-dorsal margin, rounded posterior end, shorter anterior area and less developed commarginal ribs. Ph. nodulifera var. elliptica from the Maastrichtian of Poland (Krach, 1931, pl. 7, fig. 10) resembles Ph. (Ph.) adversa in having rounded anterior and ventral margins and a wide umbonal area but differs in being less elongate and in having irregular and thick radial ribs with rounded crests. $P h$. elongata Münster, 1841, from the "Senonian" of Germany (Münster in Goldfuss, 1841, pl. 157, fig. 3) is more inflated and has more numerous radial ribs, subterminal beaks, and a rounded and narrow anterior margin. Ph. agrioensis Weaver, 1931, from the Valanginian of Argentina (Weaver, 1931, p. 316, pl. 36, figs. 205-206) has fewer (11) and thicker radial ribs, a less convex anterior margin and a straight posterodorsal margin.

Occurrence. Turonian of Sergipe, Brazil (this study); Coniacian of Gabon (Dartevelle \& Freneix, 1957), Cameroon (Riedel, 1932) and possibly the Potiguar Basin, Brazil (Benaim \& Senra, 2008); Coniacian-Campanian of Angola and Congo (Dartevelle \& Freneix, 1957).

Pholadomya (Pholadomya) cf. P. agrioensis Weaver, 1931 (Figures 4D-E)

cf. 1931 Pholadomya agrioensis n. sp.: Weaver, p. 316, pl. 36, figs. 205-206.

cf. 2007 Pholadomya agrioensis Weaver, 1931: Lazo, p. 380, fig. $6 \mathrm{~F}-\mathrm{H}$.

Material. One composite mould (NRM-PZ Mo 167818) from the upper Turonian of locality Mata 9, Cotinguiba Formation, Sergipe, Brazil.

Measurements. See Table 2.

Description. Shell large, rectangular-ovate, strongly inequilateral, moderately inflated and elongate posteriorly $(\mathrm{L} / \mathrm{H}=1.64$; Table 2). Maximum inflation below umbonal area, gradually decreasing towards the posterior end. Umbonal area wide and elevated above hinge line. Antero-dorsal margin short and straight. Postero-dorsal margin wide and slightly concave. Posterior margin strongly convex, joining ventral margin in rounded angle. Ventral margin broad, slightly convex, crenulate and nearly parallel to hinge line. A wide and deep sulcus extending from the dorsal side to the antero-ventral margin. Beaks less prominent, prosogyrate, without point of contact, situated approximately one-fourth of the total valve length from the anterior end. Ornament consisting of 12 thick radial ribs (with sharp crests) separated by wide, concave, regular and smooth interspaces (Figure 4E). Posterior flank occupying approximately one-fourth of the total valve length from the posterior end; anterior flank (onefifth of valve length from the anterior end) smooth.

Discussion. The Sergipe specimen resembles Pholadomya agrioensis from the Valanginian of Argentina (Weaver, 1931, p. 316, pl. 36, figs. 205-206) in general outline and number of radial ribs but differs in being larger $(\mathrm{L}=95 \mathrm{~mm}, \mathrm{H}=58 \mathrm{~mm}$ as opposed to $\mathrm{L}=54 \mathrm{~mm}, \mathrm{H}=33 \mathrm{~mm}$; Table 2) and in having regular interspaces across the valve (decreasing towards the posterior flank in Weaver's specimens). In addition, and comparing with $\mathrm{Ph}$. agrioensis as figured and described by Lazo (2007) from the Berriasian-Valanginian of Argentina, the Sergipe specimen differs in being less inflated, larger ( $\mathrm{L}=95 \mathrm{~mm}$ as opposed to $<60 \mathrm{~mm}$ ), and in having radial ribs with sharp crests. Because of the poor preservation of the Sergipe specimen, species identification remains uncertain. In addition, the specimen was collected from a considerably higher stratigraphic level than the Argentine occurrences.

Pholadomya bulgarica Toula, 1889, from the Cenomanian of south-eastern Europe (Toula, 1889, p. 64, pl. 2, fig. 5) resembles the Sergipe specimen in ornament and outline but differs in being less elongate $(\mathrm{L} / \mathrm{H}=1.08$ as opposed to 1.64$)$ and in having a concave postero-dorsal margin. Dhondt \& Dieni (1988, p. 59) considered Ph. agrioensis a synonym of Ph. gigantea (Sowerby, 1836) from the Lower Cretaceous of Sardinia (Italy). However, $P h$. agrioensis clearly differs from $P h$. gigantea in shell size and ornament. Ph. gigantea from the Lower Cretaceous of England (Sowerby, 1836; Fitton, 1837, pl. 14, fig. 1) has numerous straight and regular radial ribs (38-45 with sharp crests), whereas $P h$. agrioensis has few, thick radial ribs (12, with rounded crests), separated by wide and smooth interspaces.

Pholadomya (Ph.) salzbergensis (Andert, 1934) from the Maastrichtian of central Poland (Abdel-Gawad, 1986, p. 179, pl. 44, figs. 1-4), resembles the Sergipe specimen in possessing few radial ribs but differs in having subterminal beaks, well-developed commarginal ribs and a high anterior area (higher than the posterior area). Ph. (Ph.) pedernalis

Table 2. Dimensions (mm) of Pholadomya (Pholadomya) cf. agrioensis Weaver, 1931.

\begin{tabular}{lcccccccc}
\hline Specimen & L & H & W & AL & nr & L/H & AL/L & W/L \\
\hline NRM-PZ Mo 167818 & 95 & 58 & 45 & 25 & 12 & 1.64 & 0.26 & 0.47 \\
\hline
\end{tabular}


Roemer (1852, p. 45, pl. 6, fig. 4) from the Turonian of Texas differs in having fewer (5) and thicker radial ribs, subterminal beaks and in being less elongate.

Occurrence. Berriasian-Valanginian of Argentina (Weaver, 1931; Lazo, 2007); possibly Turonian of Sergipe, Brazil (this study).
Pholadomya (Pholadomya) kasimiri Pusch, 1837

(Figures 4F-H, 5A-G)

1837 Pholadomya kasimiri mirim: Pusch, p. 88, pl. 8, fig. 13. 1841 Pholadomya Esmarki [sic] Pusch [sic]: Goldfuss, p. 272 , pl. 157 , fig. 10a-c,d(?).

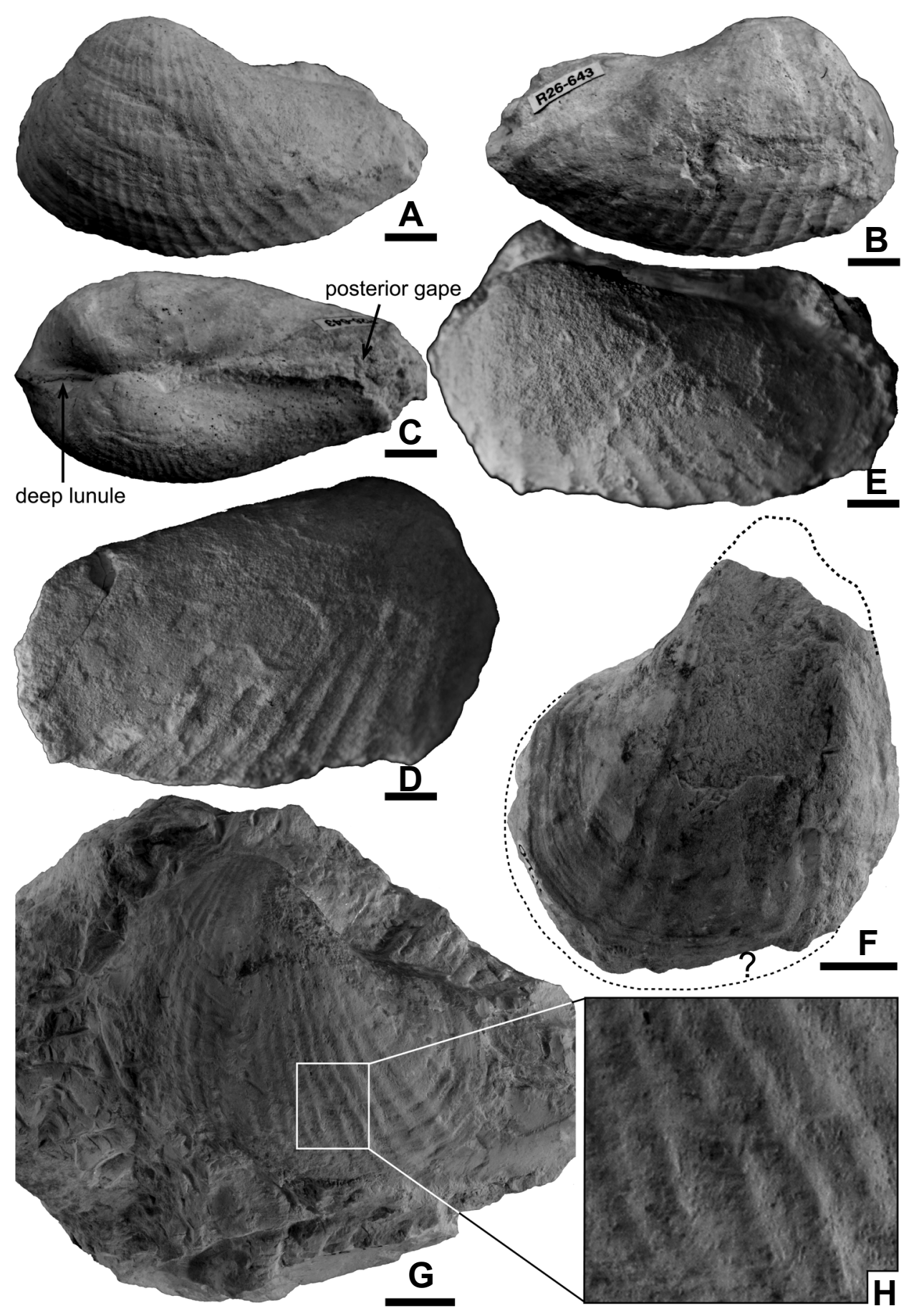

Figure 4. A-C, Pholadomya (Pholadomya) adversa Riedel, 1932 from the lower-middle Turonian of locality Retiro 26 (CPUFS-GEO-643). A, lateral view of left valve; B, right lateral view; C, dorsal view. D-E, Pholadomya (Pholadomya) cf. agrioensis Weaver, 1931, from the upper Turonian of locality Mata 9 (NRM-PZ Mo 167818). D, right lateral view of articulated composite mould; E, left lateral view showing the wide, smooth and concave interspaces between the radial ribs. F-H, Pholadomya (Pholadomya) kasimiri Pusch, 1837, from the lower-middle Turonian. F, right lateral view of incomplete composite mould showing the trigonal form; locality Pedra Furada 3 (NRM-PZ Mo 167819); G, left lateral view of composite mould; $\mathbf{H}$, close-up showing the tuberculate radial ribs; locality Pedra Furada 4 (NRM-PZ Mo 167820). All specimens from the Cotinguiba Formation of the Sergipe Basin, Brazil. Scale bars $=10 \mathrm{~mm}$. 
?1916 Pholadomya occidentalis Morton: Gardner, p. 630, pl. 37, figs. 1-3.

1931 Pholadomya Esmarki [sic] Nilss.: Krach, p. 361, pl. 7, fig. 15; pl. 8, fig. 1.

1986 Pholadomya (Pholadomya) kasimiri Pusch: AbdelGawad, p. 176, pl. 45, figs. 3-4; pl. 46, figs. 4-5.

Material. Nineteen composite moulds (NRM-PZ Mo 167819167837) from the lower-middle Turonian of localities Pedra Furada 3, 4 and 16, São Pedro 1, Laranjeiras 22, and Alto Verde 5, Cotinguiba Formation, Sergipe, Brazil.

Measurements. See Table 3.

Description. Shell medium-sized to large, variable in outline, subtrigonal, trapezoidal to elongate-ovate, equivalved, strongly inequilateral, highly inflated and posteriorly elongate $(\mathrm{L} / \mathrm{H}=1.32$ on average; Table 3$)$. Anterior area short $(\mathrm{AL} / \mathrm{L}=$ 0.21 on average). Maximum inflation slightly below umbonal area, valves increasingly compressed posteriorly. Anterior margin slightly convex to truncated, joining ventral margin in rounded curve. Posterior margin subtruncated and slightly gaping. Antero-dorsal shoulder short, higher than posterodorsal margin, forming an obtuse angle with anterior margin (Figures 5C,D). Postero-dorsal margin concave, bordered by dorsal umbonal ridges and forming a high posterior edge in some individuals (Figures 5D,E). Ventral margin broadly arched and feebly crenulate. Umbonal area wide and moderately convex. Beaks pointed, prosogyrous, positioned near anterior end (one-fifth of total valve length from anterior end). Escutcheon shallow and smooth (Figure 5F). Ornament consisting of 14-18 well-developed, tuberculate radial ribs separated by wide, shallow and concave interspaces. Ribs absent along flattened anterior part, except for commarginal ribs. Faint tubercles present at intersections of radial and commarginal ribs; tubercles well developed dorsally (granular appearance; Figure 4H).

Discussion. The Sergipe specimens show strong similarities to Pholadomya kasimiri from the Campanian-Maastrichtian of central Poland (Pusch, 1837; Abdel-Gawad, 1986) with respect to general outline, size, and number and development of radial ribs. The species is characterized by subterminal beaks, an expanded oval posterior side, and a well-developed umbonal ridge with distinct tuberculate radial ribs, which are absent along the anterior flank.

Goldfuss (1841) considered Pholadomya kasimiri Pusch a synonym in part of Cardita esmarkii Nilsson, 1827. However, he wrongly attributed C. esmarkii to Pusch (1837) (see synonymy herein). In addition, he also described and figured C. esmarkii Nilsson (Goldfuss, 1841, p. 187, pl. 133, fig. 14). Abdel-Gawad (1986) placed the two species in separate subgenera, as Ph. (Pholadomya) kasimiri and Ph. (Bucardiomya) esmarkii. Ph. esmarkii indeed shows similarities to Ph. kasimiri but differs in having subcordate valves, a less expanded posterior area, no umbonal ridge, closely spaced, faint, non-tuberculate radial ribs and in being taller. In addition, Ph. esmarkii possesses a deep umbonalventral sulcus in the middle part of the valve (Nilsson, 1827, pl. 10, fig. $8 \mathrm{C}$ ). The latter, distinct morphological character is absent in Ph. esmarkii, as figured and described by Goldfuss (1841, p. 272, pl. 157, fig. 10d) and Krach (1931, p. 361, pl. 8 , fig. 1). Therefore, their specimens are closer to Ph. kasimiri than to Ph. esmarkii.

On the basis of the H/L ratio, Krach (1931, p. 362) described three forms of Pholadomya esmarkii from the Campanian-Maastrichtian of Poland, viz. (i) an elongate, trapezoidal form $(\mathrm{L}=85, \mathrm{H}=47, \mathrm{~W}=44 \mathrm{~mm}, \mathrm{~L} / \mathrm{H}=1.81)$ with an expanded posterior part, terminal to subterminal beaks, and ornament consisting of 19 radial ribs; (ii) a taller, trigonal form $(\mathrm{L}=83 \mathrm{~mm}, \mathrm{H}=60 \mathrm{~mm}, \mathrm{~W}=53 \mathrm{~mm}, \mathrm{~L} / \mathrm{H}=$ 1.38) ornamented with more numerous radial ribs (30); and (iii) a form similar to the trigonal form but differing in being much taller $(\mathrm{L}=63 \mathrm{~mm}, \mathrm{H}=72 \mathrm{~mm}, \mathrm{~W}=50 \mathrm{~mm}, \mathrm{~L} / \mathrm{H}=$ 0.87 ) and having closely spaced radial ribs, which are less sharp than in the two other forms and restricted to the middle part of the valve.

Abdel-Gawad (1986) also described three forms of Pholadomya kasimiri (a short, elongate, and an intermediate form) based on the $\mathrm{H} / \mathrm{L}$ ratio. In the present study, two forms are recognized, an elongate form, with an expanded posterior area and terminal to subterminal beaks, and a taller, trigonal form. $P h .(P h$.$) kasimiri is highly variable in general outline$ $(\mathrm{L} / \mathrm{H})$ and anterior length $(\mathrm{AL} / \mathrm{L})$. The best separation of the two forms is obtained from the first three principal components that account for a cumulative variance of $95.33 \%$ (PC1: 58.89\%; PC2: 22.53\%; PC3: 13.91\%) (Figure 6E). The anterior length (AL) and its ratio to shell length (AL/L) shows a strong positive correlation with PC1. Low PC1 is associated with wider anterior areas, whereas narrow anterior areas and a terminal to subterminal beaks are characterized by high PC1. Both varieties occur in the two forms of $P h$. $(P h$.) kasimiri illustrated in Figure 6A, whereas $P h$. (Ph.) nodulifera differs in having a wide anterior area (high PC1 scores) and the umbonal area situated one-third of the total shell length from the anterior end. Other variables such as height $(\mathrm{H})$ and width (W) are positively correlated with PC2. This means that individuals with high PC2 scores are much taller and thicker than individuals with low PC2 scores. PC3 accounts for the elongation of the shell $(\mathrm{L} / \mathrm{H})$ and the separation of the two forms. High PC3 values characterize very elongate specimens, whereas specimens with low PC3 values are shorter (trigonal) (Figures 6C,D). Thus, by plotting PC1 vs. PC2 and PC1 vs. PC3 scores of individual specimens, two forms of $P h .(P h$. kasimiri are recognized on the basis of shell outline $(\mathrm{L} / \mathrm{H})$ and position of the umbonal area. However, with respect to other variables such as shell height, inflation, number and distribution of radial ribs, shell margins, and curvature of the umbonal area, the two forms are similar and best referred to the same species.

Pholadomya elliptica Münster, 1841, from the Upper Cretaceous of Germany (Münster in Goldfuss, 1841, p. 275, pl. 158, fig. 1) differs from $P h$. (Ph.) kasimiri in being more elongate and in having a wide anterior area, truncated anterodorsal margin, and a high posterior end. Ph. occidentalis Morton, 1833, from the Upper Cretaceous of the USA (Gardner, 1916, p. 630, pl. 37, figs. 1-3), resembles $P h$. (Ph.) 
Table 3. Dimensions (mm) of Pholadomya (Pholadomya) kasimiri Pusch, 1837.

\begin{tabular}{lcccccccccccc}
\hline Specimen & $\mathrm{L}$ & $\mathrm{H}$ & $\mathrm{W}$ & $\mathrm{AL}$ & $\mathrm{Hs}$ & $\mathrm{Ws}$ & $\mathrm{nr}$ & $\mathrm{L} / \mathrm{H}$ & $\mathrm{AL} / \mathrm{L}$ & $\mathrm{Hs} / \mathrm{Ws}$ & $\mathrm{W} / \mathrm{L}$ \\
\hline NRM-PZ Mo 167819 & 55 & 57 & 40 & 13 & 31 & 12 & 14 & 0.96 & 0.24 & 2.58 & 0.73 \\
NRM-PZ Mo 167820 & 66 & 60 & 50 & 13 & 26 & 10 & 17 & 1.10 & 0.20 & 2.60 & 0.76 \\
NRM-PZ Mo 167821 & 59 & 55 & 34 & 13 & 27 & 15 & 18 & 1.07 & 0.22 & 1.80 & 0.58 \\
NRM-PZ Mo 167822 & 66 & 48 & 40 & 14 & 27 & 16 & 18 & 1.38 & 0.21 & 1.69 & 0.61 \\
NRM-PZ Mo 167823 & 38 & 21 & 20 & 5 & 21 & 7 & 17 & 1.81 & 0.13 & 3.00 & 0.53 \\
NRM-PZ Mo 167824 & 58 & 60 & 42 & 14 & 33 & 11 & 15 & 0.97 & 0.24 & 3.00 & 0.72 \\
NRM-PZ Mo 167825 & 73 & 47 & 42 & 13 & 33 & 11 & 16 & 1.55 & 0.18 & 3.00 & 0.58 \\
NRM-PZ Mo 167826 & 72 & 52 & 43 & 17 & 34 & 17 & 14 & 1.38 & 0.24 & 2.00 & 0.60 \\
NRM-PZ Mo 167827 & 40 & 40 & 37 & 10 & 26 & 13 & 15 & 1.00 & 0.25 & 2.00 & 0.93 \\
NRM-PZ Mo 167828 & 69 & 42 & 36 & 13 & 29 & 10 & 16 & 1.64 & 0.19 & 2.90 & 0.52 \\
NRM-PZ Mo 167829 & 57 & 33 & 32 & 9 & 27 & 12 & 15 & 1.73 & 0.16 & 2.25 & 0.56 \\
NRM-PZ Mo 167830 & 58 & 39 & 35 & 14 & 26 & 12 & 17 & 1.49 & 0.24 & 2.17 & 0.60 \\
NRM-PZ Mo 167831 & 53 & 39 & 28 & 13 & 23 & 12 & 18 & 1.36 & 0.25 & 1.92 & 0.53 \\
NRM-PZ Mo 167832 & 37 & 40 & 28 & 8 & -- & -- & 14 & 0.93 & 0.22 & -- & 0.76 \\
NRM-PZ Mo 167833 & 63 & 42 & 33 & 15 & 31 & 15 & 18 & 1.50 & 0.24 & 2.07 & 0.52 \\
Range & $37-73$ & $21-60$ & $20-50$ & $5-17$ & $21-34$ & $7-17$ & $14-18$ & $0.93-1.81$ & $0.13-0.25$ & $1.69-3.00$ & $0.52-0.93$ \\
Mean & 57.6 & 45 & 36 & 12.27 & 28.14 & 12.35 & 16.13 & 1.32 & 0.21 & 2.36 & 0.63 \\
\hline
\end{tabular}

kasimiri in general outline, shell size, and ornament and is probably a synonym of $P h$. esmarkii.

Occurrence. Turonian of Sergipe, Brazil (this study); Campanian-Maastrichtian of Germany (Goldfuss, 1841), Poland (Pusch, 1837; Krach, 1931; Abdel-Gawad, 1986), Bulgaria and Ukraine (Abdel-Gawad, 1986).

\section{Pholadomya (Pholadomya) nodulifera Münster, 1841}

(Figures 5H-J, 7A-G)

1841 Pholadomya nodulifera: Münster in Goldfuss, p. 273, pl. 158, figs. 2a-b.

?1841 Pholadomya albina Reiche: Roemer, p. 75, pl. 10, fig. 7. 1864 Pholadomya rostrata Matheron: Zittel, p. 115, pl. 2, fig. 2.

1864 Pholadomya rostrata Matheron var. royana d'Orbigny: Zittel, p. 115, pl. 2, fig. 1.

?1883 Pholadomya nodulifera Münster: Frič, p. 107, textfigs. 75a-c, 76.

1889 Pholadomya nodulifera Münster: Holzapfel, p. 155, pl. 15, fig. 1.

1897 Pholadomya nodulifera Münster: Frič, p. 60, text-fig. 71c, ?a-b.

?1931 Pholadomya nodulifera Münster var. elliptica Münster (Scupin, 1913): Krach, 360, pl. 7, figs. 10-11.

1934 Pholadomya nodulifera Münster: Andert, p. 328, pl. 15, figs. 3-4.

1934 Pholadomya nodulifera Münster var. n. fritschi: Andert, p. 332, pl. 15, fig. 5.

1934 Pholadomya nodulifera Münster var. n. salzbergensis: Andert, p. 333, pl. 15, figs. 6-7.

1962 Pholadomya safrensis: Abbass, p. 160, pl. 24, fig. 2.

?1962 Pholadomya vignesi Lartet: Abbass, p. 157, pl. 24, fig. 7. v1983 Pholadomya aff. esmarki [sic] Nilsson: Lefranc in Bengtson, p. 45.

1986 Pholadomya (Pholadomya) salzbergensis Andert: Abdel-Gawad, p. 179, pl. 44, figs. 1-4.

1987 Pholadomya nodulifera Münster: Dhondt, p. 89, pl. 5, figs. 4-5. (With additional synonymy).

2003 Pholadomya (Pholadomya) cf. nodulifera Münster: Szente, p. 167, pl. 1, fig. 26.

Material. Sixteen composite moulds (NRM-PZ Mo 167838167852; CPUFS-GEO-1300) from the lower-middle Turonian of localities Pedra Branca 1, Laranjeiras 22, Pedra Furada 4, 7 and 8, Muçuca 1, and Pedro Gonçalves 2, Cotinguiba Formation, Sergipe, Brazil.

Measurements. See Table 4.

Description. Shell medium-sized to large, variable in outline, elongate-ovate to oblong, strongly inequilateral, equivalved, highly inflated, and posteriorly expanded. Maximum inflation at approximately one-half of total shell length $(\mathrm{W} / \mathrm{L}=0.59$ on average; Table 4). Anterior and posterior margins convex, joining ventral margin in rounded curves. Ventral margin broadly rounded and crenulate. Some individuals bearing wide and deep dorso-ventral sulcus (Figure 7A). Umbonal area wide and strongly convex. Beaks prominent, slightly incurved anteriorly, situated more than one-third of the total valve length from the anterior end. Escutcheon wide, concave and smooth (Figure 5J). Posterior and anterior ends gaping. Ornament consisting of 13-22 radial ribs separated by wide, irregular and smooth interspaces. Radial ribs well developed, irregularly distributed, tuberculate, crossed by irregular commarginal ribs. Intersection of radial and commarginal ribs forming a reticulate pattern, well developed towards the dorsal area. Posterior flank smooth except for commarginal growth lines (Figure 5I). 


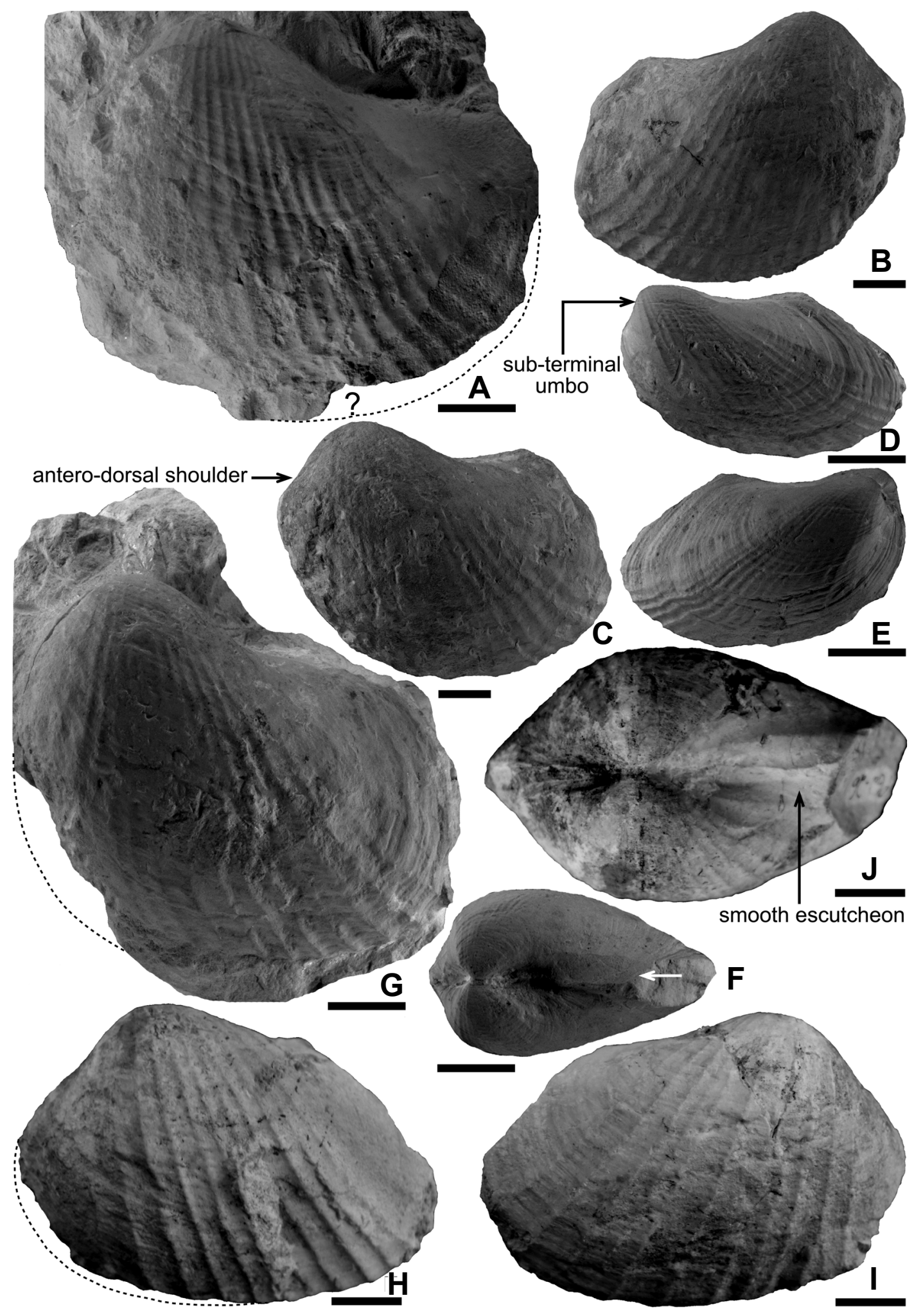

Figure 5. A-G, variation in outline of composite moulds Pholadomya (Pholadomya) kasimiri Pusch, 1837, from the lower-middle Turonian. A, left lateral view, trigonal form with subterminal beaks; locality Pedra Furada 3 (NRM-PZ Mo 167821); B, side view of right valve; C, left lateral view showing anterior shoulder (arrowed); locality Pedra Furada 4 (NRM-PZ Mo 167822); D, side view of left valve showing an elongate form with expanded posterior area and subterminal beaks; $\mathbf{E}$, side view of right valve showing the smooth anterior and posterior flanks; $\mathbf{F}$, dorsal view showing the smooth and shallow escutcheon (arrowed); locality Laranjeiras 22 (NRM-PZ Mo 167824); G, left lateral view, trigonally shaped variety; locality São Pedro 1 (NRM-PZ Mo 167823). H-J, composite mould of Pholadomya (Pholadomya) nodulifera Münster, 1841, from the lower-middle Turonian of locality Pedro Gonçalves 2 (CPUFS-GEO-1300). H, side view of left valve showing well-developed radial ribs with sharp crests, separated by wide and strongly concave interspaces; I, right lateral view; J, dorsal view of both valves showing wide and smooth escutcheon with wide posterior gape. All specimens from the Cotinguiba Formation of the Sergipe Basin, Brazil. Scale bars $=10 \mathrm{~mm}$. 


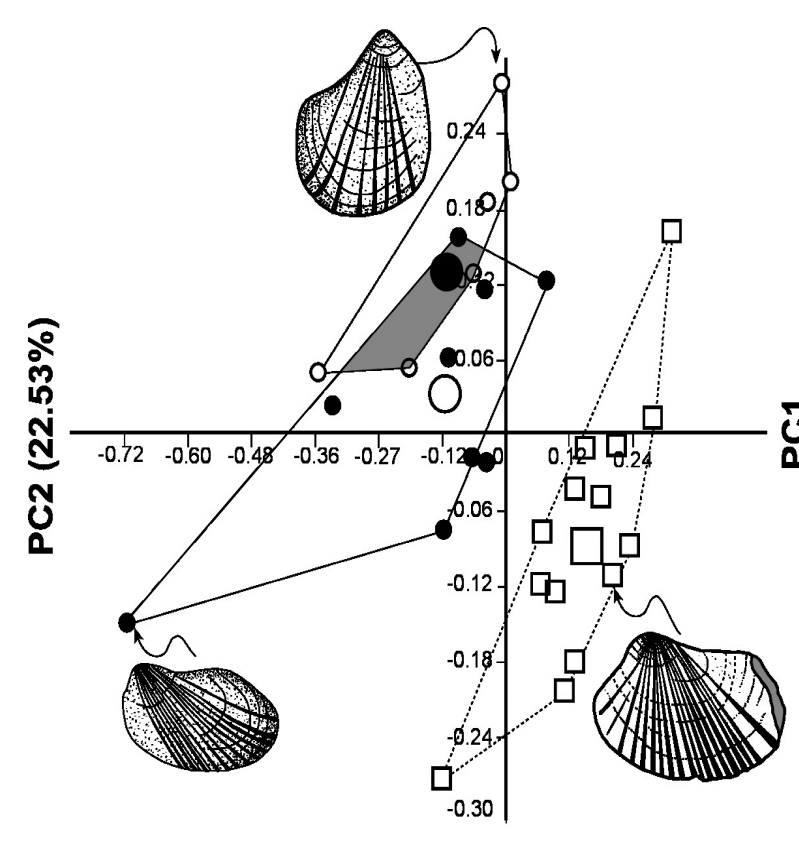

PC1 (58.89\%)
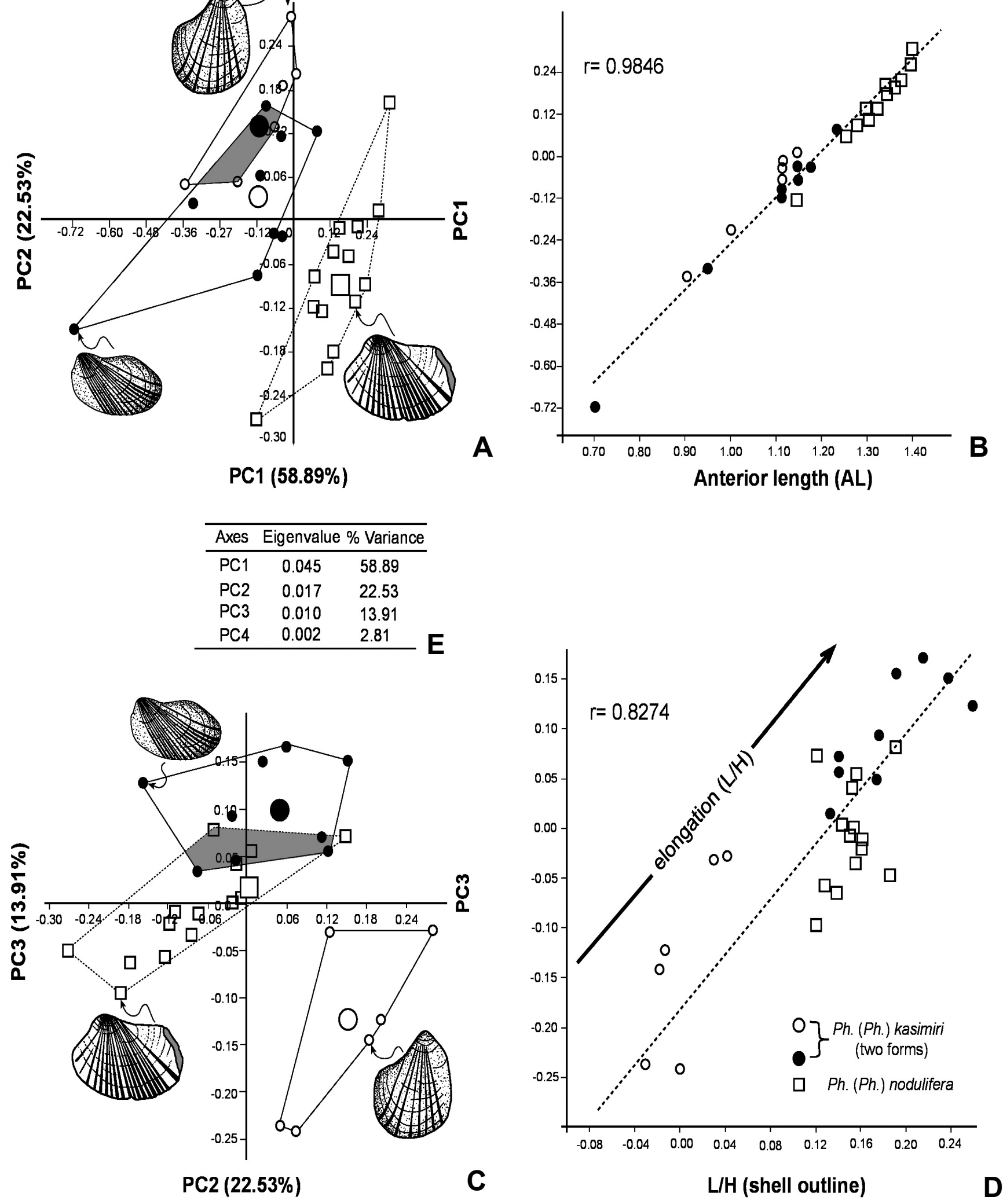

Figure 6. Principal component analysis (PCA) of Pholadomya (Pholadomya) kasimiri Pusch, 1837, and Ph. (Ph.) nodulifera Münster, 1841, using the PAST software (Hammer et al. 2001). A, scatter plot of PC1 vs. PC2 showing the separation between the two species on the basis of the anterior length $(\mathbf{A l})$ and $\mathrm{Al} / \mathrm{L}$ ratio; $\mathbf{B}$, relationship between $\mathrm{PC} 1$ and anterior length $(\mathrm{Al})$ showing that $P h$. (Ph.) nodulifera has a much greater anterior length (PC1 score ranges from -0.12 to 0.30 ) than the two forms of $P h$. (Ph.) kasimiri; C, scatter plot of PC2 vs. PC3 showing the separation between the two species based on shell outline $(\mathrm{H} / \mathrm{L})$; $\mathbf{D}$, relationship between PC3 and shell outline $(\mathrm{H} / \mathrm{L})$ showing that the elongate form of $P h$. (Ph.) kasimiri is taller than the trigonal form and $P h$. (Ph.) nodulifera (PC3 scores range from 0.0 to 0.15 ); E, percentage of variation explained by PCA of body-size variables. The large symbols in the scatter plots represent the centroid value for the respective groups. 
Discussion. Pholadomya $(P h$.) nodulifera is a highly variable species but is readily distinguished by its comparatively few and irregular radial ribs, rounded margins, crenulate ventral margin, well-developed umbonal ridge, wide anterior area (high PC1 scores, Figures 6A,B), wide siphonal gape, dorsoventral sulcus (in some individuals) and smooth posterior flank, except for commarginal growth lines.

As a result of the high variability, the species has been split into varieties. For instance, Andert (1934) described the varieties fritschi and salzbergensis, separated by differences in number and sharpness of radial ribs (var. salzbergensis has few, sharp, radial ribs). In agreement with Dhondt (1987), these two varieties and some other species such as Pholadomya albina Reiche in Roemer, 1841, Ph. elisabethae Moesch, 1875, and Ph. micronodulifera Sobetski, 1977, are here regarded as junior synonyms of $P h$. $(P h$.) nodulifera (Figure 8). Ph. nodulifera var. elliptica Krach, 1931, from the Maastrichtian of Poland differs in having well-developed, irregular, rounded radial ribs, which cover the entire valve surface. Krach's variety elliptica is considered here a possible synonym of $P h$. (Ph.) nodulifera.

The general outline and ribbing pattern of Pholadomya vignesi Lartet, 1877, from the Cenomanian of the Eastern Desert of Egypt (Abbass, 1962, p. 158, pl. 24, fig. 7) are closely similar to those of $P h$. (Ph.) nodulifera. Abbass (1962, p. 160, pl. 24, fig. 2) described the new species $P h$. safrensis from the Cenomanian of the Sinai Peninsula on the basis of a wide posterior gape, truncated posterior margin and highly inflated valves. However, with respect to shell outline, size, inflation, and ornament, $P h$. safrensis is identical to $P h$. $(P h$. nodulifera and here considered a junior synonym.

Pholadomya (Ph.) kasimiri resembles $P h$. (Ph.) nodulifera in possessing an umbonal keel and rounded margins but differs in its terminal to subterminal beaks, narrow posterior gape, well-developed, tuberculate radial ribs covering the entire valve, and in being less elongate $(\mathrm{L} / \mathrm{H}=1.32$ vs. 1.42 on average for the Sergipe specimens).

Pholadomya speetonensis Woods, 1909, from the Lower Cretaceous of England (Woods, 1909, p. 248, pl. 41, fig. 4) closely resembles $P h$. $(P h$.) nodulifera in general outline $(\mathrm{L} / \mathrm{H}=1.38)$, number of radial ribs and rounded shell margins but has less prominent and nearly orthogyrate beaks, thick, flat-crested radial ribs with wide, smooth, and flat interspaces. Ph. agrioensis Weaver, 1931, from the Valanginian of Argentina (Weaver, 1931, p. 316, pl. 36, figs. 205-206) resembles $P h .(P h$.$) nodulifera in possessing a dorso-ventral$ sulcus but differs in being more elongate and in having thick, rounded radial ribs. Ph. umbonata Roemer, 1841, from the Upper Cretaceous of Germany (Roemer, 1841, pl. 10, fig. 6) is also similar to $P h$. $(P h$.) nodulifera in its elongate-ovate valves but differs in having fewer ribs covering only the anterior third of the flank.

Occurrence. Cenomanian of Egypt (Abbass, 1962) and central Asia (Dhondt 1987, p. 91); Turonian of Sergipe, Brazil (this study); Turonian-Coniacian of Germany (Roemer, 1841; Holzapfel, 1889), north-eastern Alps (Zittel, 1864), and the Czech Republic (Andert, 1934); upper Santonian of Austria
(Dhondt, 1987; Szente, 2003); Maastrichtian of Poland (Krach, 1931; Abdel-Gawad, 1986).

Pholadomya (Pholadomya) occidentalis Morton, 1833 (Figures 7H-K, 9A)

1833 P. occidentalis, (S.G.M.): Morton, p. 292, pl. 8, fig. 3. 1907 Pholadomya occidentalis Morton: Weller, p. 513, pl. 56, figs. 1-3.

1926 Pholadomya occidentalis Morton: Wade, p. 72, pl. 23, figs. 13-15.

1954 Pholadomya occidentalis Morton: Groot et al., p. 45, pl. 5 , fig. 1.

1958 Pholadomya occidentalis Morton: Richards, p. 158, pl. 26, figs. 3-4.

1972 Pholadomya occidentalis Morton: Pickett, pl. 3, fig. 1.

Material. Seven composite moulds (NRM-PZ Mo 167853167859) from the lower-middle Turonian of localities Laranjeiras 22, Pedra Furada 4 and 5, and Machado 2, Cotinguiba Formation, Sergipe, Brazil.

Measurements. See Table 5.

Description. Shell large, equivalved, strongly inequilateral, highly inflated and extended posteriorly; lateral outline elliptical. Maximum inflation slightly below umbonal area, gradually decreasing towards posterior side $(\mathrm{W} / \mathrm{L}=0.58$ on average; Table 5). Length of nearly horizontal postero-dorsal margin two-thirds of valve length and parallel to ventral margin. Antero-dorsal margin short $(\mathrm{AL} / \mathrm{L}=0.11$ on average; Table 5), rounded, steeply oblique, joining anterior margin in rounded angle. Ventral margin broadly rounded, crenulate, joining posterior margin in rounded angle. Posterior margin slightly rounded, higher than anterior margin and widely gaping. Umbonal area wide and highly inflated. Beaks prominent, terminal, incurved anteriorly, elevated above hinge line, situated less than one-sixth of the total valve length from the anterior end (Figures $7 \mathrm{H}, \mathrm{J}$ ). Ornament consisting of 14-18 irregular, spinose, radial ribs, crossed by irregular commarginal growth lines forming a dorsal grid-like pattern (Figure 7I). Radial ribs thick, rounded, serrated, widely separated towards postero-ventral side and becoming finer and closely spaced dorsally and anteriorly. Commarginal ribs well developed towards ventral side and separated by wide interspaces. Hinge and other internal features not visible. Specific determination of specimen NRM-PZ Mo 167859 uncertain due to poor preservation.

Discussion. Pholadomya (Pholadomya) occidentalis is readily distinguished from other pholadomyid species from the Sergipe Basin by the following features: (i) large shell, (ii) terminal beaks; (iii) wide posterior gape; (iv) irregular, tuberculate radial ribs, fine and closely spaced anteriorly, thick and widely spaced posteriorly; (v) small anterior area; (vi) broadly rounded ventral margin; (vii) maximum shell height near the posterior end; (viii) crenulate ventral margin. Pholadomya tippana Conrad, 1858, from the Upper Cretaceous of Owl Creek, Missouri, USA (Stephenson, 1955, p. 115, pl. 8, figs. 8-13), shows strong similarities to $P h$. $(P h$. 
Table 4. Dimensions (mm) of Pholadomya (Pholadomya) nodulifera Münster in Goldfuss (1841).

\begin{tabular}{lcccccccccccccc}
\hline Specimen & $\mathrm{L}$ & $\mathrm{H}$ & $\mathrm{W}$ & $\mathrm{AL}$ & $\mathrm{nr}$ & $\mathrm{Hs}$ & $\mathrm{Ws}$ & $\mathrm{L} / \mathrm{H}$ & $\mathrm{AL} / \mathrm{L}$ & $\mathrm{Hs} / \mathrm{Ws}$ & $\mathrm{W} / \mathrm{L}$ \\
\hline CPUFS-GEO-1300 & 63 & 44 & 38 & 24 & 13 & 31 & 19 & 1.43 & 0.38 & 1.63 & 0.60 \\
NRM-PZ Mo 167838 & 86 & 65 & 50 & 25 & 17 & -- & -- & 1.32 & 0.29 & -- & 0.58 \\
NRM-PZ Mo 167839 & 54 & 40 & 32 & 19 & 16 & 29 & 14 & 1.35 & 0.35 & 2.07 & 0.59 \\
NRM-PZ Mo 167840 & 68 & 48 & 41 & 22 & 22 & 37 & 17 & 1.42 & 0.32 & 2.17 & 0.60 \\
NRM-PZ Mo 167841 & 64 & 46 & 40 & 20 & 18 & 35 & 21 & 1.39 & 0.31 & 1.67 & 0.63 \\
NRM-PZ Mo 167842 & 63 & 44 & 37 & 20 & 15 & 28 & 14 & 1.43 & 0.32 & 2.00 & 0.59 \\
NRM-PZ Mo 167843 & 55 & 38 & 34 & 18 & 19 & 30 & 16 & 1.45 & 0.33 & 1.87 & 0.62 \\
NRM-PZ Mo 167844 & 62 & 44 & 35 & 23 & 18 & -- & -- & 1.41 & 0.37 & -- & 0.56 \\
NRM-PZ Mo 167845 & 50 & 38 & 30 & 20 & 18 & 26 & 11 & 1.32 & 0.40 & 2.36 & 0.60 \\
NRM-PZ Mo 167846 & 58 & 40 & 35 & 18 & 15 & 45 & 25 & 1.45 & 0.31 & 1.80 & 0.60 \\
NRM-PZ Mo 167847 & 75 & 52 & 43 & 25 & 18 & 36 & 16 & 1.44 & 0.33 & 2.25 & 0.57 \\
NRM-PZ Mo 167848 & 54 & 39 & 30 & 21 & 15 & 31 & 14 & 1.38 & 0.39 & 2.21 & 0.56 \\
NRM-PZ Mo 167849 & 70 & 45 & 38 & 22 & 17 & -- & -- & 1.56 & 0.31 & -- & 0.54 \\
NRM-PZ Mo 167850 & 43 & 28 & 25 & 14 & 18 & 23 & 11 & 1.54 & 0.33 & 2.09 & 0.58 \\
Range & $43-86$ & $28-65$ & $25-50$ & $14-25$ & $13-22$ & $23-45$ & $11-25$ & $1.32-1.56$ & $0.29-0.40$ & $1.63-2.36$ & $0.54-0.63$ \\
Mean & 61.78 & 43.64 & 36.28 & 20.78 & 17 & 31.90 & 16.18 & 1.42 & 0.34 & 2.01 & 0.59 \\
\hline
\end{tabular}

occidentalis in ribbing pattern, inflation, and development of the umbonal area but differs in being less elongate $(\mathrm{L} / \mathrm{H}$ $=1.23-1.26$ as opposed to 1.55 on average for the Sergipe specimens; Table 5) and in having subterminal beaks. Ph. conradi Gardner, 1916, from the Upper Cretaceous of the USA (Gardner, 1916, p. 632, pl. 38, fig. 1) closely resembles $P h$. $(P h$.) occidentalis in having terminal beaks, elliptical valves and a broad and rounded ventral margin but lacks radial ribs on the anterior and posterior thirds of the valve. $P h$. conradi is probably a synonym of $P h .(P h$. occidentalis, and the presence or absence of radial ribs depends mainly on the state of preservation. Ph. gigantea (J. de C. Sowerby, 1836), recorded from the Lower Cretaceous of France, Germany, Mexico, Argentina, Chile and Oman (see Lazo, 2007, p. 380), resembles Ph. (Ph.) occidentalis in general outline and shell size but differs in having a wide anterior area, subterminal beaks (situated one-fourth of the total shell length from the anterior end) and numerous regular and straight radial ribs (38-45; see Weaver, 1931, p. 314). In addition, $P h$. gigantea is recorded from a lower stratigraphic level, viz., Tithonian?-Valanginian to upper Aptian (Dhondt \& Dieni, 1988; Lazo, 2007). Ph. elongata Münster, 1841, from the Upper Cretaceous of Switzerland (Münster in Goldfuss, 1841, p. 270, pl. 157, fig. 3) resembles $P h$. (Ph.) occidentalis in having terminal beaks but is less inflated and more elongate and has a narrower anterior area and more numerous radial ribs (34) with intercalatories.

Occurrence. Turonian of Sergipe, Brazil (this study); Upper Cretaceous, mainly Campanian-Maastrichtian of the United States Atlantic coastal plain (Morton, 1833; Weller, 1907; Richards, 1958; Pickett, 1972; Sohl \& Koch, 1984), Tennessee (Wade, 1926), and Mexico (Vega et al., 1995).

\section{Pholadomya (Pholadomya) pedernalis Roemer, 1852} (Figures 9B-E)
1852 Pholadomya pedernalis $\mathrm{n}$. sp.: Roemer, p. 45, pl. 6 , fig. 4.

1912 Pholadomya pedernalis Roemer: Pervinquière, p. 288, pl. 21, figs. 5-7.

1957 Pholadomya cf. pedernalis Roemer: Dartevelle \& Freneix, p. 210, pl. 33, fig. 3.

1958 Pholadomya aff. pedernalis Roemer: Barber, p. 28, pl. 8, fig. 5; pl. 9, figs. 8-9.

1962 Pholadomya pedernalis Roemer: Abbass, p. 161, pl. 24, fig. 4.

1999 Pholadomya (Pholadomya) cf. pedernalis Roemer: Seeling, p. 134, pl. 5, fig. 19.

2004 Pholadomya pedernalis Roemer: Abdel-Gawad et al., pl. 4 , fig. 5.

?2004 Pholadomya pedernalis Roemer: Akpan \& Ntekim, p. 30 , fig. 6q.

?2006 Pholadomya (Pholadomya) pedernalis Roemer: El Qot, p. 90, pl. 18, figs. 4, 5a-b.

?2007 Pholadomya (Pholadomya) pedernalis Roemer: Mekawy, p. 236, pl. 5, figs.16-17.

2008 Pholadomya (Pholadomya) pedernalis Roemer: Mekawy \& Abu-Zied, p. 314, pl. 3, fig. 13.

2014 Pholadomya (Pholadomya) pedernalis Roemer, 1852: Ayoub-Hannaa et al., p. 125, pl. 12, fig. 5.

Material. Six composite moulds (NRM-PZ Mo 167860167865) from the middle-upper Cenomanian of localities Cruzes 6 and 8 and the upper Cenomanian of Timbó 4, Cotinguiba Formation, Sergipe, Brazil.

Measurements. See Table 6.

Description. Shell small to medium-sized, elongate-ovate, equivalved, strongly inequilateral and posteriorly expanded. Greatest inflation slightly below umbonal area $(\mathrm{W} / \mathrm{L}=$ 0.69 on average; Table 6). Anterior end nearly as high as posterior end. Anterior margin truncated, sloping steeply to 


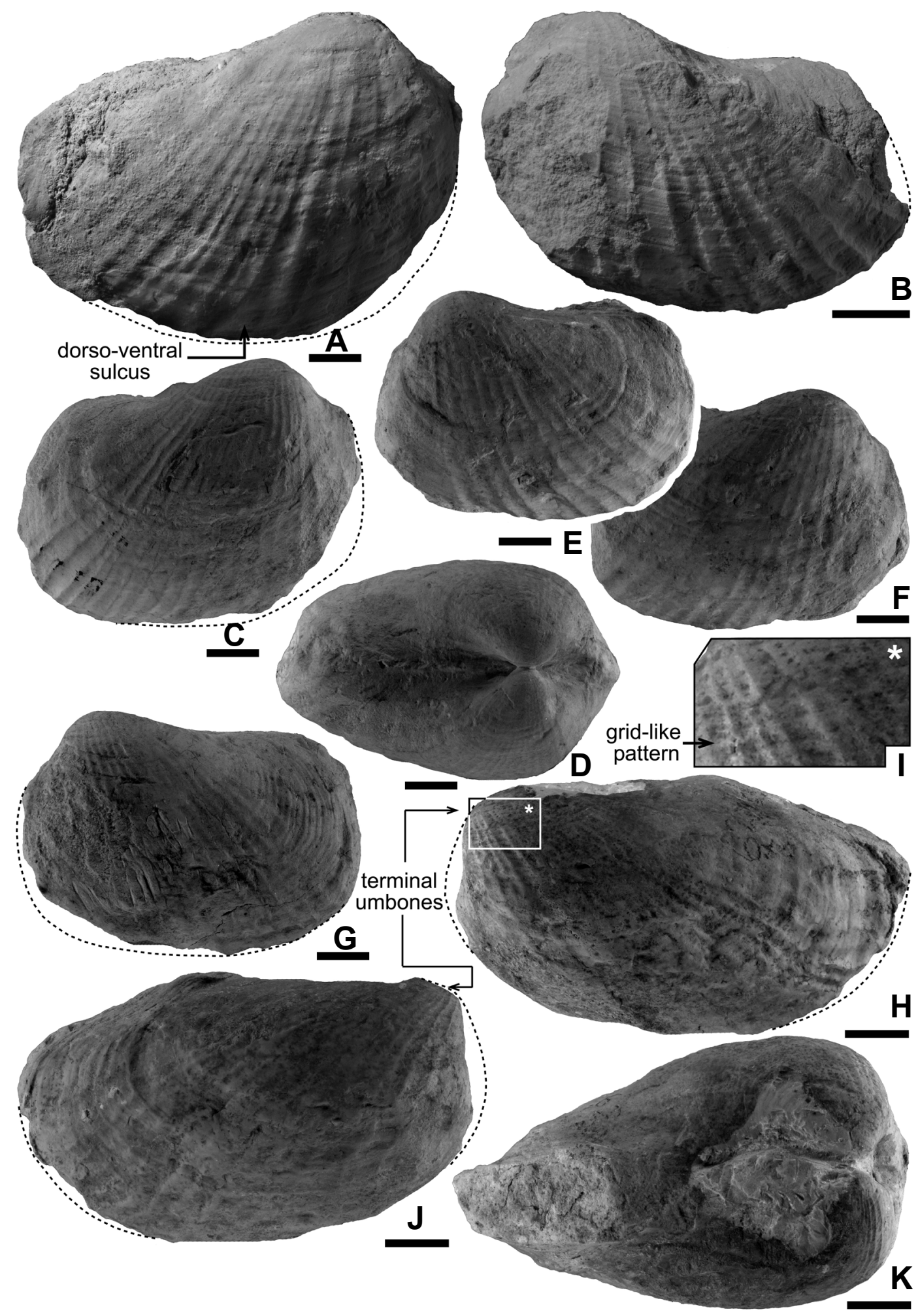

Figure 7. A-G, variation in outline of Pholadomya (Pholadomya) nodulifera Münster, 1841; composite moulds from the lower-middle Turonian. A, right lateral view showing the deep umbonal-ventral sulcus; locality Pedra Branca 1 (NRM-PZ Mo 167838); B, side view of left valve showing irregular and sharp radial ribs; locality Laranjeiras 22 (NRM-PZ Mo 167839); C, right lateral view; D, dorsal view showing deep escutcheon and highly inflated valves; locality Pedra Furada 4 (NRM-PZ Mo 167840); E, side view of left valve; F, side view of right valve showing a wide umbonal area; locality Pedra Furada 4 (NRM-PZ Mo 167841); G, left lateral view showing the oblong outline of the left valve and smooth posterior flank (covered only with commarginal growth lines); locality Muçuca 1 (NRM-PZ Mo 167842). H-K, Pholadomya (Pholadomya) occidentalis Morton, 1833; composite mould from the lower-middle Turonian of locality Laranjeiras 22 (NRM-PZ Mo 167853). H, side view of left valve showing the extreme terminal beaks and strongly extended posterior area; I, close-up showing grid-like pattern on the dorsal surface of left valve; J, Right lateral view showing irregular tuberculate radial ribs; K, dorsal view of highly inflated, articulated specimen. All specimens from the Cotinguiba Formation of the Sergipe Basin, Brazil. Scale bars $=10 \mathrm{~mm}$. 

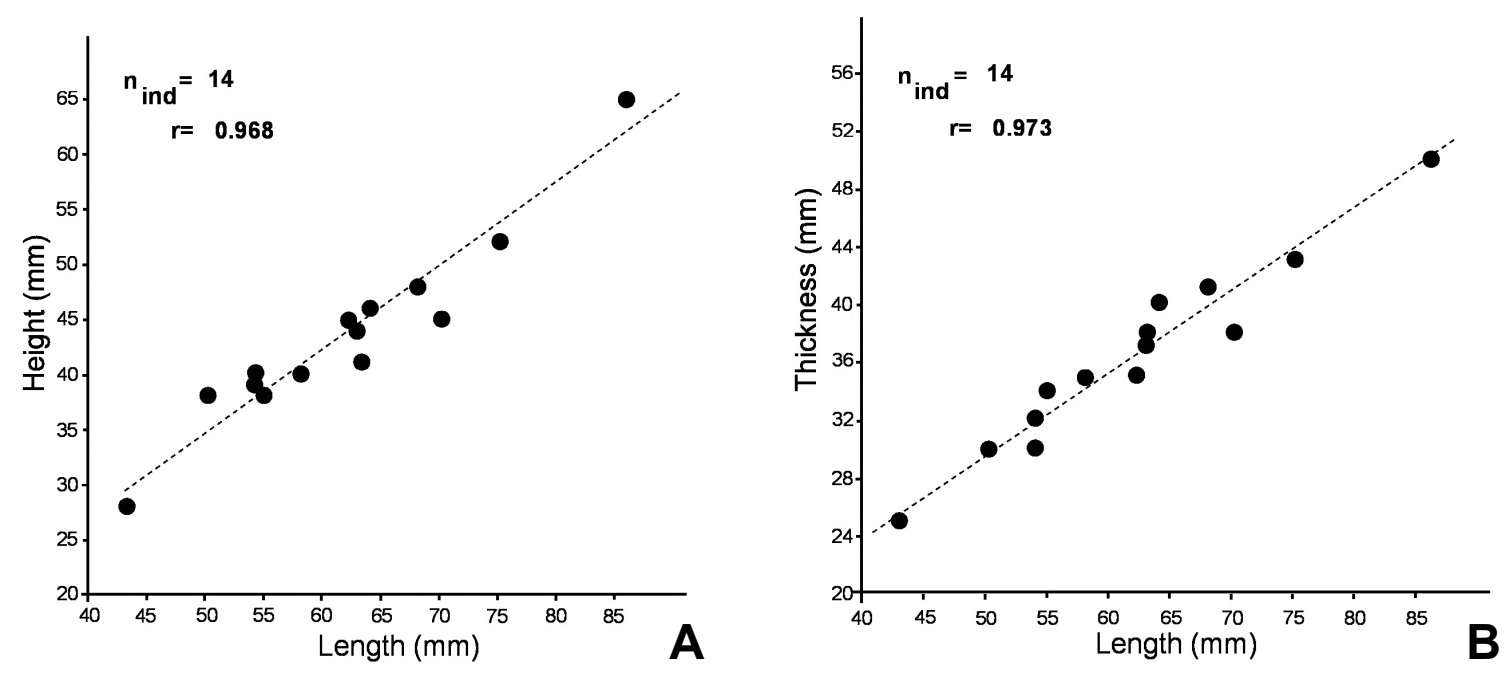

Figure 8. Length/height ratio (A) and length/inflation ratio (B) of Pholadomya (Pholadomya) nodulifera Münster, 1841, from the lower-middle Turonian of the Sergipe Basin, Brazil.

Table 5. Dimensions (mm) of Pholadomya (Pholadomya) occidentalis Morton, 1833.

\begin{tabular}{lccccccccccc}
\hline Specimen & $\mathrm{L}$ & $\mathrm{H}$ & $\mathrm{W}$ & $\mathrm{AL}$ & $\mathrm{Hs}$ & $\mathrm{Ws}$ & $\mathrm{nr}$ & $\mathrm{L} / \mathrm{H}$ & $\mathrm{AL} / \mathrm{L}$ & $\mathrm{Hs} / \mathrm{Ws}$ & $\mathrm{W} / \mathrm{L}$ \\
\hline NRM-PZ Mo 167853 & 76 & 45 & 35 & 7 & 36 & 15 & 18 & 1.69 & 0.09 & 2.40 & 0.46 \\
NRM-PZ Mo 167854 & 81 & 48 & 42 & 8 & 35 & 21 & 16 & 1.69 & 0.10 & 1.67 & 0.52 \\
NRM-PZ Mo 167855 & 63 & 40 & 43 & 8 & 28 & 15 & 16 & 1.58 & 0.13 & 1.87 & 0.68 \\
NRM-PZ Mo 167856 & 56 & 35 & 31 & 7 & 19 & 12 & 14 & 1.60 & 0.13 & 1.58 & 0.55 \\
NRM-PZ Mo 167857 & 52 & 39 & 32 & 6 & 25 & 13 & 16 & 1.33 & 0.12 & 1.92 & 0.62 \\
NRM-PZ Mo 167858 & 54 & 38 & 35 & 7 & 32 & 19 & 18 & 1.42 & 0.13 & 1.68 & 0.65 \\
Range & $52-81$ & $35-48$ & $31-43$ & $6-8$ & $19-36$ & $12-21$ & $14-18$ & $1.33-1.69$ & $0.09-0.13$ & $1.58-2.40$ & $0.46-0.68$ \\
Mean & 63.66 & 40.83 & 36.33 & 7.17 & 29 & 16 & 16 & 1.55 & 0.11 & 1.85 & 0.58 \\
\hline
\end{tabular}

join ventral margin in obtuse angle. Ventral margin broadly rounded, joining the posterior margin in a rounded angle. Postero-dorsal margin slightly concave to straight. Posterior end slightly gaping. Umbonal area wide and slightly convex. Beaks subterminal, situated approximately one-fifth of the total valve length from the anterior end, prosogyrate, and not very prominent. Ornament consisting of sparse tuberculate radial ribs (four to six) separated by wide, concave interspaces (Figure 9C) and crossed by numerous, strong, commarginal ribs, becoming finer, more numerous and closely spaced towards the dorsal side.

Discussion. Although the Sergipe specimens are poorly preserved, they show strong similarities to Pholadomya pedernalis from the Turonian of Texas, USA (Roemer, 1852) in having comparatively few and tuberculate radial ribs, wide interspaces, well-developed and numerous commarginal ribs, a short anterior end, subterminal beaks and a wide umbonal area.

Pholadomya connectans Forbes, 1846, from the Upper Cretaceous of southern India (Forbes, 1846, p. 140, pl. 17, fig. 5) resembles $P h$. (Ph.) pedernalis in having few radial ribs (eight) but differs in its strongly rounded anterior and ventral margins and more prominent and nearly orthogyrate beaks.
Ph. (Procardia) fontannesi Choffat, 1886, from the upper Cenomanian of Algeria (Collignon \& Roman, 1983, p. 105, pl. 15, figs. 3-4), differs in having finer and more numerous radial ribs and in being more inflated and less elongate $(\mathrm{L} / \mathrm{H}=$ 1.07 as opposed to 1.39 on average for the Sergipe specimens; Table 6). According to Barber (1958, p. 29), Ph. nauliensis Cox, 1952, from the Campanian of Ghana (Cox, 1952, p. 28 , pl. 2, fig. 7) can be easily distinguished from $P h .(P h$. pedernalis by the less anteriorly located umbonal area.

Abbass (1962, p. 161-162) discussed the differences between Pholadomya (Ph.) pedernalis and other European and American pholadomyid species such as Ph. parvula Roemer, 1846, and Ph. papyracea Meek \& Hayden, 1862, described by Stanton (1894).

Occurrence. Cenomanian of Sergipe, Brazil (this study); Cenomanian-Turonian of the Sinai Peninsula and the Eastern Desert, Egypt (e.g. Abdel-Gawad et al., 2004; El Qot, 2006; Mekawy, 2007; Mekawy \& Abu-Zied, 2008; Ayoub-Hannaa et al., 2014); Turonian of Texas (Roemer, 1852), Gabon (Dartevelle \& Freneix, 1957), Nigeria (Barber, 1958; Akpan \& Ntekim, 2004), Tunisia (Pervinquière, 1912) and Syria (Blanckenhorn, 1934); also reported from the Aptian of France and Algeria and the "Vraconian" (uppermost Albian) of Texas 
Table 6. Dimensions (mm) of Pholadomya (Pholadomya) pedernalis Roemer, 1852.

\begin{tabular}{lcccccccccc}
\hline Specimen & $\mathrm{L}$ & $\mathrm{H}$ & $\mathrm{W}$ & $\mathrm{AL}$ & $\mathrm{Hs}$ & $\mathrm{nr}$ & $\mathrm{L} / \mathrm{H}$ & $\mathrm{AL} / \mathrm{L}$ & $\mathrm{W} / \mathrm{L}$ \\
\hline NRM-PZ Mo 167860 & 20 & 13 & 11 & 6 & 9 & 6 & 1.54 & 0.30 & 0.55 \\
NRM-PZ Mo 167861 & 22 & 17 & 13 & 4 & 11 & 6 & 1.29 & 0.18 & 0.60 \\
NRM-PZ Mo 167862 & 24 & 18 & 15 & 5 & 13 & 4 & 1.33 & 0.21 & 0.62 \\
Range & $20-44$ & $13-18$ & $11-15$ & $4-6$ & $9-13$ & $4-6$ & $1.29-1.54$ & $0.18-0.30$ & $0.55-0.62$ \\
Mean & 22 & 16 & 13 & 5 & 11 & 5 & 1.39 & 0.23 & 0.69 \\
\hline
\end{tabular}

(Pervinquière, 1912, p. 289) and from the Santonian of the Sinai Peninsula (Ziko et al., 1993, p. 142).

\section{Pholadomya (Pholadomya) sp.}

(Figure 9F)

Material. One composite mould (NRM-PZ Mo 167866) from the lower-middle Turonian of locality Pedra Furada 4, Cotinguiba Formation, Sergipe, Brazil.

Measurements. See Table 7.

Description. Shell medium-sized, elongate-ovate, strongly inequilateral, compressed posteriorly. Antero-dorsal margin slightly convex, higher than postero-dorsal margin, joining anterior margin in rounded angle. Postero-dorsal margin slightly concave. Anterior and posterior margins strongly rounded, joining ventral margin in rounded curves. Ventral margin broad and rounded. Umbonal area moderately convex, wide, situated approximately one-third of the total valve length from the anterior end. Ornament consisting of well-developed, tuberculate radial ribs (five), separated by irregular, smooth and wide interspaces. Radial ribs restricted to posterior flank, situated one-third of the total valve length from the posterior end. Central and anterior parts of shell bearing only commarginal growth lines (Figure 9F).

Discussion. The present specimen differs from the other pholadomyid species described here by its wide and strongly rounded anterior margin, narrow and strongly rounded posterior margin and in possessing few and tuberculate radial ribs separated by wide and smooth interspaces. The radial ribs are restricted to the posterior flank, wheras the rest of the valve surface is covered with commarginal growth lines. The specimen may represent a new species, but more material is needed before its status can be determined.

Pholadomya pedisulcata Stoliczka (1870, p. 81, pl. 4, fig. 1; pl. 1, fig. 2G) from the Upper Cretaceous of India resembles the present specimen in having few but well-developed radial ribs, though restricted to the anterior area (approximately $15 \%$ of the total valve length from the anterior end), and in being much larger $(\mathrm{L}=45 \mathrm{~mm}$ as opposed to $15 \mathrm{~mm}$ for the Sergipe specimen; Table 7) and more elongate.
Occurrence. Turonian of Sergipe, Brazil (this study).

\section{Subgenus Bucardiomya Rollier, 1912}

Type species. Pholadomya bucardium Agassiz, 1842, by subsequent designation of Cox (1969b).

Remarks. The subgenus Bucardiomya is characterized by its tall, subtrigonal shell, sharply pointed, orthogyrate to prosogyrate beaks, truncated posterior margin, and absence of escutcheon and lunule. Ornament consists of radial ribs intersecting with concentric growth lines, forming a reticulate pattern. The Brazilian specimens are incomplete and distorted composite moulds and therefore only tentatively assigned to Bucardiomya.

\section{Pholadomya (Bucardiomya?) sp.}

(Figures 9G-M)

Material. Two composite moulds (NRM-PZ Mo 167867167868) from the lower-middle Turonian of locality São Roque 2, Cotinguiba Formation, Sergipe, Brazil.

Measurements. See Table 8.

Description. Shell small, subtrigonal, equivalved, inequilateral, slightly higher than long $(\mathrm{L} / \mathrm{H}=0.90$ on average; Table 8$)$ and highly inflated $(\mathrm{W} / \mathrm{L}=0.71$ on average). Maximum inflation below umbonal area, sharply diminishing towards posterior side. Valves in anterior view subcordate. Ventral margin strongly rounded, joining anterior and posterior margins in rounded curves. Postero-dorsal margin concave and steeply oblique towards posterior end. Anterodorsal margin slightly convex and higher than postero-dorsal margin. Umbonal area trigonal, narrow, and strongly convex. Beaks prominent, sharply pointed, slightly prosogyrate to orthogyrate, situated approximately one-third of the total valve length from the anterior end, with moderately welldeveloped posterior umbonal ridge. Escutcheon and lunule lacking (Figure 9I). Ornament consisting of 8-12 radial ribs crossed by thick commarginal ribs. Numerous fine, radial and commarginal elements intersecting towards the umbonal area, forming reticulate pattern. Further away from the

Table 7. Dimensions (mm) of Pholadomya (Pholadomya) sp.

\begin{tabular}{|c|c|c|c|c|c|c|c|c|}
\hline Specimen & $\mathrm{L}$ & $\mathrm{H}$ & $\mathrm{W}$ & $\mathrm{AL}$ & $\mathrm{nr}$ & $\mathrm{L} / \mathrm{H}$ & $\mathrm{AL} / \mathrm{L}$ & $\mathrm{W} / \mathrm{L}$ \\
\hline NRM-PZ Mo 167866 & 15 & 13 & -- & 6 & 5 & 1.15 & 0.33 & -- \\
\hline
\end{tabular}


umbonal area, radial and commarginal ribs becoming thicker, irregularly distributed and separated by wide interspaces occupied by intercalatories (Figures 9G,K).

Discussion. The two specimens differ from the other pholadomyid species described here in having sharply pointed and orthogyrate beaks, thick and irregular commarginal ribs with intercalatories (Figures 9H,K-L), strongly rounded anterior and ventral margins, and in lacking a lunule and escutcheon. Because the specimens are distorted composite moulds, a species determination is not possible.

The Sergipe specimens closely resemble Pholadomya distorta Anderson, 1938, described from the Lower

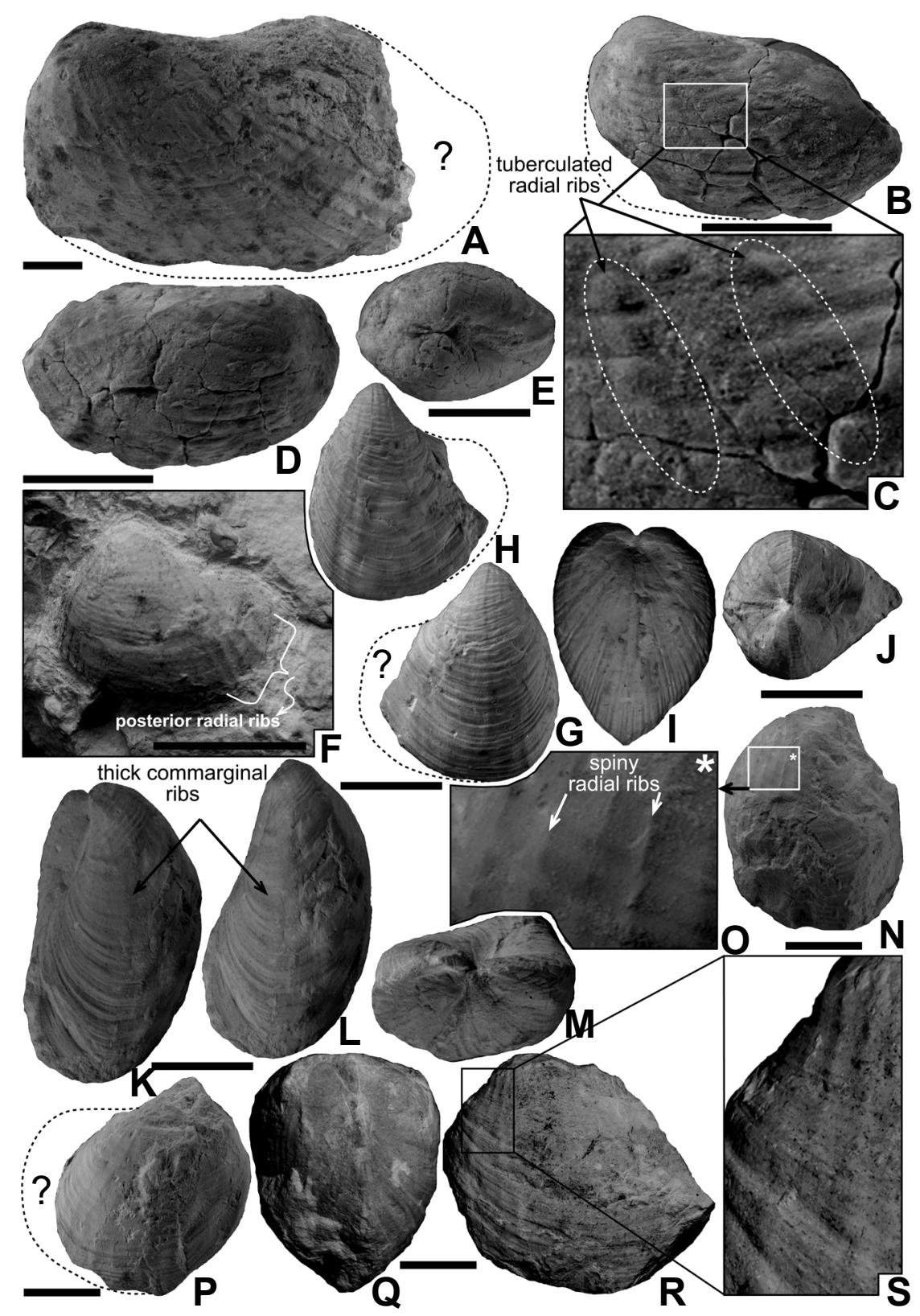

Figure 9. A, Pholadomya (Pholadomya) occidentalis Morton, 1833; left lateral view of incomplete composite mould from the lower-middle Turonian of locality Pedra Furada 5 (NRM-PZ Mo 167854). B-E, Pholadomya (Pholadomya) pedernalis Roemer, 1852 from the middle-upper Cenomanian. B, incomplete distorted composite mould of left valve; C, close-up view of left valve showing tuberculate radial ribs; $\mathbf{D}$, Side view of right valve; locality Cruzes 8 (NRM-PZ Mo 167860); E, dorsal view of articulated valves; locality Timbó 4 (NRM-PZ Mo 167861). F, Pholadomya (Pholadomya) sp.; left lateral view of composite mould from the lower-middle Turonian of locality Pedra Furada 4 (NRM-PZ Mo 167866). G-M, Pholadomya (Bucardiomya?) sp. from the lower-middle Turonian. G, right lateral view; $\mathbf{H}$, left lateral view; I, anterior view of articulated valves with thick anterior commarginal ribs; J, dorsal view of articulated composite mould showing narrow, sharply pointed beaks; locality São Roque 2 (NRM-PZ Mo 167867); K, posterior view of articulated valves; L, right lateral view of distorted composite mould showing thick, irregular growth rugae; $\mathbf{M}$, dorsal view showing sharply pointed beaks with shallow anterior depression; locality São Roque 2 (NRM-PZ Mo 167868). N-P, Pholadomya (Procardia) vignesi Lartet, 1877, from the middle Cenomanian of locality Jericó 3 (NRM-PZ Mo 167869). N, left lateral view of incomplete composite mould; $\mathbf{O}$, close-up showing spinose radial ribs near the antero-dorsal area of left valve; $\mathbf{P}$, side view of right valve; $\mathbf{Q}-\mathbf{S}$, Pholadomya (Procardia) sp. from the lower-middle Turonian of locality Laranjeiras 22 (NRM-PZ Mo 167870). Q, anterior view of articulated valves; R, lateral view of incomplete left valve; $\mathbf{S}$, close-up showing fine growth lines crossed by tuberculate radial ribs along the dorsal area. Both radial ribs and growth lines increase in strength ventrally. All specimens from the Cotinguiba Formation of the Sergipe Basin, Brazil. Scale bars $=10 \mathrm{~mm}$. 
Cretaceous of California (Anderson, 1938, p. 117, pl. 3, figs. 9,10 ) in general outline and in having orthogyrate and sharly pointed beaks but differ in being smaller $(\mathrm{L}=23.5 \mathrm{~mm}, \mathrm{H}=$ $26 \mathrm{~mm}, \mathrm{~W}=16 \mathrm{~mm}$ (Table 8 ) as opposed to $\mathrm{L}=35 \mathrm{~mm}, \mathrm{H}$ $=40 \mathrm{~mm}, \mathrm{~W}=27 \mathrm{~mm}$ on average) and showing faint radial ribs along the dorsal region (reticulate pattern) that disappear ventrally. According to Anderson (1938), Ph. distorta has well-developed commarginal ribs and lacks radial ribs. $P h$. esmarkii (Nilsson, 1827) differs in possessing less developed commarginal ribs and more numerous, regular radial ribs with two well-developed anterior ventral keels with a sulcus in between. Ph. decussata (Mantell, 1822) from the Upper Cretaceous of England (Mantell, 1822, p. 125, pl. 25, fig. 3) differs in having a posteriorly truncated, incurved umbonal area, a shallow anterior cavity, and in being larger and more inflated.

Occurrence. Turonian of Sergipe, Brazil (this study).

\section{Subgenus Procardia Meek, 1871}

Type species. Isocardia? hodgei Meek, 1871, by monotypy.

Remarks. The subgenus Procardia is characterized by highly inflated valves, a strongly rounded posterior margin, a narrow and slightly convex anterior margin, tuberculate radial ribs, and strongly prosogyrate beaks.

\section{Pholadomya (Procardia) vignesi Lartet, 1877}

(Figures 9N-P)

1877 Pholadomya vignesi: Lartet, p. 126, pl. 11, fig. 9.

1912 Pholadomya vignesi Lartet: Pervinquière, p. 290, pl. 21, figs. 8-9.

1917 Pholadomya vignesi Lartet: Fourtau, p. 93, pl. 7, fig. 6. 1928 Pholadomya vignesi Lartet: Shalem, p. 83, pl. 4, fig. 14. ?1957 Pholadomya cf. vignesi Lartet: Dartevelle \& Freneix, p. 213 , pl. 33, fig. 5 .

1962 Pholadomya vignesi Lartet: Abbass, p. 157, pl. 24, fig. 8, non fig. 7.

1981 Pholadomya (Procardia) vignesi Lartet: Collignon \& Roman., p. 82, pl. 2, figs. 3-4.

2002 Pholadomya vignesi Lartet: Abdel-Gawad \& Gameil, p. 97, pl. 4, fig. 11.

2006 Pholadomya (Pholadomya) vignesi Lartet: El Qot, p. 91, pl. 18 , fig. 8.

?2006 Pholadomya sp.? Perrilliat et al., p. 104, figs. 29-30.

2012 Pholadomya (Pholadomya) vignesi Lartet: Benyoucef et al., pl. 3, fig. 14.
Material. One incomplete composite mould (NRM-PZ Mo 167869) from the middle Cenomanian of locality Jericó 3 , Cotinguiba Formation, Sergipe, Brazil.

Measurements. See Table 9.

Description. Shell medium-sized, elongate-ovate, equivalved, inequilateral, slightly longer than high, highly inflated $(\mathrm{W} / \mathrm{L}=0.81$; Table 9) with maximum inflation below umbonal area. Anterior area short, higher than posterior area. Anterior margin convex, joining ventral margin in rounded angle. Ventral margin strongly convex. Postero-dorsal margin straight, gradually sloping towards posterior end. Umbonal area wide, moderately convex, situated anteriorly. Beaks strongly prosogyrate. Ornament consisting of well-developed commarginal ribs separated by narrow interspaces and crossed by seven widely spaced radial ribs. Ribs tuberculate, well developed in middle and dorsal parts and separated by wide, smooth, concave interspaces (Figure 90).

Discussion. Pholadomya (Procardia) vignesi is readily distinguished by its comparatively few radial ribs, thick and well-developed commarginal ribs, highly inflated valves, wide umbonal area and rounded margins.

Pholadomya (Bucardiomya?) sp. described above resembles $P h$. (P.) vignesi in having well-developed commarginal ribs and rounded margins but differs in being less inflated and in having a narrow trigonal umbonal area and more numerous radial ribs (13). Ph. incurvata Riedel, 1933, from the Cenomanian of Cameroon (Riedel, 1933, p. 65, pl. 5, fig. 2) differs in being more elongate and in having a large anterior area. In addition, the radial ribs of Ph. incurvata are restricted to the middle part of the valves. $P h$. (Ph.) pedernalis Roemer, 1852 has approximately the same number of radial ribs (five) but differs in being much more elongate $(\mathrm{L} / \mathrm{H}=1.43$ as opposed to 0.90 ; Table 9) and in having less prominent and subterminal beaks and less developed commarginal ribs. Ph. aff. pedernalis from the lower Turonian of Nigeria (Barber, 1958, p. 28, pl. 8, fig. 5; pl. 9, figs. 8-9) is closer to Ph. vignesi than to $P h$. $(P h$. pedernalis. Ph. umbonata Roemer, 1841, from the Upper Cretaceous of Germany (Roemer, 1841, pl. 10, fig. 6) differs in being larger $(\mathrm{L}=75 \mathrm{~mm}, \mathrm{H}=64 \mathrm{~mm}$ as opposed to $\mathrm{L}=27 \mathrm{~mm}$, $\mathrm{H}=30 \mathrm{~mm}$ ) and in having numerous, fine, commarginal ribs and the radial ribs restricted to the anterior flank of the valves. Blanckenhorn (1934, p. 261) distinguished Ph. vignesi and $P h$. syriaca Conrad, 1852, from the Cenomanian of Syria (Conrad, 1852, p. 231, pl. 2, fig. 17) on the basis of number and strength of radial ribs (7-14 sharp ribs in $P h$. syriaca and 16-24 in $P h$. vignesi). However, Vokes (1941, p. 9) regarded Ph. syriaca and $P h$. vignesi as probable varieties of the same species. Ph. (Procardia) fontannesi Choffat, 1886, from the upper

Table 8. Dimensions (mm) of Pholadomya (Bucardiomya?) sp.

\begin{tabular}{lccccccccccc}
\hline Specimen & $\mathrm{L}$ & $\mathrm{H}$ & $\mathrm{W}$ & $\mathrm{AL}$ & $\mathrm{Hs}$ & $\mathrm{Ws}$ & $\mathrm{nr}$ & $\mathrm{L} / \mathrm{H}$ & $\mathrm{AL} / \mathrm{L}$ & $\mathrm{Hs} / \mathrm{Ws}$ & $\mathrm{W} / \mathrm{L}$ \\
\hline NRM-PZ Mo 167867 & 20 & 22 & 16 & 7 & 12 & 4 & 12 & 0.91 & 0.35 & 3.00 & 0.80 \\
NRM-PZ Mo 167868 & 27 & 30 & 17 & -- & 14 & --- & 8 & 0.90 & --- & -- & 0.63 \\
Range & $20-27$ & $22-30$ & $16-17$ & 7 & $12-14$ & 4 & $8-12$ & $0.90-0.91$ & 0.35 & 3.00 & $0.63-0.80$ \\
Mean & 23.50 & 26 & 16 & 7 & 13 & 4 & 13 & 0.90 & 0.35 & 3.00 & 0.71 \\
\hline
\end{tabular}


Cenomanian of Algeria (Collignon \& Roman, 1983, pl. 15, figs. 3-4) differs in having well-developed, dorsal commarginal ridges. Ph. coxi Abbass, 1962, from the Cenomanian of the Sinai Peninsula, Egypt (Abbass, 1962, p. 158, pl. 24, fig. 3), differs in having less developed commarginal ribs, a trigonal outline and a narrow and truncated posterior margin.

Occurrence. Cenomanian of Sergipe, Brazil (this study), the Dead Sea area (Lartet, 1877), Palestine (Shalem, 1928), Syria (Blanckenhorn, 1934), Egypt (e.g. Fourtau, 1917; AbdelGawad \& Gameil, 2002; El Qot, 2006), Tunisia (Pervinquière, 1912) and Algeria (Collignon \& Roman, 1983; Busson et al., 1999; Benyoucef et al., 2012); Turonian of Jordan (Perrilliat et al. 2006); "Senonian" of Gabon (Dartevelle \& Freneix, 1957).

\section{Pholadomya (Procardia) sp.}

(Figures 9Q-S)

Material. Two incomplete, composite moulds (NRM-PZ Mo 167870-167871) from the lower-middle Turonian of localities Laranjeiras 21 and 22, Cotinguiba Formation, Sergipe, Brazil. Measurements. See Table 10.

Description. Shell medium-sized, elongate-ovate, inequilateral, slightly equivalved and moderately inflated $(\mathrm{W} / \mathrm{L}=0.59$; Table 10$)$. Length and height nearly equal $(\mathrm{L} / \mathrm{H}$ $=1.06$ ). Anterior side of both valves subcordate. Anterior margin truncated. Ventral margin rounded. Umbonal area wide and convex; no lunule. Ornament consisting of sparse, tuberculate, radial ribs, becoming finer dorsally and crossed by commarginal ribs forming a reticulate pattern near umbonal area. Growth lines fine along dorsal area, thicker and more irregular ventrally (Figures 9R,S).

Discussion. The two specimens are similar in general outline and ornament to Pholadomya decussata (Mantell, 1822) from the Upper Cretaceous of Germany (Holzapfel, 1889, p. 154, pl. 14, figs. 3-4) and to Ph. cordata Tate, 1865, from the Upper Cretaceous of England (Woods, 1909, p. 253, pl. 42, fig. 2). However, Ph. decussata is larger, highly inflated and has sharp, pointed, strongly incurved beaks with a welldeveloped anterior umbonal keel extending from the umbonal area to the antero-ventral margin, forming a shallow to deep anterior depression.

Occurrence. Turonian of Sergipe, Brazil (this study).

\section{Homomya Agassiz, 1843}

Type species. Mactra (Lutraria) gibbosa J. Sowerby, 1813, by subsequent designation of Herrmannsen (1847).
Homomya bisinuosa (White, 1887)

(Figures 10A-C)

1887 Myacites bisinuosus (sp. nov.): White, p. 104, pl. 7, figs. 6-7.

1887 Glycimeris rathbuni (sp. nov.): White, p. 110, pl. 7, figs. $3,4(?)$.

1937 Homomya bisinuosa (White): Maury, p. 79, pl. 10, figs. 15-16.

1937 Panopea rathbuni (White): Maury, p. 83, pl. 9, figs. 12(?), 13.

1999 Panopea (Panopea) rathbuni (White): Seeling, p. 132133 (pars, cf. Appendix 1 herein), pl. 6, fig. 4, non figs. 2-3. 2014 Homomya rathbuni (White 1887): Ayoub-Hannaa et al., p. 127 , pl. 12 , fig. 8 .

Material. Five composite moulds (NRM-PZ Mo 167872167876) from the upper Cenomanian-lower Turonian of localities Japaratuba 6 and 16, the lower Turonian of Sergipe 5 and the upper Turonian of Cajaíba 7, Cotinguiba Formation, Sergipe, Brazil.

Measurements. See Table 11.

Description. Shell large, elongate-ovate, strongly inequilateral, equivalved, posteriorly elongate and moderately inflated $(\mathrm{W} / \mathrm{L}=0.49$ on average; Table 11). Inflation decreasing gradually towards posterior end. Antero-ventral and postero-dorsal margins slightly gaping. Antero-dorsal margin short, straight to slightly concave, higher than posterodorsal margin and joining anterior margin in nearly right angle. Postero-dorsal margin slightly concave. Anterior and posterior margins rounded, joining ventral margin in rounded angles. Escutcheon narrow, elongate and moderately deep (Figure 10C). Umbonal area broadly arched and slightly convex. Beaks less prominent, slightly prosogyrate, elevated above hinge, and situated one-fourth of the total valve length from the anterior end. Ornament consisting of thick, undulating commarginal ribs (Figure 10A). Radial ribs absent. Commarginal ribs less developed towards dorsal side.

Discussion. The species Homomya bisinuosa is here assigned to the genus Homomya on the basis of its less prominent beaks, narrow and deep escutcheon, moderately inflated valves and commarginal ribs. Although the present specimens show strong similarities in outline, size, and ornament to $H$. bisinuosa, as figured by White (1887) and Maury (1937), they differ in having a wider umbonal area.

Homomya bisinuosa (White, 1887) from the Albian of Sergipe (White, 1887; Maury, 1937) closely resembles

Table 9. Dimensions (mm) of Pholadomya (Procardia) vignesi Lartet, 1877.

\begin{tabular}{lcccccccc}
\hline Specimen & L & H & W & AL & nr & L/H & AL/L & W/L \\
\hline NRM-PZ Mo 167869 & 27 & 30 & 22 & 12 & 7 & 0.90 & 0.44 & 0.81 \\
\hline
\end{tabular}

Table 10. Dimensions (mm) of Pholadomya (Procardia) sp.

\begin{tabular}{lccccccc}
\hline Specimen & L & H & W & AL & L/H & AL/L & W/L \\
\hline NRM-PZ Mo 167870 & 49 & 46 & c. 29 & 14 & 1.06 & 0.28 & 0.59 \\
\hline
\end{tabular}


H. rathbuni in having less prominent beaks, moderately inflated valves $(\mathrm{W} / \mathrm{L}=0.49$ on average $)$ and irregular and strong commarginal ribs, but differs in being less elongate and in having subterminal beaks. These differences are not considered sufficient enough to separate the species. H. refugium (White, 1887), from the middle Albian of Sergipe (White, 1887, p. 103, pl. 7, fig. 8) resembles $H$. bisinuosa in having a wide umbonal area and approximately the same size $(\mathrm{L}=72 \mathrm{~mm}, \mathrm{H}=42 \mathrm{~mm}$ and $\mathrm{L}=65.5 \mathrm{~mm}, \mathrm{H}=40.5 \mathrm{~mm}$ on average, respectively) but differs in being slightly more elongate $(\mathrm{L} / \mathrm{H}=1.71 \mathrm{vs} .1 .61 \mathrm{on}$ average for $H$. bisinuosa; Table 11) and in having a narrow and rounded posterior margin, blunt anterior margin and a regularly convex ventral margin.

Occurrence. Albian (White, 1887; Maury, 1937) and Cenomanian-Turonian (Seeling, 1999; this study) of Sergipe, Brazil; Turonian of the Sinai Peninsula, Egypt (Ayoub-Hannaa et al., 2014).

\section{Homomya brasiliensis (White, 1887)}

(Figures 10D-H)

1887 Glycimeris brasiliensis (sp. nov.): White, p. 111, pl. 7 , figs. 1-2.

1937 Panopea brasiliensis (White): Maury, p. 81, pl. 11, figs. 11-12.

v1999 Panopea (Panopea) rathbuni (White, 1887): Seeling, pp. 132-133 (pars, cf. Appendix 1 herein), pl. 6, figs. 2-3, non fig. 4.

v1999 Panopea sp.: Seeling, p. 134 (pars, cf. Appendix 1 herein).

Material. Three composite and internal moulds (NRM-PZ Mo 167877-167879) from the upper Cenomanian-lower Turonian of locality Japaratuba 16, Cotinguiba Formation, Sergipe, Brazil.

Measurements. See Table 12.

Description. Shell large, oblong to subquadrate, strongly inequilateral, equivalved, moderately inflated, posteriorly elongate $(\mathrm{L} / \mathrm{H}=1.73-2.02$; Table 12$)$. Anterior margin short, blunt, located below hinge. Posterior margin wide, ovate, regularly rounded, joining ventral margin in rounded curve. Antero-ventral and posterior margins slightly gaping. Ventral margin slightly curved to straight, parallel to hinge line. Antero-dorsal margin short, concave, joining anterior margin in acute angle. Postero-dorsal margin straight to slightly concave. Escutcheon narrow, elongate and shallow. Umbonal area broad and moderately convex. Beaks less prominent, slightly prosogyrate, terminal to subterminal $(\mathrm{Al} / \mathrm{L}=0.16$ on average; Table 12). Valve surface bearing numerous fine commarginal ribs (Figure 10D).

Discussion. Homomya brasiliensis is readily recognized by its very elongate valves $(\mathrm{L} / \mathrm{H}=1.87$ on average; Table 12$)$, terminal to subterminal beaks, straight postero-dorsal margin running nearly parallel to the ventral margin and being higher than the antero-dorsal side, blunt anterior end, and by having numerous fine commarginal ribs. According to Seeling (1999, p. 133) Homomya rathbuni and $H$. brasiliensis are similar and occur in the same stratigraphic interval and therefore synonyms. $H$. brasiliensis indeed resembles $H$. rathbuni (= Homomya bisinuosa herein; see above) in size, curvature of umbonal area, and in having a small shallow escutcheon, but it differs in being much more elongate $(\mathrm{L} / \mathrm{H}=1.87$ on average as opposed to 1.66) and in having terminal to subterminal beaks, a blunt anterior end, and numerous, fine, commarginal ribs.

Occurrence. Albian (White, 1887; Maury, 1937) and Cenomanian-Turonian (this study) of Sergipe, Brazil.

Family PLEUROMYIDAE Zittel, 1895

$$
\text { Pleuromya Agassiz, } 1842
$$

Type species. Mya gibbosa J. de C. Sowerby, 1923, by monotypy.

Pleuromya ligeriensis (d'Orbigny, 1845)

(Figures 10I,J)

1845 Pholadomya ligeriensis d'Orbigny, 1844 [sic]: d'Orbigny, p. 355, pl. 363, figs. 8-9.

Table 11. Dimensions (mm) of Homomya bisinuosa (White, 1887).

\begin{tabular}{lcccccccc}
\hline Specimen & L & H & W & AL & Hs & L/H & AL/L & W/L \\
\hline NRM-PZ Mo 167872 & 69 & 43 & 34 & 18 & 30 & 1.60 & 0.26 & 0.49 \\
NRM-PZ Mo 167873 & 62 & 38 & 31 & 15 & 22 & 1.63 & 0.24 & 0.50 \\
Range & $62-69$ & $38-43$ & $31-34$ & $15-18$ & $22-30$ & $1.60-1.63$ & $0.24-0.26$ & $0.49-0.50$ \\
Mean & 65.50 & 40.50 & 32.50 & 16.5 & 26 & 1.61 & 0.25 & 0.49 \\
\hline
\end{tabular}

Table 12. Dimensions (mm) of Homomya brasiliensis (White, 1887).

\begin{tabular}{lcccccccc}
\hline Specimen & L & H & W & AL & Hs & L/H & AL/L & W/L \\
\hline NRM-PZ Mo 167877 & 76 & 44 & 40 & 13 & 24 & 1.73 & 0.17 & 0.52 \\
NRM-PZ Mo 167878 & 71 & 35 & 33 & 11 & 21 & 2.02 & 0.15 & 0.46 \\
Range & $71-76$ & $35-44$ & $33-40$ & $11-13$ & $21-24$ & $1.73-2.02$ & $0.15-0.17$ & $0.46-0.52$ \\
Mean & 73.5 & 39.5 & 36.50 & 12 & 22.50 & 1.87 & 0.16 & 0.49 \\
\hline
\end{tabular}




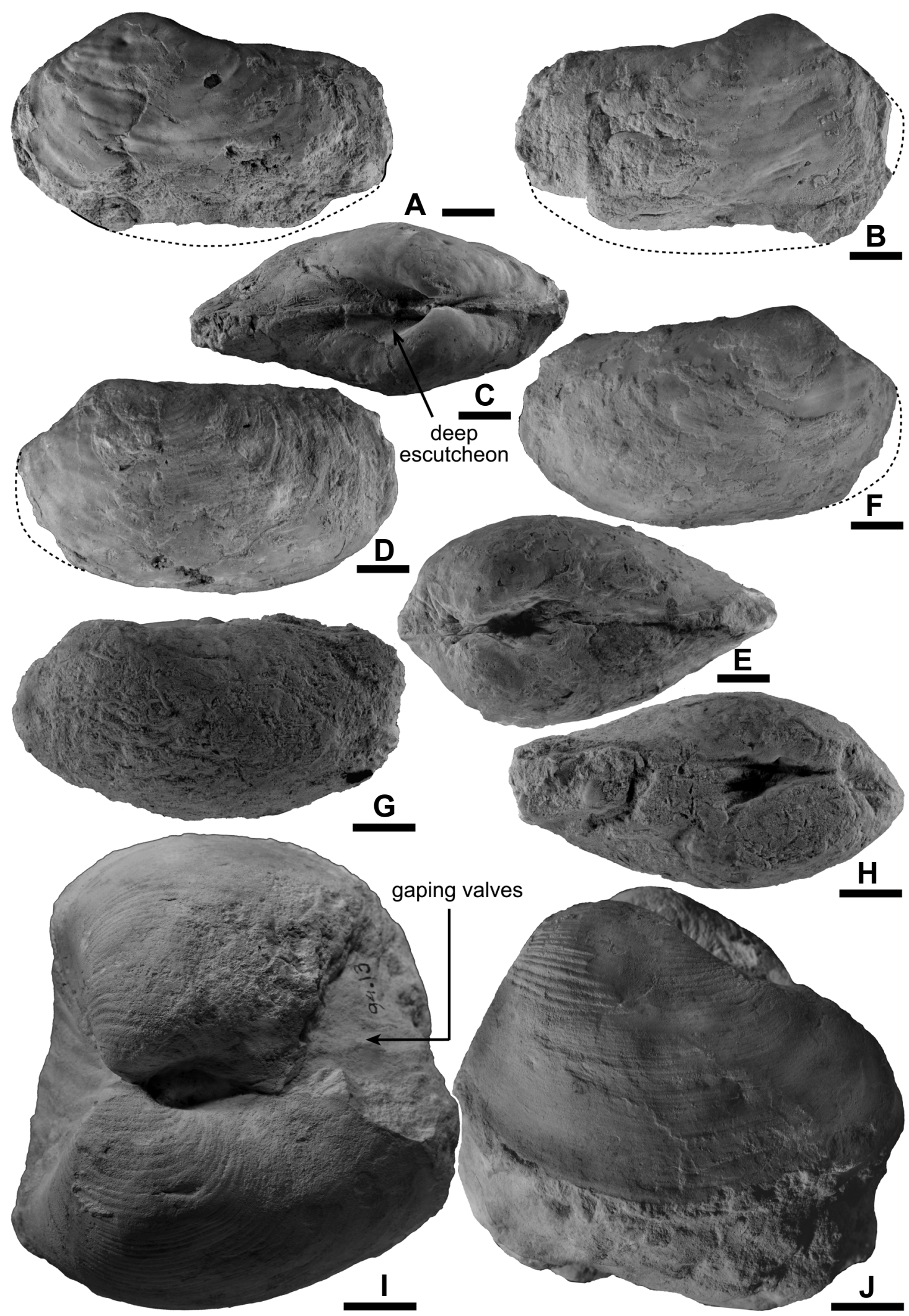

Figure 10. A-C, Homomya bisinuosa (White, 1887) from the upper Cenomanian-lower Turonian of locality Japaratuba 6 (NRM-PZ Mo 167872). A, left lateral view; B, side view of right valve; C, dorsal view showing depressed umbonal area and deep escutcheon. D-H, Homomya brasiliensis (White, 1887) from the upper Cenomanian-lower Turonian of locality Japaratuba 16. D, side view of left valve; composite mould of articulated specimen; E, Dorsal view of both valves; F, right lateral view (NRM-PZ Mo 167877); G, left lateral view; of internal mould showing the expanded posterior area; $\mathbf{H}$, dorsal view of both valves showing the subterminal beaks and highly inflated valves (NRM-PZ Mo 167878). I-J, Pleuromya ligeriensis (d'Orbigny, 1845) from the lower-middle Turonian of locality Pedra Furada 3 (NRM-PZ Mo 167880). I, dorsal view showing gaping valves; J, left lateral view. All specimens from the Cotinguiba Formation of the Sergipe Basin, Brazil. Scale bars $=10 \mathrm{~mm}$. 
?1862 Pholadomya Molli H. Coq.: Coquand, p. 189, pl. 6, figs. 6-7.

1887 Homomya profunda (sp. nov.): White, p. 105, pl. 7, fig. 5. 1912 Liopistha (Psilomya) cf. L. ligeriensis (d'Orbigny): Pervinquière, p. 292, pl. 20, fig. 22.

1937 Homomya profunda White: Maury, p. 77, pl. 10, fig. 13. 1958 Liopistha ligeriensis (d'Orbigny): Barber, p. 29, pl. 9, fig. 7.

1997 Pleuromya ligeriensis (d'Orbigny): Smettan, p. 132, pl. 7, figs. 12-13.

non 1999 Liopistha (Psilomya) ligeriensis (d'Orbigny): Seeling, p. 136, pl. 6, figs. 5-7 [= Liopistha (Sergipemya) alta (Roemer, 1852)].

1999 Liopistha (Psilomya)? cf. alta: Seeling, p. 137 (pars, cf. Appendix 1 herein).

non 2011 Liopistha (Psilomya) ligeriensis (d'Orbigny, 1945 [sic]): Andrade \& Santos, p. 233, figs. 2.3-4 [= Megaporomya reymenti Ayoub-Hannaa et al., 2013].

2014 Pleuromya ligeriensis (d'Orbigny 1845): Ayoub-Hannaa et al., p. 128, pl. 13, fig. 1.

Material. Three composite moulds (NRM-PZ Mo 167880167882) from the upper Cenomanian-lower Turonian of locality Japaratuba 6 and the lower-middle Turonian of Pedra Furada 3, Cotinguiba Formation, Sergipe, Brazil.

Measurements. See Table 20.

Description. Shell medium-sized, elongate-ovate, equivalved, strongly inequilateral, elongate posteriorly, and highly inflated. Anterior margin short, truncated, joining the ventral margin in nearly right angle. Posterior margin rounded, joining ventral margin in rounded curve. Ventral margin wide and faintly convex. Postero-dorsal margin straight to slightly concave. Umbonal area wide and inflated. Beaks prominent, slightly incurved anteriorly. Ligament external. Anterior umbonal ridge moderately well developed, extending from umbonal area to middle of anterior end, forming wide, concave, anterior cavity (Figure 10I). Numerous fine, commarginal ribs separated by irregular interspaces; ribs becoming stronger and separated by narrower interspaces towards umbonal area (Figure 10J).

Discussion. Pholadomya molli Coquand, 1862, from the Turonian of Algeria resembles Pleuromya ligeriensis (d'Orbigny) in possessing numerous, fine, commarginal ribs and a well-developed anterior umbonal ridge with a deep anterior depression, but differs in its narrow and terminal beaks. White (1887) described the new species Homomya profunda from the middle Albian of Sergipe, which closely resembles $P$. ligeriensis in outline and ornament but is smaller $(\mathrm{L}=36 \mathrm{~mm}, \mathrm{H}=30 \mathrm{~mm}, \mathrm{~W}=22 \mathrm{~mm}$; P. ligeriensis:
$\mathrm{L}=57 \mathrm{~mm}, \mathrm{H}=49 \mathrm{~mm}, \mathrm{~W}=c .44 \mathrm{~mm}$ on average; Table 13). Following Pervinquière (1912) and Barber (1958), $H$. profunda is here considered a junior synonym of P. ligeriensis. P. elongata (Roemer, 1841) from the Upper Cretaceous of Germany (Roemer, 1841, p. 75, pl. 10, fig. 5) differs from $P$. ligeriensis in being less inflated and in having a more extended posterior area and a narrow umbonal area.

The specimens described by Andrade \& Santos (2011, p. 233, fig. 2.3-4) as Liopistha (Psilomya) ligeriensis from the Turonian of Sergipe (locality Mata 11) are poorly preserved and differ from the specimens described here in being larger $(\mathrm{L}=65-112 \mathrm{~mm}, \mathrm{H}=64-102 \mathrm{~mm})$, more inflated, and in having less prominent beaks. Ayoub-Hannaa et al. (2013) referred the specimens of Andrade \& Santos (2011) to the new genus and new species Megaporomya reymenti.

Occurrence. Aptian(?)-Cenomanian of Germany (Smettan, 1997); Cenomanian of Tunisia (Pervinquière, 1912); Cenomanian-Turonian of Algeria (Coquand, 1862); Cenomanian of Egypt; Cenomanian-Turonian of Sergipe, Brazil (this study); Turonian of France (d'Orbigny, 1845) and Nigeria (Barber, 1958).

\section{Pleuromya servesensis Choffat, 1902 (Figures 11A-E)}

1902 Pleuromya servesensis: Choffat, p. 132, pl. 9, figs. 1-3. 1928 Homomya sp.: Adkins, p. 140, pl. 15, fig. 2.

?1958 Liopistha $\mathrm{cf}$. servesensis (Choffat): Barber, p. 29, pl. 9, fig. 13.

v1999 Panopea (Panopea) rathbuni (White, 1887): Seeling, p. 132-133 (pars, cf. Appendix 1 herein); non pl. 6, figs. 2-4. v1999 Liopistha (Psilomya) concentrica Stanton, 1893: Seeling, p. 135 (pars, cf. Appendix 1 herein).

v1999 Panopea sp.: Seeling, p. 134 (pars, cf. Appendix 1 herein).

?2004 Pleuromya sp. Akpan \& Ntekim, p. 30, figs. 6o-p.

Material. Five composite moulds (NRM-PZ Mo 167883167887) from the upper Cenomanian of locality Jardim 31 and the upper Cenomanian-lower Turonian of Japaratuba 6 and 11, Cotinguiba Formation, Sergipe, Brazil.

Measurements. See Table 20.

Description. Shell large, elongate-ovate to oblong $(\mathrm{L} / \mathrm{H}=1.52$ on average; Table 14), strongly inequilateral, nearly equivalved, inflated. Maximum inflation slightly below umbonal area $(\mathrm{W} / \mathrm{L}=0.47$ on average; Table 14), decreasing gradually towards posterior end. Postero-dorsal margin straight to slightly concave. Posterior margin rounded, joining ventral margin in rounded angle. Anterior margin

Table 13. Dimensions (mm) of Pleuromya ligeriensis (d'Orbigny, 1845).

\begin{tabular}{|c|c|c|c|c|c|c|c|}
\hline Specimen & $\mathrm{L}$ & $\mathrm{H}$ & W & $\mathrm{AL}$ & $\mathrm{L} / \mathrm{H}$ & $\mathrm{AL} / \mathrm{L}$ & $\mathrm{W} / \mathrm{L}$ \\
\hline NRM-PZ Mo 167879 & 62 & 48 & c. 44 & 13 & 1.29 & 0.21 & c. 0.71 \\
\hline NRM-PZ Mo 167880 & 52 & 50 & -- & 16 & 1.04 & 0.31 & -- \\
\hline Range & $52-62$ & $48-50$ & c. 44 & $13-16$ & $1.04-1.29$ & $0.21-0.31$ & c. 0.71 \\
\hline Mean & 57 & 49 & c. 44 & 14.50 & 1.16 & 0.26 & c. 0.71 \\
\hline
\end{tabular}


Table 14. Dimensions (mm) of Pleuromya servesensis Choffat, 1901.

\begin{tabular}{lccccccc}
\hline Specimen & L & H & W & AL & L/H & AL/L & W/L \\
\hline NRM-PZ Mo 167883 & 38 & 29 & 21 & 14 & 1.31 & 0.37 & 0.44 \\
NRM-PZ Mo 167884 & 56 & 34 & 25 & 17 & 1.65 & 0.30 & 0.45 \\
NRM-PZ Mo 167885 & 48 & 30 & 27 & 14 & 1.60 & 0.29 \\
NRM-PZ Mo 167886 & 42 & 27 & 18 & 15 & 1.48 & 0.38 & 0.56 \\
NRM-PZ Mo 167887 & 44 & 28 & 22 & 12 & 1.57 & 0.27 & 0.42 \\
Range & $38-56$ & $27-34$ & $18-27$ & $12-17$ & $1.31-1.65$ & $0.27-0.38$ & $0.42-0.56$ \\
Mean & 45.60 & 29.60 & 22.60 & 14.40 & 1.52 & 0.32 & 0.47 \\
\hline
\end{tabular}

truncated, joining wide and slightly convex ventral margin in nearly right angle. Posterior end slightly gaping; no lunule. Umbonal area wide and highly inflated. Beaks less prominent, prosogyrate, situated one-third of the total valve length from the anterior end. Ornament consisting of well-developed irregular commarginal ribs separated by wide interspaces (Figures 11A,B).

Discussion. Barber (1958) assigned Pleuromya servesensis to the genus Liopistha Meek, 1864. However, radial ribs, which are an important feature in Liopistha (see below), are absent in $P$. servesensis. P. servesensis is characterized by irregular, thick growth rugae and a wide umbonal area. $P$. congoensis Dartevelle \& Freneix, 1957, from the Maastrichtian of BasCongo (Democratic Republic of the Congo) (Dartevelle \& Freneix, 1957, p. 208, pl. 32, figs. 9,10; pl. 33, figs. $1,2)$ resembles the Sergipe specimens in ornament and in having elongate-ovate to oblong valves but differs in being less elongate $(\mathrm{L} / \mathrm{H}=1.33$ as opposed to 1.52 on average for the Sergipe specimens; Table 14), more inflated (W/L $=0.64$ as opposed to 0.47 on average) and in having finer commarginal ribs. P. luynesi (Lartet, 1877) from the Upper Cretaceous of Palestine (Lartet, 1877, p. 125, pl. 11, figs. 7,8) and the Coniacian of Egypt (Greco, 1919, p. 158, pl. 17, figs. 23,24) differs in having numerous, fine, commarginal ribs, a rounded anterior margin and a nearly central umbonal area (situated slightly anterior to the mid-line of valve). P. orbigniana (Rouillier, 1847) from the Upper Cretaceous of England (Woods, 1909, p. 256, pl. 43, figs. 1,2) resembles the Sergipe specimens in its less developed beaks and in being elongate-ovate but differs in having fine, irregular, tuberculate radial ribs, in addition to finer commarginal ribs, and a slightly gaping posterior end. P. molli Coquand, 1862, from the Turonian of Algeria (Coquand, 1862, p. 189, pl. 6, figs. 6,7$)$ differs in being more inflated $(\mathrm{W} / \mathrm{L}=0.67$ as opposed to 0.47 on average for the Sergipe specimens) and in having terminal beaks.

Occurrence. Albian of Texas, USA (Adkins, 1928); AlbianConiacian of Nigeria (Barber, 1958; Akpan \& Ntekim, 2004); Cenomanian-Turonian of Sergipe, Brazil (this study); Turonian of Portugal (Choffat, 1902).

Superfamily POROMYOIDEA Dall, 1886 Family POROMYIDAE Dall, 1886

Liopistha Meek, 1864
Type species. Cardium elegantulum Roemer, 1852, by original designation (non C. elegantulum Beck, $1842=$ Liopistha elegantulata Vokes, 1956).

\section{Subgenus Liopistha Meek, 1864}

Remarks. The subgenus Liopistha refers to species ornamented with fine and numerous radial ribs except on the smooth dorsal part of the posterior area. Near the umbonal area, equally developed radial and commarginal ribs intersect. Towards the ventral margin only radial ribs remain.

Liopistha (Liopistha) aequivalvis (Goldfuss, 1841) (Figures 11F-I)

1841 Corbula aequivalvis: Goldfuss, p. 250, pl. 151, figs. 15 a-b.

1841 Pholadomya caudata N.: Roemer, p. 76, pl. 10, fig. 8. ?1846 Cardium lucerna: Forbes, p. 145, pl. 17, fig. 10.

1870 Pholadomya caudata Roemer: Stoliczka, p. 79, pl. 2, figs. 10-11; pl. 16, fig. 19.

1884 Pholadomya aequivalvis Goldfuss: Holzapfel, p. 471, pl. 7, figs. 5a-b.

1889 Liopistha aequivalvis Goldfuss: Holzapfel, p. 150, pl. 9, figs. 4-5.

?1909 Liopistha, sp.: Woods, p. 258, pl. 43, figs. 5a-c.

1934 Liopistha aequivalvis (Goldfuss): Andert, p. 335, pl. 15, fig. 9; text-fig. 88.

1974 Liopistha aequivalvis (Goldfuss): Oekentorp \& Siegfried, p. 164, pl. 18, fig. 6.

1986 Liopistha (Liopistha) aequivalvis (Goldfuss): AbdelGawad, p. 184, pl. 43, figs. 1-2.

1989 Liopistha aequivalvis (Goldfuss): Dhondt \& Jagt, p. 188, pl. 1, figs. 1-6.

?2006 Liopistha cf. aequivalvis (Goldfuss): El Qot, 92, pl. 18 , fig. 13.

Material. Eleven composite moulds (NRM-PZ Mo 167888167898) from the lower Cenomanian of localities Itaporanga 2 and 3, Cotinguiba Formation, Sergipe, Brazil.

Measurements. See Table 15.

Description. Shell small to medium-sized, oval to rounded, nearly equilateral, inflated, with slightly extended and compressed posterior end. Length and height nearly equal $(\mathrm{L} / \mathrm{H}=1.14$ on average; Table 15$)$. No posterior gape. 
Anterior and posterior margins strongly convex, joining ventral margin in rounded curves. Ventral margin widely arched. Postero-dorsal and antero-dorsal margins slightly concave, joining posterior and anterior ends in obtuse angles. Umbonal area broad and moderately convex. Beaks incurved, prominent, prosogyrate, elevated above hinge and situated near middle of valves ( $\mathrm{AL} / \mathrm{L}=0.42$ on average; Table 15$)$. Ornament consisting of 17-40 unequal radial ribs crossed by commarginal growth lines (both of equal strength), forming reticulate pattern near umbonal area (Figures 11G,I). Only radial ribs persisting towards ventral margin; ribs strong near posterior side, becoming weaker towards anterior margin (Figure 11F). Posterior flank extending for approximately one-third of the total valve length from the posterior end, smooth except for fine commarginal growth lines.

Discussion. Pholadomya caudata Roemer, 1841, is closely similar to Liopistha (Liopistha) aequivalvis in shape, size and ornament and, in agreement with Dhondt \& Jagt (1989), here considered a junior synonym. Similarly, Cardium lucerna Forbes, 1846, from the Upper Cretaceous of India (Forbes, 1846, p. 145, pl. 17, fig. 10) appears identical to L. aequivalvis in outline and ornament, though it differs in having wider interspaces between the radial ribs and welldeveloped, regular commarginal ribs. These differences are probably not significant enough to justify a separate species, so $C$. lucerna is here tentatively regarded as a junior synonym. In L. sergipensis (White, 1887) from the middle Albian of Sergipe (White, 1887, p. 106, pl. 7, fig. 17), ribs cover the entire valve and are well developed ventrally and finer dorsally. In addition, the reticulate pattern of $L$. sergipensis extends from the dorsal side to the middle part of the valve [restricted to the umbonal area in $L$. $(L$. aequivalvis, Figure $11 \mathrm{G}]$. L. sergipensis also has subterminal beaks and an elevated postero-dorsal side that is higher than the antero-dorsal margin. L. inflata Whitfield, 1885, from the Maastrichtian of Tennessee, USA (Wade, 1926, p. 76 , pl. 24, figs. 7,8) has thicker radial ribs, well-developed commarginal ribs and smooth anterior and posterior flanks, except for growth lines. L. alternata Weller, 1907 from the Upper Cretaceous of New Jersey (Weller, 1907, p. 527, pl. 58 , figs. 7-9) has a more centrally located umbonal area and more regular radial ribs. $L$. (L.) ventricosa von Koenen, 1897, from the "Senonian" of Gabon (Dartevelle \& Freneix, 1957, p. 217 , pl. 33, fig. 9) shows similarities to $L$. (L.) aequivalvis in general outline and in having a smooth posterior flank but has fewer and stronger radial ribs, wide interspaces, and less developed commarginal ribs. Liopistha sp. from the Upper Cretaceous of England (Woods, 1909, p. 258, pl. 43, fig. 5) closely resembles $L$. aequivalvis but differs from the Sergipe specimens in being much smaller $(\mathrm{L}=4 \mathrm{~mm}, \mathrm{H}=3 \mathrm{~mm}, \mathrm{~W}$ $=2.6 \mathrm{~mm}$ as opposed to $\mathrm{L}=28 \mathrm{~mm}, \mathrm{H}=26 \mathrm{~mm}, \mathrm{~W}=19.8$ $\mathrm{mm}$ on average).

Occurrence. Cenomanian of Sergipe, Brazil (this study); probably Campanian of Egypt (El Qot, 2006); CampanianMaastrichtian(?) of Germany (Roemer, 1841; Oekentorp \& Siegfried, 1974) and north-western Europe (Dhondt \& Jagt, 1989); Maastrichtian of Poland (Abdel-Gawad, 1986), "Senonian" of India (Stoliczka, 1870); recorded from Turonian(?)-Coniacian to Maastrichtian from England across to Crimea, possibly extending into Central Asia (Dhondt \& Jagt, 1989)

\section{Subgenus Psilomya White, 1874}

Type species. Liopistha (Psilomya) meekii White, 1874, by monotypy.

Remarks. The subgenus Psilomya comprises species with a compressed posterior end, less developed radial ornament, and well-developed prosogyrate beaks, situated approximately one-third of the total valve length from the anterior end.

\section{Liopistha (Psilomya) elongata Stanton, 1894}

(Figures 11J-L)

1894 Liopistha (Psilomya) elongata n. sp.: Stanton, p. 119, pl. 26, figs. 11-12.

1900 Liopistha concentrica, Stanton (including L. elongata, Stanton): Herrick \& Johnson, p. 208, pl. 41, figs. 11-12.

?1996 Psilomya elongata Stanton, 1893: Kirkland, p. 56, pl. 25, figs. G-J.

v1999 Liopistha (Psilomya) concentrica Stanton, 1893: Seeling, p. 135 (pars, cf. Appendix 1 herein).

2014 Liopistha (Psilomya) elongata Stanton, 1894: AyoubHannaa et al., p. 129, pl. 13, fig. 3.

Material. Three internal moulds (NRM-PZ Mo 167899 167901) from the upper Cenomanian-lower Turonian of

Table 15. Dimensions (mm) of Liopistha (Liopistha) aequivalvis (Goldfuss, 1841).

\begin{tabular}{|c|c|c|c|c|c|c|c|c|}
\hline Specimen & $\mathrm{L}$ & $\mathrm{H}$ & $\mathrm{W}$ & $\mathrm{AL}$ & $\mathrm{nr}$ & $\mathrm{L} / \mathrm{H}$ & $\mathrm{AL} / \mathrm{L}$ & $\mathrm{W} / \mathrm{L}$ \\
\hline NRM-PZ Mo 167888 & 39 & 33 & c. 26 & 17 & 40 & 1.18 & 0.43 & c. 0.66 \\
\hline NRM-PZ Mo 167889 & 28 & 23 & c. 21 & 14 & 34 & 1.22 & 0.50 & c. 0.75 \\
\hline NRM-PZ Mo 167890 & 25 & 32 & 20 & c. 12 & 25 & 1.28 & 0.48 & 0.80 \\
\hline NRM-PZ Mo 167891 & 36 & 32 & 28 & c. 13 & 29 & 1.12 & 0.36 & 0.78 \\
\hline NRM-PZ Mo 167892 & 15 & 15 & 10 & 5 & 17 & 1.00 & 0.33 & 0.66 \\
\hline NRM-PZ Mo 167893 & 22 & 21 & 14 & 10 & -- & 1.04 & 0.45 & 0.63 \\
\hline Range & $15-39$ & $15-33$ & $10-28$ & $5-17$ & $17-40$ & $1.00-1.28$ & $0.33-0.50$ & $0.66-0.78$ \\
\hline Mean & 28 & 26 & 19.83 & 11.83 & 29 & 1.14 & 0.42 & 0.71 \\
\hline
\end{tabular}




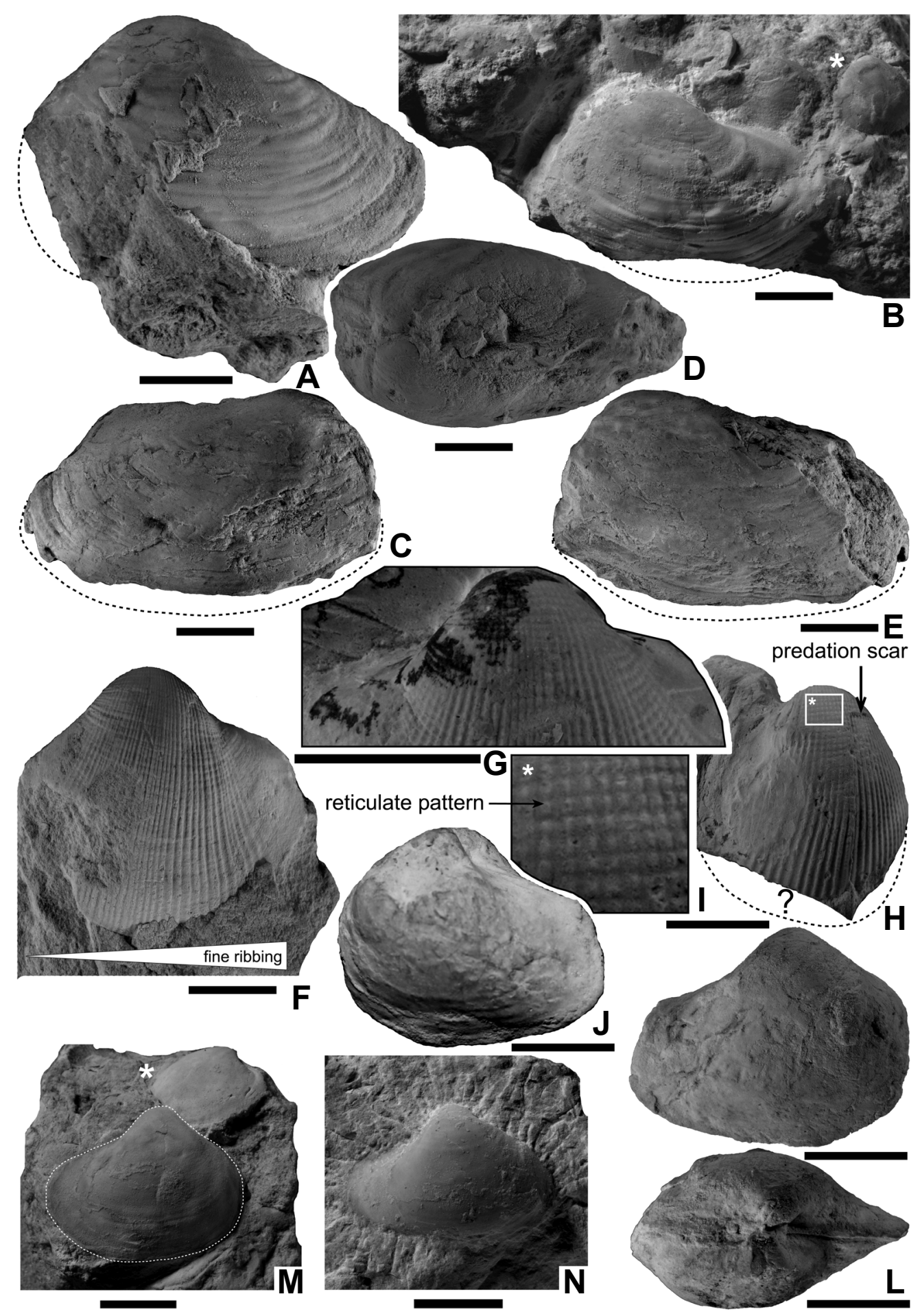

Figure 11. A-E, Pleuromya servesensis Choffat, 1901, from the upper Cenomanian-lower Turonian. A, side view of left valve of composite mould; locality Japaratuba 6 (NRM-PZ Mo 167883); B, left lateral view of composite mould; locality Japaratuba 11 (NRM-PZ Mo 167884); C, right valve of poorly preserved composite mould; D, dorsal view of articulated specimen; E, left valve; locality Machado 15 (NRM-PZ Mo 167885). F-I, Liopistha (Liopistha) aequivalvis (Goldfuss, 1841) from the lower Cenomanian of localities Itaporanga 2 and 3 . F, left lateral view of composite mould showing smooth posterior flank and decreasing strength of radial ribs towards the anterior side (arrowed) (NRM-PZ Mo 167888); G, close-up of the dorsal side showing the reticulate pattern (NRM-PZ Mo 167889); H, incomplete right lateral view of composite mould; I, close-up showing intersection of radial and commarginal ribs, forming a reticulate pattern (NRM-PZ Mo 167890). J-L. Liopistha (Psilomya) elongata Stanton, 1894, from the upper Cenomanian-lower Turonian of locality Japaratuba 16 (NRM-PZ Mo 167899). J, left lateral view of composite mould; $\mathbf{K}$, side view of right valve; L, dorsal view of articulated valves showing the abrupt decrease in inflation towards the posterior end. M-N, Liopistha (Psilomya) concentrica Stanton, 1894, from the upper Cenomanian-lower Turonian. M, side view of right valve of composite mould; locality Japaratuba 6 (NRM-PZ Mo 167902); N, side view of right valve; locality Sergipe 5 (NRM-PZ Mo 167903). All specimens from the Cotinguiba Formation of the Sergipe Basin, Brazil. White asterisks in figures B and M denote non-pholadomyid specimens [Paraesa faba (J. de C. Sowerby, 1827)]. Scale bars $=10 \mathrm{~mm}$. 
localities Japaratuba 11 and 16, Cotinguiba Formation, Sergipe, Brazil.

Measurements. See Table 16.

Description. Shell medium-sized, elongate-ovate, inequilateral, slightly inequivalved, strongly compressed posteriorly (Figure $11 \mathrm{~L})$, moderately inflated $(\mathrm{W} / \mathrm{L}=0.54$ on average; Table 16) with maximum inflation slightly below umbonal area. Posterior end elongate $(\mathrm{L} / \mathrm{H}=1.30$ on average). No posterior gape. Anterior end short slightly rounded, joining ventral margin in rounded curve. Anterodorsal margin short, straight, steeply sloping towards anterior margin. Postero-dorsal margin slightly concave. Ventral margin broadly rounded. Umbonal area broad and slightly convex. Beaks prominent, elevated above hinge line, sharply pointed, prosogyrate, situated approximately one-third of the total valve length from the anterior end. Faint growth rugae visible along ventral margin, with faint axial tubercles (Figure 11J). Hinge not visible. Specific determination of specimen NRM-PZ Mo 167901 uncertain due to poor preservation.

Discussion. Liopistha (Psilomya) elongata Stanton is readily distinguished from other Liopistha species described here by its larger, elongate shell $(\mathrm{L}=30 \mathrm{~mm}$ on average; Table 16), strongly rounded anterior margin meeting the ventral margin in a rounded angle, and its narrow and slightly convex to subtruncated posterior margin. The present specimens closely resemble $L$. (P.) elongata, as described and figured by Stanton (1894) from the Turonian(?) of Utah, USA, in general outline and ornament, but differ in being slightly smaller $(\mathrm{L}=30 \mathrm{~mm}$, $\mathrm{H}=23 \mathrm{~mm}$ on average as opposed to $\mathrm{L}=37 \mathrm{~mm}, \mathrm{H}=28 \mathrm{~mm}$ for Stanton's specimens). L. (P.) concentrica Stanton, 1894, from the Cenomanian of Texas, USA (Stanton, 1894, p. 119, pl. 26, figs. 8-10) differs in being smaller and in having a subtrigonal shell and a nearly centrally placed umbonal area. $L$. (P.) meeki White, 1874 from the Upper Cretaceous of Utah, USA (White, 1874 , p. $26 ; 1877$, p. 186 , pl. 18, figs. 14a-d) has more inflated valves with well-developed radial ribs on the posterior side. Psilomya elongata, figured and described by Kirkland (1996) from the Cenomanian of northeastern Arizona, USA, resembles the present specimens in having large valves $(\mathrm{L}=40 \mathrm{~mm})$ but differs in being more elongate $(\mathrm{L} / \mathrm{H}=1.67$, as opposed to 1.30 on average for the Sergipe specimens) and in having a welldeveloped umbonal posterior ridge and a strongly rounded, broad posterior margin. Kirkland's specimens are closer to Poromya frequens (Zittel, 1864, p. 111, pl. 1, figs. 5a-f) than to $L$. (P.) elongata and are here referred with doubt to the latter species.

Occurrence. Cenomanian of New Mexico (Herrick \&
Johnson, 1900) and possibly Arizona (Kirkland, 1996); Cenomanian-Turonian of Egypt (Ayoub-Hannaa et al., 2014) and the Sergipe Basin, Brazil (this study); Turonian(?) of Utah (Stanton, 1894).

\section{Liopistha (Psilomya) concentrica Stanton, 1894} (Figures $11 \mathrm{M}, \mathrm{N}$ )

1894 Liopistha (Psilomya) concentrica n. sp.: Stanton, p. 119, pl. 26, figs. 8-10.

1900 Liopistha concentrica, Stanton (including L. elongata Stanton): Herrick \& Johnson, p. 208, pl. 33, fig. 5, pl. 41, figs. 8-10.

1953 Psilomya concentrica (Stanton): Stephenson, p. 92, pl. 22, figs. 13,20.

?1996 Psilomya sp. cf. P. concentrica Stanton: Kirkland, p. 56 , pl. 10, fig. R.

v1999 Liopistha (Psilomya) concentrica Stanton, 1893: Seeling, p. 135 (pars, cf. Appendix 1 herein), pl. 5, fig. 20.

Material. Four composite moulds (NRM-PZ Mo $167902-$ 177905) from the upper Cenomanian-lower Turonian of localities Japaratuba 6 and 11 and Laranjeiras 28 and the lower Turonian of Sergipe 5, Cotinguiba Formation, Sergipe, Brazil. Measurements. See Table 17.

Description. Shell medium-sized, subtrigonal-ovate, slightly inequilateral; posterior area slightly elongate. Moderately inflated $(\mathrm{W} / \mathrm{L}=0.42$ on average; Table 17$)$, with maximum inflation below umbonal area. Posterior end rounded, joining ventral margin in rounded angle. Anterior margin blunt, lower than posterior end, joining ventral margin in obtuse angle. Ventral margin broadly convex. Antero-dorsal and postero-dorsal margins slightly concave, steeply sloping towards anterior and posterior ends. Umbonal area trigonal, moderately convex. Beaks prominent, prosogyrate, situated more than one-third of the total valve length from the anterior end. Ornament consisting of regular growth rugae, increasing in strength ventrally.

Discussion. Liopistha (Psilomya) concentrica shows some similarities to $L$. (P.) meeki White, 1874, from the Upper Cretaceous of Utah, USA(White, 1874, p. 26; 1877, p. 186-187, pl. 18, figs. 14a-d) in general outline and size but differs in being less inflated (W/L $=0.42$ on average as opposed to 0.66$)$ and more elongate, and in having well-developed commarginal ribs and lacking radial ribbing. In addition, the postero-dorsal slope of $L$. (P.) meeki is covered by well-developed commarginal ribs,

Table 16. Dimensions (mm) of Liopistha (Psilomya) elongata Stanton, 1893.

\begin{tabular}{|c|c|c|c|c|c|c|c|}
\hline Specimen & $\mathrm{L}$ & $\mathrm{H}$ & $\mathrm{W}$ & $\mathrm{AL}$ & $\mathrm{L} / \mathrm{H}$ & $\mathrm{AL} / \mathrm{L}$ & $\mathrm{W} / \mathrm{L}$ \\
\hline NRM-PZ Mo 167899 & 28 & 22 & 16 & 7 & 1.27 & 0.25 & 0.57 \\
\hline NRM-PZ Mo 167900 & 32 & 24 & 17 & 8 & 1.33 & 0.25 & 0.53 \\
\hline NRM-PZ Mo 167901 & 30 & 23 & 16 & 8 & 1.30 & 0.27 & 0.53 \\
\hline Range & $28-32$ & $22-24$ & $16-17$ & $7-8$ & $1.27-1.33$ & $0.25-0.77$ & $0.53-0.57$ \\
\hline Mean & 30 & 23 & 16.33 & 7.66 & 1.30 & 0.26 & 0.54 \\
\hline
\end{tabular}


crossed by faint radial ribs. Poromya lata Forbes (1846, p. 141, pl. 15, fig. 14) from the Upper Cretaceous of southern India closely resembles $L$. (P.) concentrica in having a subtrigonal shell but differs in having radial rows of minute tubercles separated by wide interspaces and in being more elongate posteriorly. Psilomya cf. concentrica, figured by Kirkland (1996) from the Cenomanian of northeastern Arizona, USA, differs in having a wide umbonal area, thick commarginal ribs, and a broadly curved posterior margin.

Occurrence. Cenomanian of Texas, USA (Stanton, 1894; Stephenson, 1953) and possibly Arizona, USA (Kirkland, 1996), Cenomanian-Turonian of Sergipe, Brazil (Seeling, 1999; this study).

\section{Liopistha (Psilomya) globulosa (Forbes, 1846)}

(Figures 12A-C)

1846 Poromya globulosa, sp. nov.: Forbes, p. 141, pl. 17, fig. 6. 1871 Poromya globulosa, Forbes: Stoliczka, p. 47, pl. 3, fig. 8; pl. 16, fig. 16.

Material. Three composite moulds (NRM-PZ Mo 167906167908) from the middle-upper Cenomanian of locality Cruzes 8, the upper Cenomanian-lower Turonian of Japaratuba 11 and the lower-middle Turonian of Laranjeiras 22, Cotinguiba Formation, Sergipe Basin, Brazil.

Measurements. See Table 18.

Description. Shell medium-sized, subtrigonal-ovate, inequilateral, inflated, compressed posteriorly. Length and height nearly equal ( $\mathrm{L} / \mathrm{H}=1.15$ on average; Table 18$)$. Anterior margin slightly convex. Posterior margin rounded, joining ventral margin in rounded curve. Antero-dorsal margin truncated, elevated above hinge and forming obtuse angle with anterior margin. Postero-dorsal margin concave. No lunule. Umbonal area trigonal, moderately wide, inflated and higher than hinge line. Beaks prominent, sharply pointed and slightly incurved anteriorly (Figure 12C). Ornament consisting of commarginal ribs, crossed by faint radial striae.

Discussion. Liopistha (Psilomya) globulosa differs from other Liopistha (Psilomya) species from Sergipe in having more inflated valves $(\mathrm{W} / \mathrm{L}=0.74$ on average; Table 18$)$, a narrow and trigonal umbonal area and well-developed commarginal ribs.

According to Stanton (1894), Liopistha (Psilomya) meeki White, 1874, from the Upper Cretaceous of Utah, USA (White, 1877 , p. 186, pl. 18, figs. 14a-d) differs from $L$. (P.) globulosa in being less globose. However, the inflation of the two species is nearly the same $(\mathrm{W} / \mathrm{L}=0.74$ in globulosa and 0.66 in meeki). L. (P.) meeki also resembles $L$. (P.) globulosa in general outline and size but has more distinct radial striae (well developed posteriorly), a wide umbonal area, more elevated and strongly enrolled beaks and a wide lunule. Poromya frequens (Zittel, 1864, p. 111, pl. 1, figs. 5a-f) is larger $(\mathrm{L}=50-60 \mathrm{~mm}, \mathrm{H}=35-45 \mathrm{~mm})$, more elongate ( $\mathrm{L} / \mathrm{H}=1.38$ as opposed to 1.15 on average for the Sergipe specimens), inflated and has strongly rounded anterior and posterior margins with a broad, convex ventral margin.

It is remarkable that Liopistha (Psilomya) globulosa until now has not been described or reported from areas outside the Indian subcontinent, although Stanton (1894, p. 118), Rennie (1930, p. 191) and Dhondt (1987, p. 92) briefly discussed morphologically related species from the USA, South Africa and Austria, respectively.

Occurrence. Cenomanian-Turonian of Sergipe, Brazil (this study); Campanian-Maastrichtian of southern India (Forbes, 1846; Stoliczka, 1870).

\section{Subgenus Cymella Meek, 1864}

Type species. Pholadomya undata Meek \& Hayden, 1856, by original designation.

Remarks. Dhondt \& Jagt (1989) considered the differences between Liopistha and Cymella insufficient for generic separation. A separation at the subgeneric level is, however, justified, on the basis of differences in ornament and size. In Liopistha (Liopistha), radial ribs are well developed and sharp, extending from the umbonal area to the ventral margin and bearing sparse tubercles or spines. Commarginal ribs are subordinate and restricted to the dorsal area. By contrast,

Table 17. Dimensions (mm) of Liopistha (Psilomya) concentrica Stanton, 1893.

\begin{tabular}{lccccccc}
\hline Specimen & L & H & W & AL & L/H & AL/L & W/L \\
\hline NRM-PZ Mo 167902 & 27 & 20 & $c .11$ & 10 & 1.35 & 0.37 & $c .0 .41$ \\
NRM-PZ Mo 167903 & 23 & 17 & --- & 6 & 1.35 & 0.26 \\
NRM-PZ Mo 167904 & 21 & 17 & $c .9$ & 5 & 1.23 & 0.24 \\
NRM-PZ Mo 167905 & 22 & 16 & -- & 7 & 1.37 & 0.32 & 0.43 \\
Range & $21-27$ & $17-20$ & $9-11$ & $5-10$ & $1.23-1.37$ & $0.24-0.37$ & $0.41-0.43$ \\
Mean & 23.25 & 17.50 & 10 & 7 & 1.32 & 0.29 \\
\hline
\end{tabular}

Table 18. Dimensions (mm) Liopistha (Psilomya) globulosa (Forbes, 1846).

\begin{tabular}{lccccccc}
\hline Specimen & L & H & W & AL & L/H & AL/L & W/L \\
\hline NRM-PZ Mo 167906 & 20 & 17 & 16 & 8 & 1.18 & 0.40 \\
NRM-PZ Mo 167907 & 26 & 23 & 18 & 7 & 1.13 & 0.26 \\
Range & $20-26$ & $17-23$ & $16-18$ & $7-8$ & $1.13-1.18$ & $0.26-0.40$ & 0.69 \\
Mean & 23 & 20 & 17 & 7 & 1.15 & 0.33 & 0.74 \\
\hline
\end{tabular}


Liopistha (Cymella) is smaller and characterized by strong commarginal ribs, crossed by faint radial ribs in the middle part of the valve.

\section{Liopistha (Cymella) sp.}

(Figures 12D-H)

Material. Five composite moulds with remains of shell (NRM-PZ Mo 167909-167913) from the lower Cenomanian of localites Itaporanga 2 and 3, Cotinguiba Formation, Sergipe, Brazil.

Measurements. See Table 19.

Description. Shell small, ovate to subovate, inequilateral and moderately inflated. Length and height nearly equal (L/H $=1.03$ on average; Table 19). Maximum inflation slightly below umbonal area; shell becoming compressed posteriorly. Antero-dorsal margin short. Postero-dorsal margin higher and slightly concave. Anterior margin regularly rounded, joining regularly rounded ventral margin in rounded curve. Umbonal area trigonal and strongly convex. Beaks prominent and strongly incurved anteriorly, situated slightly anterior to mid-length of shell. Lunule broad, smooth, moderately deep. Escutcheon narrow, long and smooth. Ornament consisting of broad, regular, commarginal ribs separated by narrow interspaces. Ribs progressively thickening towards ventral margin and crossed by 18-24 weaker radial ribs (Figures 12E,F) bearing tiny spines and separated by regular interspaces. Specific determination uncertain due to poor preservation of the specimens.

Discussion. Liopistha (Cymella) undata (Meek \& Hayden, 1856) from the Upper Cretaceous of Idaho (Meek, 1876, p. 236, pl. 39, figs. 1a,b) and New Jersey, USA (Richards, 1958, p. 171, pl. 27, fig. 9) differs from the Sergipe specimens in being more elongate $(\mathrm{L} / \mathrm{H}=0.73$ in Richards's material as opposed to 1.03 on average for the Sergipe specimens) and in having a straight postero-dorsal margin, narrow and compressed posterior side and fewer commarginal ribs. $L$. (C.) bella Conrad, 1873, from the Upper Cretaceous of North Carolina, USA (Miller, 1911, p. 96, pl. 5, fig. 10) and L. (C.) bella texana Stephenson, 1941 from the Upper Cretaceous of Texas, USA (Stephenson, 1941, p. 165, pl. 26, figs. 21-23) differ in having nine thick radial ribs, concentrated in the middle part of the valve, and in being more elongate $(\mathrm{L} / \mathrm{H}=1.48$, as opposed to 1.03 on average for the Sergipe specimens).

Occurrence. Cenomanian of Sergipe, Brazil (this study).

Subgenus Sergipemya n. subgen.

Type species. Homomya alta Roemer, 1852.
Etymology. Named after the Sergipe Basin, from where the specimens described here derive.

Diagnosis. Large to very large Liopistha with highly inflated, subtrigonal to transversely oblong shell; beaks well developed, sharply pointed, strongly incurved, prosogyrate; umbonal anterior ridge well developed, extending from front of umbonal area to anterior end, forming the boundary of a deep depression; posterior gape lacking; numerous fine commarginal ribs covering the valves and crossed by faint radial tubercles; left valve with two unequal cardinal teeth, with a cardinal tear-shaped socket in-between.

Remarks. The genus Liopistha is characterized by radial ornament, which is clearly visible in the figures of the type species (Roemer, 1852, pl. 6, figs. 5a-c). The hinge structure of Roemer's holotype has not been described and remains unknown. Dhondt \& Jagt (1989, p. 189) noted that both radial and commarginal elements are equally developed near the umbonal area but towards the ventral margin, only radial ornament remains. They described also the hinge structure of both valves, using the term "tooth-like partition" for a small cardinal tooth directely attached to the hinge margin and situated above the large cardinal tooth. They pointed out that the right valve carries two large cardinal teeth and one thin tooth-like partition, whereas the left valve has one large and one small cardinal tooth and a thin tooth-like partition (Dhondt \& Jagt, 1989, pl. 1, fig. 7; pl. 2, fig. 1).

The subgenus Psilomya differs from the nominal subgenus mainly in its smaller size and and weaker radial ribs. The Sergipe specimens of Liopistha (Liopistha) show similar hinge structures, with one large and one small cardinal tooth, separated by a tear-shaped cardinal socket in the left valve. Liopistha (Sergipemya) is readily distinguished from the other subgenera by its (i) large to very large, highly inflated valves, (ii) well-developed commarginal ribs, which cover the entire valve surface and are crossed by faint radial tubercles, (iii) well-developed anterior umbonal ridge, (iv) prominent and strongly enrolled beaks, and (v) deep and wide anterior depression.

\section{Liopistha (Sergipemya) alta (Roemer, 1852)} (Figures 12I-M, 13A-D)

1852 Homomya alta n. sp.: Roemer, p. 45, pl. 6, fig. 11. 1912 Liopistha (Psilomya) alta Roemer: Pervinquière, p. 293, pl. 20, fig. 20.

?1919 Liopistha (Psilomya) alta Roemer: Greco, p. 236, pl. 5 (21), fig. 15.

Table 19. Dimensions ( $\mathrm{mm}$ ) of Liopistha (Cymella) sp.

\begin{tabular}{lcccccccc}
\hline Specimen & $\mathrm{L}$ & $\mathrm{H}$ & $\mathrm{W}$ & $\mathrm{AL}$ & $\mathrm{nr}$ & $\mathrm{L} / \mathrm{H}$ & $\mathrm{AL} / \mathrm{L}$ & $\mathrm{W} / \mathrm{L}$ \\
\hline NRM-PZ Mo 167909 & 15 & 15 & 8 & 7 & 24 & 1.00 & 0.47 & 0.47 \\
NRM-PZ Mo 167910 & 13 & 13 & 7 & 4 & 20 & 1.00 & 0.31 & 0.53 \\
NRM-PZ Mo 167911 & 13 & 12 & 8 & 4 & 18 & 1.08 & 0.31 & 0.61 \\
Range & $13-15$ & $12-15$ & $7-8$ & $4-7$ & $18-24$ & $1.00-1.08$ & $0.31-0.47$ & $0.47-0.61$ \\
Mean & 13.66 & 13.33 & 7.66 & 5.00 & 20.66 & 1.03 & 0.36 & 0.54 \\
\hline
\end{tabular}




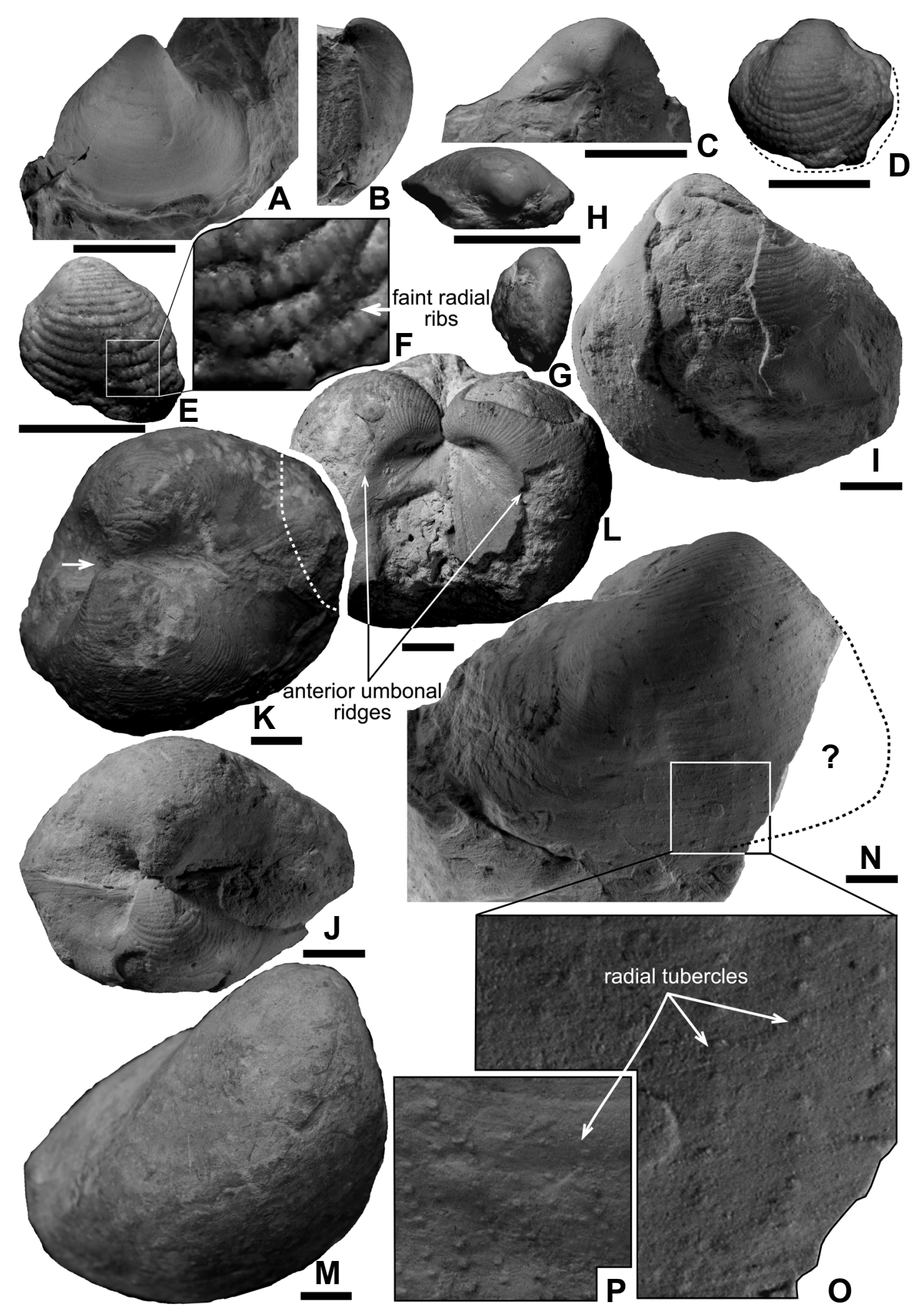

Figure 12. A-C, Liopistha (Psilomya) globulosa (Forbes, 1846) from the upper Cenomanian of locality Cruzes 8 (NRM-PZ Mo 167906). A, left lateral view; B, anterior view of left valve; C, close-up view showing the sharply pointed beak. D-H, Liopistha (Cymella) sp. from the lower Cenomanian of locality Itaporanga 2. D, side view of right valve of composite mould (NRM-PZ Mo 167909); E, left lateral view of composite mould; $\mathbf{F}$, close-up view showing thick commarginal ribs crossed by faint radial ribs in the postero-ventral and central parts; $\mathbf{G}$, anterior view; H, dorsal view showing the smooth umbonal area (NRM-PZ Mo 167910). I-M, Liopistha (Sergipemya) alta (Roemer, 1852) from the upper Cenomanian-upper Turonian. I. left lateral view with shell remains showing the ornament style; J, dorsal view of articulated valves showing lack of posterior gape; locality Japaratuba 4 (NRM-PZ Mo 167914); K, dorsal view showing deep anterior depression (arrowed); locality Cajaíba 7 (NRM-PZ Mo 167915); L, anterior view showing strong anterior umbonal keels, strong anterior inflation and enrolled beaks; locality Japaratuba 6 (NRM-PZ Mo 167916); M, side view of right valve of internal mould; locality Cajaíba 7 (NRM-PZ Mo 167922). N-P, Liopistha (Sergipemya) gigantea (J. Sowerby, 1818) from the lower-middle Turonian of locality Laranjeiras 22. N, right lateral view of incomplete composite mould; O-P, close-ups showing widely spaced radial rows of faint granules (NRM-PZ Mo 167928 and Mo 167929). All specimens from the Cotinguiba Formation of the Sergipe Basin, Brazil. Scale bars $=10 \mathrm{~mm}$. 
v1999 Liopistha (Psilomya) ligeriensis (d'Orbigny, 1845): Seeling, p. 136, pl. 6, figs. 5-7.

v1999 Liopistha (Psilomya) cf. alta (Roemer, 1852): Seeling, p. 137 (pars, cf. Appendix 1 herein), pl. 6, figs. 8-9.

Material. Fourteen composite and internal moulds, some of which with remains of shell (NRM-PZ Mo 167914-167927), from the upper Cenomanian-lower Turonian of localities Japaratuba 4, 6 and 16 and the upper Turonian of Mucuri 10 and Cajaíba 7, Cotinguiba Formation, Sergipe, Brazil.

Measurements. See Table 20.

Description. Subtrigonal to transversely oblong, equivalved, inequilateral, highly inflated $(\mathrm{W} / \mathrm{L}=0.78$ on average; Figure 13D; Table 20), with thin shell wall. Length and height nearly equal $(\mathrm{L} / \mathrm{H}=1.08$ on average; Figure $13 \mathrm{C})$. Maximum inflation below umbonal area, with valves slightly compressed posteriorly. Anterior margin truncated, joining ventral margin in rounded angle. Antero-dorsal margin slightly convex to straight, steeply sloping towards anterior margin and forming obtuse angle. Postero-dorsal margin straight to slightly concave, gradually sloping towards posterior margin. No posterior gape. Ventral margin broad and regularly convex. Umbonal area trigonal, strongly convex. Beaks prominent, sharply pointed, enrolled (Figure 12L), anteriorly incurved, elevated above dorsal margin and situated one-fourth of the total valve length from the anterior end. Hinge of left valve composed of one large and one small cardinal teeth with a tear-shaped cardinal socket in-between (Figure 13A,B). Hinge structure of right valve not preserved. Anterior umbonal ridge well developed, extending from umbonal area to anterior end, forming boundary of deep depression on anterior part (Figure 12L). Posterior umbonal ridge moderately well developed in some specimens (Figure 12M). Ornament consisting of numerous fine, well-developed commarginal ribs, regularly distributed along dorsal area and weakening towards ventral and posterior areas. Radial ornament absent.

Discussion. Liopistha (Sergipemya) alta is easily recognized by its irregular commarginal ribs, absence of radial ornament, a triangular umbonal area, truncated antero-dorsal margin, highly inflated valves $(\mathrm{W} / \mathrm{L}=0.78$ on average), well- developed posterior umbonal ridge, and prominent and strongly enrolled beaks.

Liopistha (Psilomya) pervinquierei Greco, 1919, from the Cenomanian of Egypt (Greco, 1919, p. 234, pl. 5, figs. $13,14)$ differs in being less inflated and in having few, thick commarginal ribs and rounded margins. L. (S.) alta (Roemer, 1852) from the same area (Greco, 1919, p. 236, pl. 5, fig. 15) is an internal mould without preserved ornament and less prominent beaks. Therefore, identification must be considered doubtful.

Corbula gigantea Sowerby (1818, p. 13, pl. 209, figs. 5-7) from the upper Albian of England was placed by Woods (1909) and Pervinquière (1912) in Liopistha (Psilomya). This species differs from the Sergipe specimens in being larger $(\mathrm{L}=100 \mathrm{~mm}, \mathrm{H}=80 \mathrm{~mm})$ and more elongate $(\mathrm{L} / \mathrm{H}=1.32$ as opposed to 1.08) and in having fewer radial tubercles along the ventral margin.

Occurrence. Cenomanian of Texas, USA (Roemer, 1852), Egypt (Greco, 1919) and Tunisia (Pervinquière, 1912); Cenomanian-Turonian of Sergipe, Brazil (Seeling, 1999; this study).

Liopistha (Sergipemya) gigantea (J. Sowerby, 1818) (Figures 12N-P, 14A-C)

1818 Corbula gigantea Sowerby, p. 13, pl. 209, figs. 5-7. 1909 Liopistha (Psilomya) gigantea (Sowerby): Woods, p. 257, pl. 43, figs. 3-4; pl. 44, figs. 1-2.

1912 Liopistha (Psilomya) gigantea J. Sowerby: Pervinquière, p. 292, pl. 20, fig. 21.

v2004 Psilomya sp.: Seeling, fig. 3a.

2014 Liopistha? gigantea (Sowerby 1818): Ayoub-Hannaa et al., p. 130, pl. 13, figs. 4-6.

Material. Nine internal and composite moulds (NRM-PZ Mo 167928-167936) from the lower-middle Turonian of localities Laranjeiras 21 and 22, Pedra Furada 4 and São Roque 5 and from the upper Turonian of Cajaíba 7, Cotinguiba Formation, Sergipe, Brazil.

Measurements. See Table 21.

Table 20. Dimensions (mm) of Liopistha (Sergipemya) alta (Roemer, 1852).

\begin{tabular}{|c|c|c|c|c|c|c|c|}
\hline Specimen & $\mathrm{L}$ & $\mathrm{H}$ & $\mathrm{W}$ & $\mathrm{AL}$ & $\mathrm{L} / \mathrm{H}$ & $\mathrm{AL} / \mathrm{L}$ & $\mathrm{W} / \mathrm{L}$ \\
\hline NRM-PZ Mo 167914 & 60 & 54 & 45 & 20 & 1.18 & 0.33 & 0.75 \\
\hline NRM-PZ Mo 167915 & 72 & 66 & 58 & 20 & 1.09 & 0.28 & 0.80 \\
\hline NRM-PZ Mo 167916 & 64 & 65 & 53 & 28 & 0.98 & 0.43 & 0.83 \\
\hline NRM-PZ Mo 167917 & 73 & 65 & 60 & 20 & 1.12 & 0.27 & 0.82 \\
\hline NRM-PZ Mo 167918 & 85 & 77 & 67 & 23 & 1.10 & 0.37 & 0.79 \\
\hline NRM-PZ Mo 167919 & 78 & 70 & 55 & 28 & 1.11 & 0.35 & 0.71 \\
\hline NRM-PZ Mo 167920 & 76 & 78 & 65 & 22 & 0.97 & 0.29 & 0.86 \\
\hline NRM-PZ Mo 167921 & 70 & 66 & 50 & 18 & 1.06 & 0.26 & 0.71 \\
\hline NRM-PZ Mo 167922 & 68 & 60 & 48 & 25 & 1.13 & 0.38 & 0.70 \\
\hline NRM-PZ Mo 167923 & 74 & 70 & 63 & 15 & 1.06 & 0.20 & 0.85 \\
\hline Range & $60-85$ & $54-78$ & $45-67$ & $15-28$ & $0.97-1.18$ & $0.20-0.43$ & $0.70-0.86$ \\
\hline Mean & 72 & 67.1 & 56.4 & 21.9 & 1.08 & 0.31 & 0.78 \\
\hline
\end{tabular}



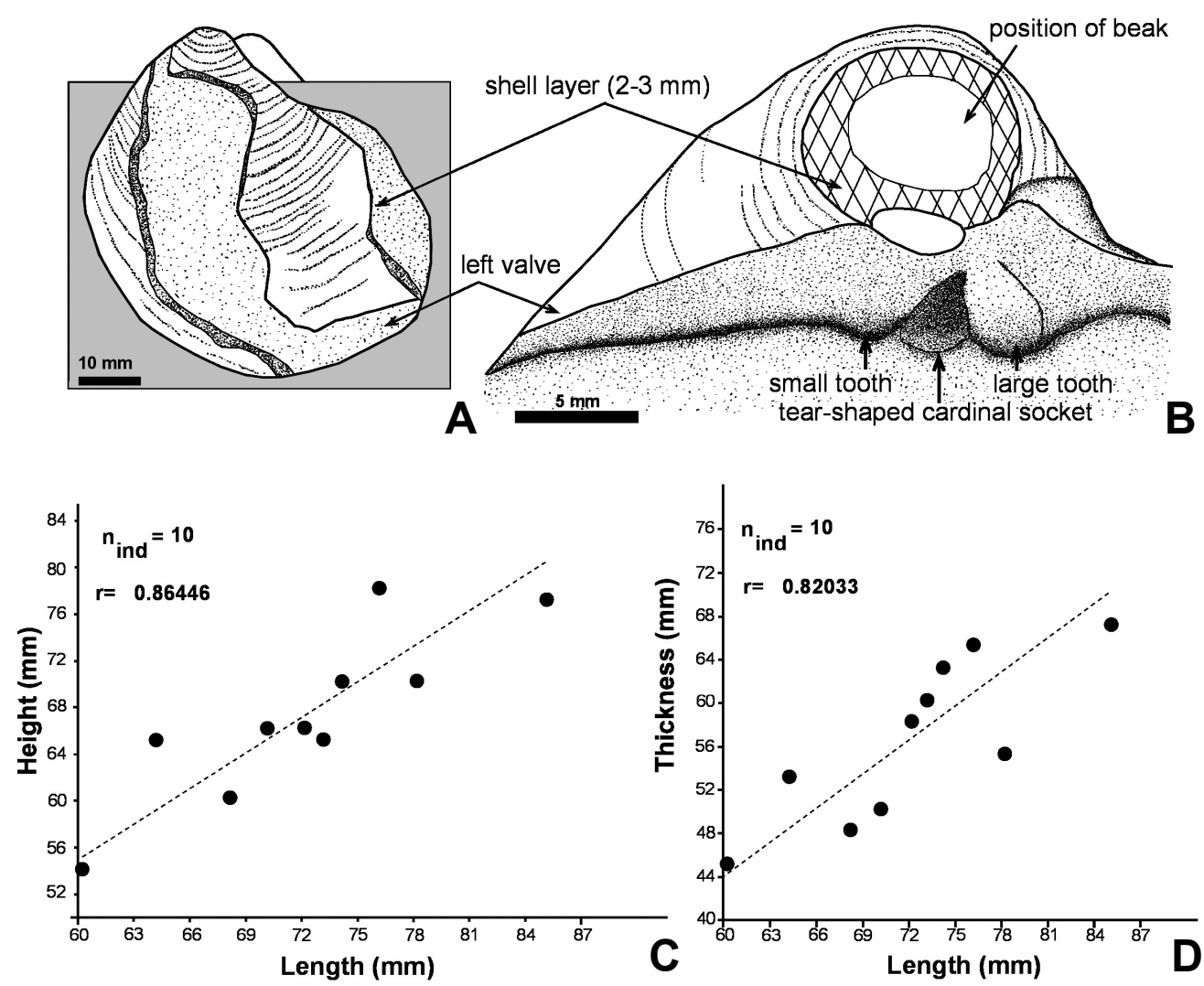

Figure 13. A-B, polished section through hinge of Liopistha (Sergipemya) alta (Roemer, 1852), showing one large and one small cardinal tooth with a tear-shaped socket in-between in left valve. C-D, length/height and length/thickness ratios of $L$. (S.) alta from the upper CenomanianTuronian of the Sergipe Basin, Brazil.

Description. Shell large, elongate-ovate to roundedquadrangular, strongly inequilateral and inflated $(\mathrm{W} / \mathrm{L}$ $=0.60$ on average; Table 21). Maximum inflation below umbonal area; valves abruptly compressed towards posterior side. Posterior margin rounded, joining ventral margin in rounded curve. No posterior gape. Anterior margin slightly convex to straight, joining the ventral margin in rounded angle. Ventral margin broadly convex. Posterodorsal margins slightly concave. Umbonal area broad, trigonal, moderately inflated. Beaks elevated, sharply pointed, prominent, strongly incurved anteriorly, situated one-third of the total valve length from the anterior end. Posterior adductor muscle scar nearly circular (Figure 14C). Ornament consisting of closely spaced, fine commarginal ribs, being most distinct dorsally and crossed by radial rows of faint granules further away from the umbonal area towards ventral margin (Figures 12O-P).

Discussion. The similar species Poromya superba Stoliczka, 1870 from the Upper Cretaceous of India (Stoliczka, 1870, p. 48, pl. 3, figs. 2-4) and Cameroon (as Liopistha superba STOL.?; Riedel, 1933, p. 68, pl. 5, fig. 1) differs from Liopistha (Sergipemya) gigantea in having well-developed, regular, commarginal ribs covering the entire valve surface, the umbonal area less incurved anteriorly, numerous radial rows of faint granules separated by narrower interspaces, strongly rounded ventral and posterior margins, and in being less elongate and more inflated.
Occurrence. Aptian of Tunisia (Pervinquière, 1912); Albian of England (Sowerby, 1818; Woods, 1909; Woods \& Jones, 1996, p. 38) and Peru (Hillebrandt, 1970); Cenomanian of the Sinai Peninsula, Egypt (Ayoub-Hannaa et al., 2014); Turonian of Sergipe, Brazil (Seeling, 2004; this study); Upper Cretaceous of South India (Stoliczka, 1870, p. 42).

$$
\text { Megaporomya Ayoub-Hannaa et al., } 2013
$$

Type species. Megaporomya reymenti Ayoub-Hannaa et al., 2013, by original designation.

\section{Megaporomya? cf. supermensa (White, 1887)}

(Figures 14D-H)

cf. 1887 Isocardia supermensa (sp. nov.): White, p. 80, pl. 6, figs. 1-2.

cf. 1937 Isocardia supermensa White: Maury, p. 70, pl. 9, figs. 16-17.

v1983 Liopistha (Psilomya) supermensa White [sic]: Bengtson, p. 47 (pars Megaporomya reymenti Ayoub-Hannaa et al., 2013).

cf. 1999 Liopistha (Psilomya) supermensa (White): Seeling, p. 138, pl. 7, figs. 1-2.

non 2011 Liopistha (Psilomya) supermensa (White, 1887): Andrade \& Santos, p. 234, figs. 2:5-7 (= Megaporomya reymenti Ayoub-Hannaa et al., 2013). 
Table 21. Dimensions (mm) of Liopistha (Sergipemya) gigantea (Sowerby, 1818).

\begin{tabular}{lccccccc}
\hline Specimen & L & H & W & AL & L/H & AL/L & W/L \\
\hline NRM-PZ Mo 167927 & 71 & 52 & -- & 20 & 1.36 & 0.28 & -- \\
NRM-PZ Mo 167928 & 69 & 56 & $c .45$ & 28 & 1.23 & 0.40 & c. 0.65 \\
NRM-PZ Mo 167929 & 87 & 60 & -- & 35 & 1.45 & 0.40 \\
NRM-PZ Mo 167930 & 67 & 51 & 45 & 25 & 1.31 & 0.37 & 0.67 \\
NRM-PZ Mo 167931 & 92 & 73 & 46 & 33 & 1.26 & 0.36 & 0.50 \\
NRM-PZ Mo 167932 & 78 & 60 & 45 & 27 & 1.30 & 0.35 & 0.58 \\
NRM-PZ Mo 167933 & 91 & 72 & -- & 27 & 1.26 & 0.29 & -- \\
Range & $67-92$ & $51-73$ & $45-46$ & $20-35$ & $1.23-1.45$ & $0.28-0.40$ & $0.50-0.67$ \\
Mean & 67.28 & 60.57 & 45.25 & 27.86 & 1.31 & 0.35 \\
\hline
\end{tabular}

Material. Twelve articulated composite and internal moulds (NRM-PZ Mo 167937-167948) from the upper Cenomanianlower Turonian of localities Japaratuba 4 and 11 and Jardim 31, the lower-middle Turonian of Laranjeiras 21 and the upper Turonian of Cajaíba 7 and the area of Cajaíba 7-10, Cotinguiba Formation, Sergipe, Brazil.

Measurements. See Table 22.

Description. Shell large, elongate-ovate to oblong-elongate, slightly equivalved, strongly inequilateral, highly inflated $(\mathrm{W} / \mathrm{L}=0.69$ on average; Table 22 ) and posteriorly elongate. Maximum inflation below umbonal area, with valves gradually becoming compressed posteriorly. Anterior area truncated, joining ventral margin in blunt, nearly right angle (Figure 14D). Posterior margin slightly convex, posterior end gaping. Postero-dorsal margin slightly concave and parallel to ventral margin. Ventral margin broad and slightly convex. Rounded ridge extending from front of umbonal area to middle of anterior margin, forming boundary of depression on anterior part (Figure 14F). Umbonal area wide and strongly convex. Beaks large, terminal to subterminal $(\mathrm{AL} / \mathrm{L}=0.20$ on average, Table 22), less prominent, enrolled, and slightly incurved anteriorly. Ornament consisting of commarginal ribs, well developed along dorsal area and less well developed further away from umbonal area towards ventral side.

Discussion. The specimens are characterized by terminal to subterminal beaks, a truncated anterior margin, highly inflated valves, lack of a radial ornament, and by a well-developed anterior umbonal ridge bordering a deep anterior depression.

The genus Megaporomya was erected by Ayoub-Hannaa et al. (2013) on the basis of specimens from the upper Turonianlower Coniacian? of the Sergipe Basin, Brazil. Megaporomya differs from other genera of the family Poromyidae (e.g. Poromya Forbes, 1844, and Liopistha Meek, 1864) by its large to very large size, broad and marked umbonal area, highly inflated valves, strongly enrolled beaks, and its hinge consisting of two teeth, separated by a deep socket, in each valve.

The specimens described here are similar to Megaporomya? supermensa (White, 1887) from the upper Albian of Sergipe (White, 1887, p. 80, pl. 6, figs. 1,2; Maury, 1937, p. 71, pl. 9, figs. 16,17), in having terminal beaks, a large posterior gape, and in being elongate $(\mathrm{L} / \mathrm{H}=1.46$ on average; Table 22 ) and highly inflated ( $\mathrm{W} / \mathrm{L}=0.69$ on average). However, due to the poor preservation of the present specimens and the less developed anterior umbonal ridge, a definite identification is not possible. M.? cf. supermensa differs from $M$. reymenti Ayoub-Hannaa et al., 2013, from the upper Turonian-lower Coniacian? of Sergipe (AyoubHannaa et al., 2013, p. 200, figs. 4-6,9) in being smaller $(\mathrm{L}=80.75 \mathrm{~mm}, \mathrm{H}=56.12 \mathrm{~mm}, \mathrm{~W}=57.71 \mathrm{~mm}$ as opposed to $\mathrm{L}=114.89 \mathrm{~mm}, \mathrm{H}=91.15 \mathrm{~mm}, \mathrm{~W}=84.45 \mathrm{~mm}$ on average in $M$. reymenti) and more elongate $(\mathrm{L} / \mathrm{H}=1.46 \mathrm{vs} .1 .25$ on average) and in having an antero-dorsal ridge with a deep anterior depression. In addition, the commarginal ribs of $M$. reymenti are well developed and crossed by widely spaced radial rows of minute tubercles. Further away from the umbonal area, towards the ventral margin, the radial tubercles are more strongly developed. M.? supermensa lacks radial ribs.

Occurrence. Albian-Turonian of Sergipe, Brazil (White, 1887; Maury, 1937; Seeling, 1999; this study).

\section{PALAEOBIOGEOGRAPHIC REMARKS}

A general problem when attempting to carry out palaeobiogeographic analyses of the Cretaceous marine bivalve fauna of the Sergipe Basin is the scarcity and poor preservation of many taxa, in particular the heterodonts. However, the abundance and comparatively good preservation of pholadomyid specimens have been found useful for identifying palaeobiogeographic affinities for the Cenomanian-Turonian interval.

The Sergipe pholadomyid fauna shows little endemism, with most of the taxa widely distributed in other regions such as western and southern Europe, western and northern Africa and the Middle East. Non-metric multidimensional scaling (nMDS) produces a useful ordination of regions that were geographically close to north-eastern Brazil (analysis done at the species level). For the Cenomanian, Egypt, Tunisia, Algeria and Nigeria plot close to Brazil (Figure 15A). This cluster is separated from areas along the southern margin of North America (Mexico, Arizona and Texas), India and Central Asia. The slow migration of pholadomyids across the North American Province and Indo-Pacific region (sensu Kauffman, 1973) was probably due to the large distance and depth of the ocean between these provinces. In addition, environmental conditions such as water temperature, salinity and substrate types may have been less favourable for 
Table 22. Dimensions (mm) of Megaporomya? cf. supermensa (White, 1887).

\begin{tabular}{|c|c|c|c|c|c|c|c|c|c|c|}
\hline Specimen & $\mathrm{L}$ & $\mathrm{H}$ & $\mathrm{W}$ & $\mathrm{AL}$ & $\mathrm{Hs}$ & Ws & $\mathrm{L} / \mathrm{H}$ & $\mathrm{AL} / \mathrm{L}$ & $\mathrm{Hs} / \mathrm{Ws}$ & $\mathrm{W} / \mathrm{L}$ \\
\hline NRM-PZ Mo 167937 & 81 & 58 & 56 & 29 & 37 & 13 & 1.40 & 0.36 & 2.85 & 0.69 \\
\hline NRM-PZ Mo 167938 & 88 & 63 & 56 & 23 & -- & -- & 1.40 & 0.26 & -- & 0.64 \\
\hline NRM-PZ Mo 167939 & 83 & 50 & 62 & 12 & 43 & -- & 1.66 & 0.14 & -- & 0.75 \\
\hline NRM-PZ Mo 167940 & 66 & 64 & 54 & -- & 46 & 12 & 1.03 & -- & 3.83 & 0.82 \\
\hline NRM-PZ Mo 167941 & 80 & 60 & 56 & 10 & 38 & 11 & 1.33 & 0.13 & 3.45 & 0.70 \\
\hline NRM-PZ Mo 167942 & 83 & 48 & c. 42 & 9 & 35 & -- & 1.73 & 0.11 & -- & 0.51 \\
\hline NRM-PZ Mo 167943 & 77 & 48 & 53 & 12 & -- & -- & 1.60 & 0.16 & -- & 0.69 \\
\hline NRM-PZ Mo 167944 & 88 & 58 & 67 & 20 & 40 & 16 & 1.52 & 0.23 & 2.50 & 0.76 \\
\hline Range & $66-88$ & $48-64$ & $42-67$ & $9-29$ & $35-46$ & $11-16$ & $1.03-1.73$ & $0.11-0.36$ & $2.50-3.83$ & $0.51-0.82$ \\
\hline Mean & 80.75 & 56.12 & 57.71 & 16.42 & 39.83 & 13 & 1.46 & 0.20 & 3.16 & 0.69 \\
\hline
\end{tabular}

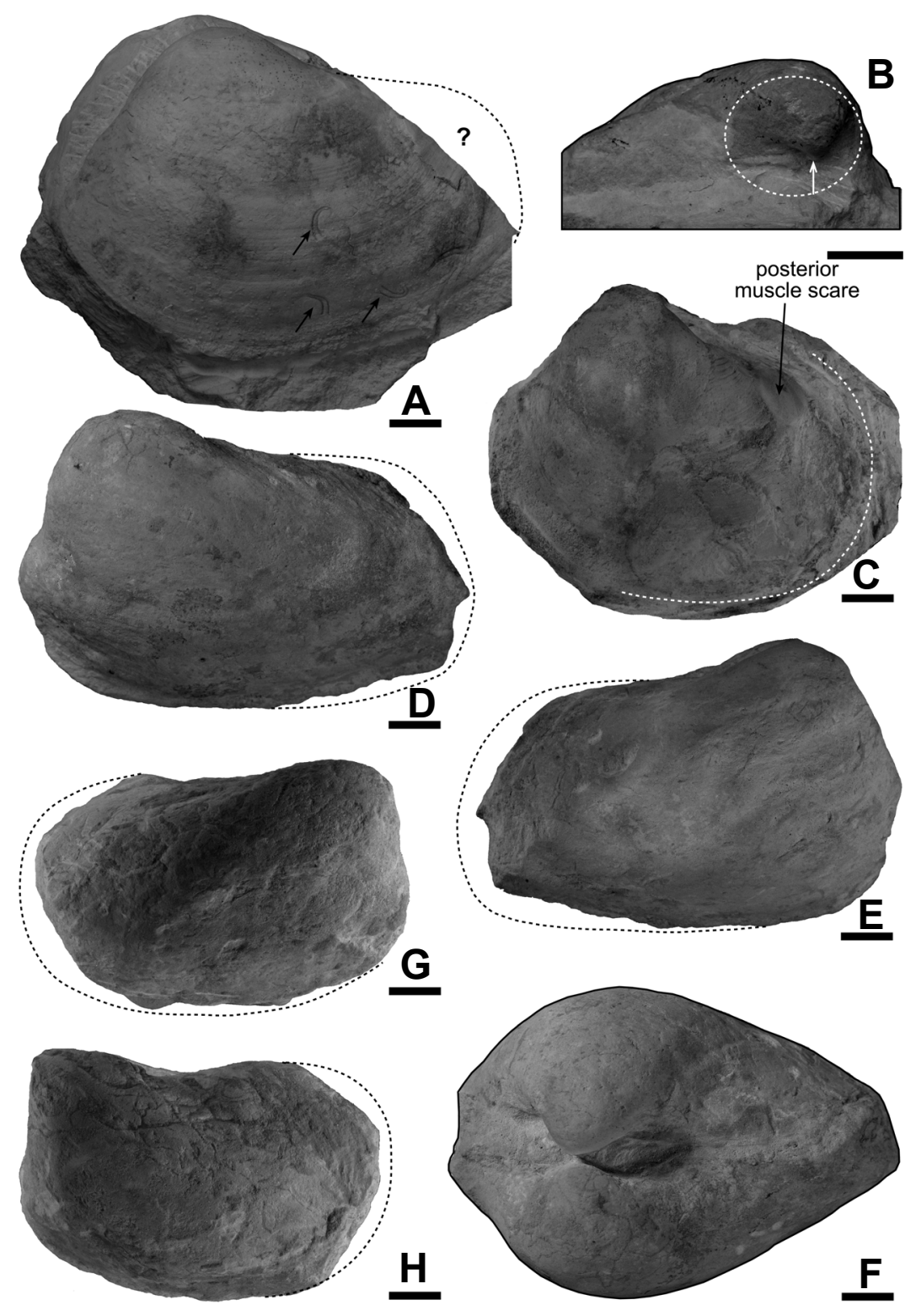

Figure 14. A-C, Liopistha (Sergipemya) gigantea (J. Sowerby, 1818) from the lower-middle Turonian. A, side view of left valve of incomplete composite mould, with serpulid encrustations (arrowed; cf. Seeling 2004, fig. 3a-b); locality Laranjeiras 22 (NRM-PZ Mo 167930); B, dorsal view of left valve of composite mould, showing strongly incurved umbonal area; locality Laranjeiras 22 (NRM-PZ Mo 167929); C, left lateral view of composite mould showing circular adductor muscle scar; locality Laranjeiras 21(NRM-PZ Mo 167932). D-H. Megaporomya? cf. supermensa (White, 1887) from the upper Cenomanian-lower Turonian of locality Japaratuba 4. D, side view of left valve of internal mould; E, Right lateral view; $\mathbf{F}$, dorsal view of articulated valves showing the deep anterior cavity and highly inflated valves (NRM-PZ Mo 167937); G, Side view of right valve of internal mould, showing terminal beaks; H, side view of left valve (NRM-PZ Mo 167938). All specimens from the Cotinguiba Formation of the Sergipe Basin, Brazil. Scale bars $=10 \mathrm{~mm}$. 
settling. According to Lazo (2007), the larvae were able to test the bottom substrate and postpone metamorphosis until they found a suitable substrate for adult life. As a result of the late Cenomanian-early Turonian maximum flooding, pholadomyid faunas were able to colonize increasingly the Western and Eastern Mediterranean subprovinces. A distinct clustering of points around Brazil (Figure 15B) supports the conclusion that the South Atlantic Subprovince was connected with the Western and Eastern Mediterranean Subprovinces (sensu Kauffman, 1973). For instance, the pholadomyids of the Gabon Basin [Pholadomya (Ph.) adversa, Ph. (Ph.) pedernalis and $P h$. (Procardia) vignesi] show strong similarities with coeval faunas of the northwestern margins of the South Atlantic. In addition, Ph. (Ph.) nodulifera and Pleuromya ligeriensis of France, Germany, Egypt, Tunisia and Algeria indicate similarities between the northern and southern Tethys. However, Angola and Cameroon plot as far away from Brazil as Central Asia (Figure 15B) and thus cannot be included in the latter provinces, although this pattern may be due to insufficient data from these West African regions. Kauffman (1973) discussed the palaeobiogeography of Cretaceous bivalves and concluded that the Sergipe Basin belongs to the South Atlantic Subprovince of the South Temperate Realm. However, because of the close affinity with the faunas of the southern Tethyan region, Westermann (2000) assigned the northern South Atlantic region to the Mediterranean-Caucasian Subrealm.

The distribution of pholadomyid taxa was probably influenced by east-west-directed currents and migration along a permanent north-south connection in the equatorial Atlantic from the Albian onwards (Figure 15C). During the late Cenomanian-early Turonian, connections with North African faunas were enhanced through the intermittent TransSaharan Seaway (e.g. Seeling \& Bengtson 2002; Courville,
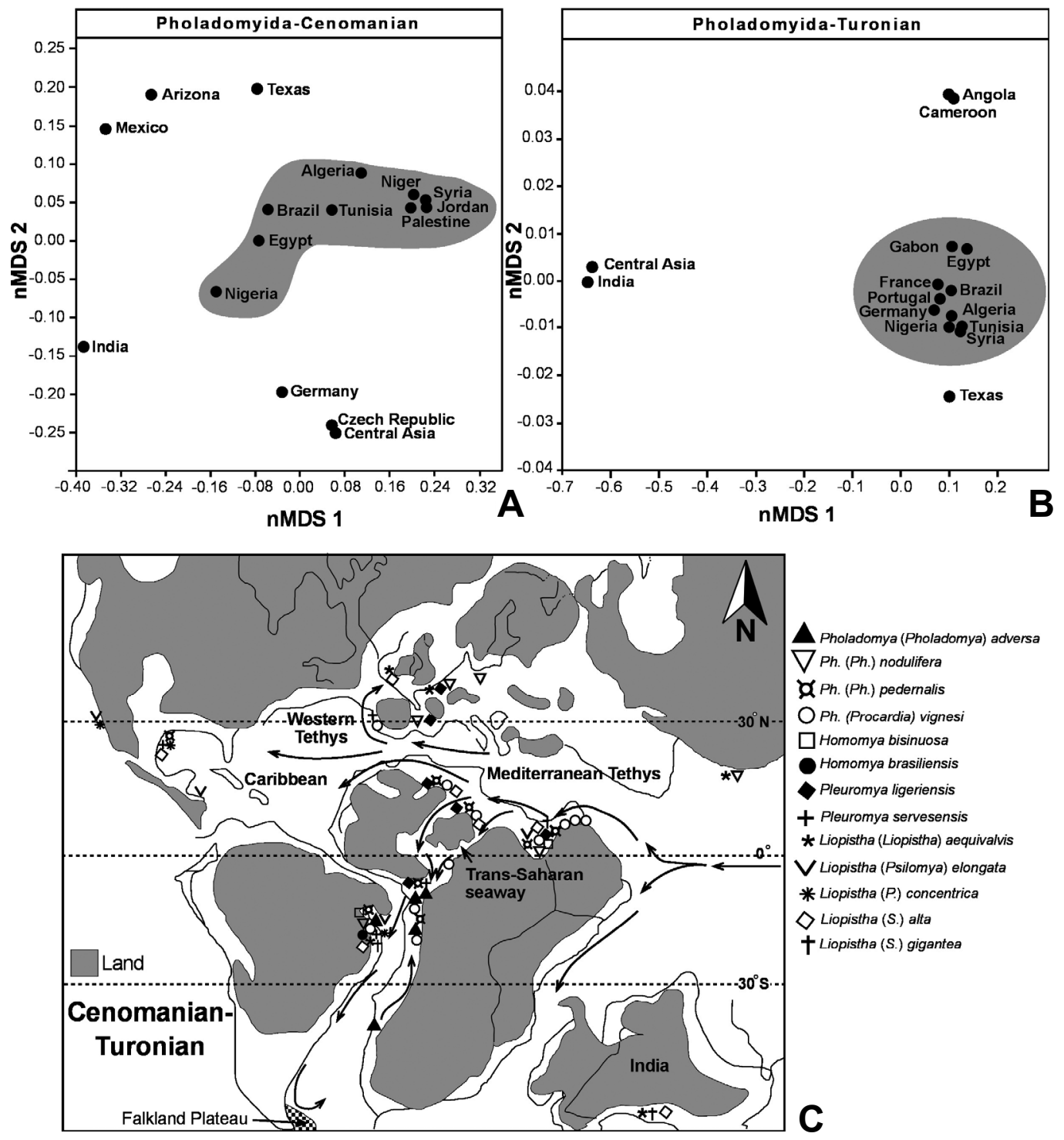

Figure 15. Non-metric multidimensional scaling (nMDS) of proportional distances of occurrences of pholadomyid taxa by country during the Cenomanian (A) and Turonian (B). C, geographic distribution and reconstruction of surface-water currents during the Cenomanian-Coniacian, based on the distribution patterns of selected pholadomyid species. Palaeogeographic base map after Seeling \& Bengtson (1999). 


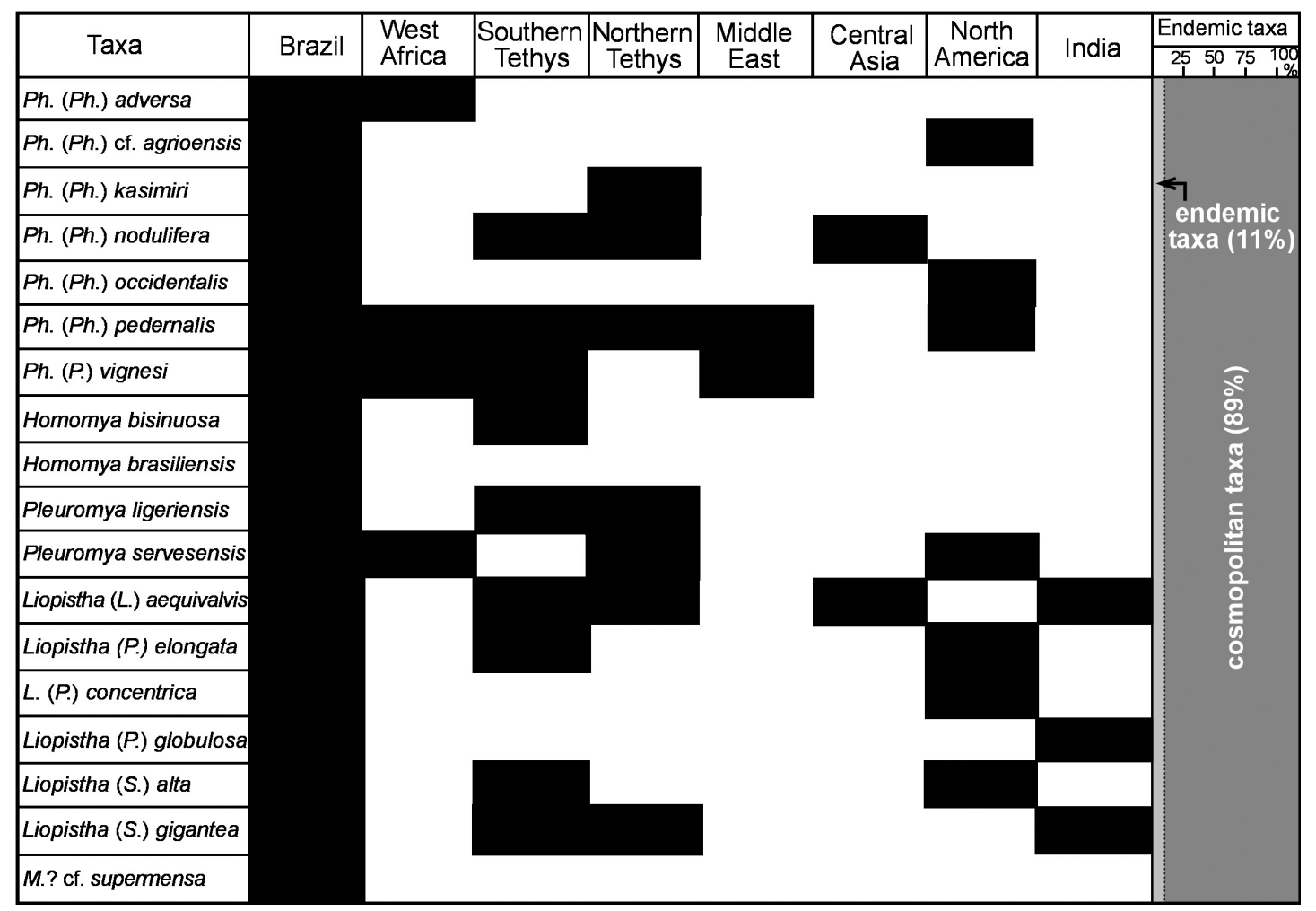

Figure 16. Geographic distribution and degree of endemism of Cenomanian-Turonian pholadomyid taxa of the Sergipe Basin, Brazil.

2007; Meister \& Piuz, 2013; Ayoub-Hannaa et al., 2014). The westward migration along the margins of the Tethys split into a northern route along southern Europe and northern Africa and a southern route along the eastern margins of Africa (e.g. Somalia, India, and Madagascar). However, there is no conclusive evidence for migration around the tip of southern Africa, as postulated by Néraudeau \& Mathey (2000).

In conclusion, the overwhelming majority (c. 90\%) of the Cenomanian-Turonian pholadomyid species of the Sergipe Basin in north-eastern Brazil show a cosmopolitan distribution, with closest ties with West Africa and the Mediterranean Province (Figure 16). The wide distribution of this group of bivalves indicates that their larvae were longlived and possessed a high dispersal potential.

\section{CONCLUSIONS}

Twenty-two species of Pholadomyida belonging to six genera and seven subgenera of the families Pholadomyidae, Pleuromyidae, and Poromyidae are described from the Cotinguiba Formation of the Sergipe Basin, north-eastern Brazil, from beds dated with ammonites as Cenomanian-early Coniacian.

Eleven species, Pholadomya (Pholadomya) cf. agrioensis Weaver, 1931, Ph. (Ph.) kasimiri Pusch, 1837, Ph. (Ph.) nodulifera Münster, 1841, Ph. (Ph.) occidentalis Morton, 1833, Ph. (Procardia) vignesi Lartet, 1877, Pleuromya ligeriensis (d'Orbigny, 1845), Pl. servesensis Choffat, 1902, Liopistha (Liopistha) aequivalvis (Goldfuss, 1841), L. (Sergipemya) gigantea (J. Sowerby, 1818), L. (Psilomya) elongata Stanton, 1894, and L. (P.) globulosa (Forbes, 1846) are recorded from the Sergipe Basin for the first time.

The new subgenus Sergipemya of the genus Liopistha is erected. It is distinguished from other subgenera of Liopistha by its numerous commarginal ribs, lack of radial ribs, large and highly inflated valves and incurved umbonal area, a well-developed rounded ridge, deep anterior cavity and the presence of two unequal cardinal teeth with a cardinal socket in the left valve.

Most of the taxa show a cosmopolitan distribution as a result of the longevity of their larvae and the widespread marine connections in Cenomanian-Turonian times.

\section{ACKNOWLEDGMENTS}

We greatly appreciate the reviews and suggestions of D.G. Lazo (Departamento de Ciencias Geológicas, Universidad de Buenos Aires) and L.R.L. Simone (Museu de Zoologia, Universidade de São Paulo). Great thanks are due to L. Egger and B. Leipner-Mata (Institut für Paläontologie, Universität Erlangen-Nürnberg, Germany) for the photographic work and for preparing the polished slabs and silicone moulds, respectively. P.B. thanks S.I. Bengtson (Heidelberg), D.A. Campos (DNPM, Rio de Janeiro) and Petrobras S.A. (Aracaju and Rio de Janeiro) for field and logistic assistance. The fieldwork was financed mainly by the Swedish Natural Science Research Council (NFR, now Vetenskapsrådet, VR). E.J.A. is grateful for the support of the German Academic Exchange Service (DAAD) and to M.J. Andrade (Aracaju, Brazil) for assistance in the field. 


\section{REFERENCES}

Abbass, H.L. 1962. A monograph on the Egyptian Cretaceous pelecypods. Cairo, Geological Survey and Mineral Research Department, Monographs of the Geological Museum, 224 p. (Palaeontological Series 1).

Abdel-Gawad, G.I. 1986. Maastrichtian non-cephalopod mollusks (Scaphopoda, Gastropoda, and Bivalvia) of the middle Vistula Valley, Central Poland. Acta Geologica Polonica, 36:1-224.

Abdel-Gawad, G.I. \& Gameil, M. 2002. Bivalves [sic] taxonomy of the Cenomanian-Turonian strata of Gabal Nezzazat, west central Sinai, Egypt. Journal of the Faculty of Science, United Arab Emirates University, 12:70-107.

Abdel-Gawad, G.I.; Orabi, O.H. \& Ayoub-Hannaa, W.S. 2004. Macrofauna and biostratigraphy of the Cretaceous section of Gebel El-Fallig area, northwest Sinai, Egypt. Egyptian Journal of Paleontology, 4:305-333.

Adkins, W.S. 1928. Handbook of Texas Cretaceous Fossils. University of Texas Bulletin, 2838:1-385.

Akpan, E.B. \& Ntekim, E.E. 2004. Cretaceous bivalves and palaeoenvironments of the Calabar Flank, SE Nigeria. Global Journal of Geological Sciences, 2:15-36. doi: 10.4314/gjgs. $v 2 i 1.18678$

Anderson, F.M. 1938. Lower Cretaceous deposits in California and Oregon. Geological Society of America Special Papers, 16:1-339. doi: 10.1130/SPE16-p1

Andert, H. 1934. Die Kreideablagerungen zwischen Elbe und Jeschken: Teil III. Die Fauna der obersten Kreide in Sachsen, Böhmen und Schlesien. Abhandlungen der Preußischen Geologischen Landesanstalt, 159:5-447.

Andrade, E.J. 2005. Turonian inoceramids and biostratigraphy of the Sergipe Basin, northeastern Brazil: an integrated study of the Votorantim and Nassau quarries. Heidelberg University, Ph.D. thesis, $155 \mathrm{p}$.

Andrade, E.J.; Martins, M.R.S. \& Pereira, R.E.T.S. 2011. Novas ocorrências de Pholadomya (Mollusca - Bivalvia) no Cretáceo Superior de Sergipe. In: SIMPÓSIO DE GEOLOGIA DO NORDESTE, 24, 2011. Anais, Aracaju, SBG, p. 256.

Andrade, E.J. \& Santos, M.T. 2011. Moluscos biválvios do Turoniano (Cretáceo Superior) da bacia de Sergipe. In: I.S. Carvalho; N.K. Srivastava; O. Strohschoen Jr. \& C.C. Lana (eds.) Paleontologia: Cenários de Vida, Interciência, vol. 4, p. 229-238.

Andrade, E.J.; Seeling, J.; Bengtson, P. \& Lima, W.S. 2004. The bivalve Neithea from the Cretaceous of Brazil. Journal of South American Earth Sciences, 17:25-38. doi: 10.1016/j. jsames.2004.05.006

Ayoub-Hannaa, W.S.; Bengtson, P.; Fürsich, F.T \& Andrade, E.J. 2013. Megaporomya reymenti gen. et sp. nov. (Bivalvia, Pholadomyida) from the upper Turonian (Upper Cretaceous) of the Sergipe Basin, north-eastern Brazil. Revista Brasileira de Paleontologia, 16:197-212. doi: 10.4072/rbp.2013.2.03

Ayoub-Hannaa, W.; Fürsich, F.T \& El Qot, G.M. 2014. CenomanianTuronian bivalves from eastern Sinai, Egypt. Palaeontographica, Abteilung A, 301:63-167.

Barber, W. 1958. Upper Cretaceous Mollusca from north-eastern Nigeria. Records of the Geological Survey of Nigeria, 1956:14-46.

Benaim, N.P. \& Senra, M.C.E. 2008. O gênero Pholadomya Sowerby, 1823 (Mollusca. Bivalvia) na Formação Jandaíra (Cretáceo Superior), Bacia Potiguar: implicações paleoecológicas e paleogeográficas. Anuário do Instituto de Geociências - UFRJ, 31:88-97.
Bengtson, P. 1983. The Cenomanian-Coniacian of the Sergipe Basin, Brazil. Fossils and Strata, 12:1-78.

Bengtson, S.I.; Bengtson, P. \& Andrade, E.J. 2005. A revised ammonite biostratigraphy for the upper Turonian-lower Coniacian of the Sergipe Basin, Brazil. In: CONGRESSO BRASILEIRO DE PALEONTOLOGIA, 19, 2005. Resumo, Aracaju, SBP, UFS, CD-ROM.

Benyoucef, M.; Meister, C., Bensalah, M. \& Malti, F.Z. 2012. La plateforme préafricaine (Cénomanien supérieur-Turonien inférieur) dans la région de Béchar (Algérie). stratigraphie, paléoenvironnements. Revue de Paléobiologie, 31:205-218.

Bieler, R.; Carter, J.G. \& Coan, E.V. 2010. Classification of bivalve families. Malacologia, 52:113-133. doi: 10.4002/040.052.0201

Blanckenhorn, M. 1934. Die Bivalven der Kreideformation von Syrien-Palästina nebst einem ergänzenden Anhang über Brachiopoden, Gastropoden und Pteropoden und einem Überblick über die gesamte Molluskenfauna. Palaeontographica, Abteilung A, 81:161-296.

Busson, G.; Dhondt, A.; Amédro, F.; Néraudeau, D. \& Cornée, A. 1999. La grande transgression du Cénomanien supérieurTuronien inférieur sur la Hamada de Tinrhert (Sahara algérien): datations biostratigraphiques, environnement de dépôt et comparaison d'un témoin épicratonique avec les séries contemporaines à matière organique du Maghreb. Cretaceous Research, 20:29-46. doi: 10.1006/cres.1998.0137

Campos Neto, O.P.A.; Souza-Lima, W. \& Cruz, F.E.G. 2008. Bacia de Sergipe-Alagoas. Boletim de Geociências da Petrobras, 15:405-415.

Carter, J.G. et al. 2011. A synoptical classification of the Bivalvia (Mollusca). Paleontological Contributions, 4:1-47.

Choffat, P. 1902. Espèces nouvelles ou peu connues: quatrième série. Espèces diverses. Recueil d'études paléontologiques sur la faune crétacique du Portugal, 1:105-171.

Collignon, M. \& Roman, J. 1983. Paléontologie. In: B. Amard; M. Collignon \& J. Roman (eds.) Étude stratigraphique et paléontologique du Crétacé supérieur et Paléocène du Tinrhert-W et Tademaït-E (Sahara algérien), Lyon, Laboratoires de Géologie, p. 49-113, 129-173 (Documents 6, Hors série).

Conrad, T.A. 1852. Description of the fossils of Syria, collected in the Palestine Expedition. In: W.F. Lynch (ed.) Official Report of the United States' Expedition to Explore the Dead Sea and the River Jordan, National Observatory, p. 211-235.

Coquand, M.H. 1862. Géologie et paléontologie de la région Sud de la province de Constantine. Mémoires de la Société d'Emulation de la Provence, 2:5-342.

Courville, P. 2007. Échanges et colonisations fauniques (Ammonitina) entre Téthys et Atlantique sud au Crétacé supérieur: voies atlantiques ou sahariennes? In: L.G. Bulot; S. Ferry \& D. Grosheny (eds.) Relations entre les marges septentrionale et méridionale de la Téthys au Crétacé, Paris, École des Mines de Paris, Carnets de Géologie, p.16-19 (Mémoir 2).

Cox, L.R. 1952. Cretaceous and Eocene fossils from the Gold Coast. Bulletin of Gold Coast Geological Survey, 17:1-57.

Cox, L.R. 1969a. General features of Bivalvia. In: R.C. Moore (ed.) Treatise on Invertebrate Paleontology: Part N, Mollusca 6, Bivalvia, University of Kansas Press, p. 2-129.

Cox, L.R. 1969b. Family Pholadomyidae Gray, 1847. In: R.C. Moore (ed.) Treatise on Invertebrate Paleontology: Part N, Mollusca 6, Bivalvia, University of Kansas Press, p. 827-838.

Dartevelle, E. \& Freneix, S. 1957. Mollusques fossiles du Crétacé de la Côte occidentale d'Afrique du Cameroun à l'Angola: II. Lamellibranches. Annales du Musée royal du Congo Belge, Sciences géologiques, 20:1-271. 
Dhondt, A.V. 1987. Bivalves from the Hochmoos Formation (GosauGroup, Oberösterreich, Austria). Annalen des Naturhistorischen Museums Wien, Serie A, 88:41-101.

Dhondt, A.V. \& Dieni, I. 1988. Early Cretaceous bivalves of eastern Sardinia. Memorie di Scienze Geologiche, 40:1-97.

Dhondt, A. \& Jagt, J.W.M. 1989. Upper Cretaceous Liopistha species in north western Europe. Bulletin de l'Institut Royal des Sciences Naturelles de Belgique, Sciences de la Terre, 58:187-197.

El Qot, G.M. 2006. Late Cretaceous macrofossils from Sinai, Egypt. Beringeria, 36:3-163.

Feijó, F.J. 1995. Bacias de Sergipe e Alagoas. Boletim de Geociências da Petrobras, 8:149-161.

Fitton, W.H. 1837. Plates XI to XXIII. In: Plates and Maps in Illustration of Volume IV, Second Series, of the Transactions of the Geological Society of London, London, Geological Society, 3 p., 13 pls.

Forbes, E. 1846. Report on the fossil Invertebrata from southern India, collected by Mr. Kaye and Mr. Cunliffe. Transactions of the Geological Society of London, Second series, 7:97-174.

Fourtau, R. 1917. Catalogue des Invertébrés fossiles de l'Egypte représentés dans les collections du Musée de Géologie au Caire: Terrains crétacés, 2me Partie. Mollusques Lamellibranches. Cairo, Geological Survey of Egypt, 108 p. (Palaeontological Series 3).

Frič, A. 1883: Studien im Gebiete der böhmischen Kreideformation: Palaeontologische Untersuchungen der einzelnen Schichten: 3. Die Iserschichten. Archiv für die Naturwissenschaftliche Landesdurchforschung von Böhmen, 5:1-138.

Frič, A. 1897: Studien im Gebiete der böhmischen Kreideformation: Palaeontologische Untersuchungen der einzelnen Schichten: 6. Die Chlomeker Schichten. Archiv für die Naturwissenschaftliche Landesdurchforschung von Böhmen, 10:3-83.

Gale, A.S.; Bengtson, P. \& Kennedy, W.J. 2005. Ammonites at the Cenomanian-Turonian boundary in the Sergipe Basin, Brazil. Bulletin of the Geological Society of Denmark, 52:167-191.

Gardner, J.A. 1916. Mollusca. In: R.S. Bassler; E.W. Berry; W.B. Clark; J.A. Gardner; H.A. Pilsbry \& L.W. Stephenson (eds.) Systematic paleontology of the Upper Cretaceous deposits of Maryland. Maryland, Maryland Geological Survey, p. 371-733 (Reports 6).

Goldfuss, A. 1841. Petrefacta Germaniae tam ea, quae in museo Universitatis Regiae Borussicae Fridericiae Wilhelmiae Rhenanae servantur quam alia quaecunque in museis Hoeninghusiano [sic] Muensteriano aliisque extant, inconibus et descriptionibus illustrata. Abbildungen und Beschreibungen der Petrefacten Deutschlands und der angränzenden Länder, unter Mitwirkung des Herrn Grafen Georg zu Münster: Zweiter Theil. Divisio quarta: Molluscorum acephalicorum reliquiae. Muscheltiere der Vorwelt [7. Lieferung] Düsseldorf, Arnz \& Co., p. 225-312.

Gray, J.E. 1847. A list of the genera of Recent Mollusca, their synonyms and types. Proceedings of the Zoological Society of London, 15:129-219.

Greco, B. 1919. Fauna cretacea dell' Egitto raccolta dal Figari Bey: Parte terza. Lamellibranchiata (cont. e fine): Fasc. 2. Lamellibranchi del Turoniano e del Cenomaniano. Palaeontographia Italica, Memorie di Paleontologia, 24:1-58.

Groot, J.J.; Organist, D.M. \& Richards, H.R. 1954. Marine Upper Cretaceous formations of the Chesapeake and Delaware Canal. Newark, Delaware Geological Survey, 64 p. (Bulletin 3).

Hammer, Ø.; Harper, D.A.T. \& Ryan, P.D. 2001. PAST: palaeontological statistics software package for education and data analysis. Palaeontologia Electronica, 4. Avaliable at http// palaeo-electronica.org/2001_1/past/issue1_01.htm; accessed on $22 / 04 / 2015$.

Herrick, C.L. \& Johnson, D.W. 1900. The geology of the Albuquerque sheet. Bulletin of the Hadley Laboratory of the University of New Mexico, 2:1-67. Also in: Bulletin of the Scientific Laboratories of Denison University, 11:175-239.

Herrmannsen, A.N. 1847. Indicis generum malacozoorum primordia, vol. 1, fasc. 5. Kassel, Theodor Fischer, p. 489-616.

Hessel, M.H.R. 1985. Alguns inoceramídeos (Bivalvia) radialmente ondulados do Turoniano inferior de Sergipe. In: D.A. Campos \& R.C.G. Armesto (eds.) Coletânea de trabalhos paleontológicos, Rio de Janeiro, Departamento Nacional da Produção Mineral, Seção de Paleontologia e Estratigrafia, p. 227-237 (Boletim 27).

Hessel, M.H.R. 1988. Lower Turonian inoceramids from Sergipe, Brazil: systematics, stratigraphy and palaeoecology. Fossils and Strata, 22:1-49.

Hillebrandt, A. 1970. Die Kreide in der Zentralkordillere östlich von Lima (Peru, Südamerika). Geologische Rundschau, 59:11801203. doi: $10.1007 / B F 02042288$

Holzapfel, E. 1884. Ueber einige wichtige Mollusken der Aachener Kreide. Zeitschrift der Deutschen geologischen Gesellschaft, 36:454-484.

Holzapfel, E. 1889: Die Mollusken der Aachener Kreide (Fortsetzung und Schluss). Palaeontographica, 35:139-268.

Huntley, J.W. 2011: Exploratory multivariate techniques and their utility for understanding ancient ecosystems. In: M. Laflamme; J.D. Schiffbauer \& S.Q. Dornbos (eds.) Quantifying the evolution of early life: numerical approaches to the evaluation of fossils and ancient ecosystems, Heidelberg, Springer, p. 23-48 (Topics in Geobiology 36). doi: 10.1007/978-94-007-0680-4_2

Kauffman, E.G. 1973. Cretaceous Bivalvia. In: A. Hallam (ed.) Atlas of Palaeobiogeography, Elsevier, p. 353-383.

Kauffman, E.G. \& Bengtson, P. 1985. Mid-Cretaceous inoceramids from Sergipe, Brazil: a progress report. Cretaceous Research, 6:311-315. doi: 10.1016/0195-6671(85)90053-9

Kiessling, W.; Pandey, D.K.; Schemm-Gregory, M.; Mewis, H. \& Aberhan, M. 2011. Marine benthic invertebrates from the Upper Jurassic of northern Ethiopia and their biogeographic affinities. Journal of African Earth Sciences, 59:195-214. doi: 10.1016/j. jafrearsci.2010.10.006

Kirkland, J.I. 1996. Paleontology of the Greenhorn Cyclothem (Cretaceous: late Cenomanian to middle Turonian) at Black Mesa, northeastern Arizona. New Mexico Museum of Natural History and Science, Bulletin, 9:1-131.

Koutsoukos, E.A.M. \& Bengtson, P. 1993. Towards an integrated biostratigraphy of the Aptian-Maastrichtian of the Sergipe Basin, Brazil. Documents du Laboratoire de Géologie de Lyon, 125:241-262.

Koutsoukos, E.A.M.; Destro, N.; Azambuja Filho, N.C. \& Spadini, A.R. 1993. Upper Aptian-Lower Coniacian carbonate sequences in the Sergipe Basin, northeastern Brazil. In: T. Simo; B. Scott \& J.P. Masse (eds.) Cretaceous carbonate platforms, Tulsa, American Association of Petroleum Geologists, p. 127-144 (Memoir 56).

Koutsoukos, E.A.M.; Mello, M.R. \& Azambuja Filho, N.C. 1991. Micropalaeontological and geochemical evidence of MidCretaceous dysoxic-anoxic environments in the Sergipe Basin, northeastern Brazil. In: R.V. Tyson \& T.H. Pearson (eds.) Modern and ancient continental shelf anoxia. London, Geological Society of London, p. 427-447 (Special Publications 58).

Krach, W. 1931. Niektóre małże i ślimaki kredowe z Kazimierza nad Wisłą i z okolicy [Einige Kreide-Gastropoden und 
Lamellibranchiaten von Kazimierz an der Weichsel und Umgegend]. Rocznik Polskiego Towarzystwa Geologicznego [Annales Societatis Geologorum Poloniae], 7:355-397. [In Polish, with German summary.]

Lartet, L. 1877. Exploration géologique de la Mer Morte de la Palestine et de l'Idumée. Paris, Arthus Bertrand, 326 p.

Lazo, D.G. 2007. The bivalve Pholadomya gigantea in the Early Cretaceous of Argentina: taxonomy, taphonomy, and paleogeographic implications. Acta Palaeontologica Polonica, 52:375-390.

Lexen, M. 2013. Cenomanian-Turonian (Upper Cretaceous) Gastropods from the Sergipe Basin, North-eastern Brazil. Heidelberg University, Ph.D. thesis, 167 p.

Manso, C.L.C. \& Andrade, E.J. 2008. Equinóides do Turoniano (Cretáceo Superior) de Sergipe, Brasil. Geociencias, 27:319-327.

Mantell, G. 1822. The Fossils of the South Downs, or, illustrations of the geology of Sussex. London, Lupton Relfe, $327 \mathrm{p}$.

Maury, C.J. 1925. Fosseis terciarios do Brasil com descrição de novas formas cretaceas. Rio de Janeiro, Serviço Geologico e Mineralógico do Brasil, 711 p. (Monografia 4).

Maury, C.J. 1937. O Cretaceo de Sergipe. Rio de Janeiro, Serviço Geologico e Mineralogico do Brasil, 283 p. (Monografia 11).

Meek, F.B. 1876: A report on the invertebrate Cretaceous and Tertiary fossils of the Upper Missouri country. Report of the United States Geological Survey of the Territories, 9:1-629.

Meister, C. \& Piuz, A. 2013. Late Cenomanian-Early Turonian ammonites of the southern Tethys margin from Morocco to Oman: biostratigraphy, paleobiogeography and morphology. Cretaceous Research, 44:83-103. doi: 10.1016/j.cretres.2013.03.009

Mekawy, M.S. 2007. Upper Cretaceous bivalves from Galala Plateaux, North Eastern Desert, Egypt: a systematic paleontology. Egyptian Journal of Paleontology, 7:197-243.

Mekawy, M.S. \& Abu-Zied, H. 2008. Lower Cretaceous molluscan fauna from North Sinai, Maghara area, Egypt. Egyptian Journal of Paleontology, 8:291-334.

Miller, B.L. 1911. The Geology of Prince George's County. In: Maryland Geological Survey: Prince George's County. Baltimore, The Johns Hopkins Press, p. 83-136.

Morton, S.G. 1833. Supplement to the "Synopsis of the organic remains of the ferruginous sand formation of the United States". American Journal of Science and Arts, 23:288-294.

Néraudeau, D. \& Mathey, B. 2000. Biogeography and diversity of South Atlantic Cretaceous echinoids: implications for circulation patterns. Palaeogeography, Palaeoclimatology, Palaeoecology, 156:71-88. doi: 10.1016/S0031-0182(99)00132-7

Nilsson, S. 1827. Petrificata suecana: formationis cretaceae, descripta et iconibus illustrata: Pars Prior. Vertebrata et Mollusca sistens. Lund, Berling, 39 p.

Oekentorp, K. \& Siegfried, P. 1974. Lamellibranchiata. In: M. Kaever; K. Oekentorp \& P. Siegfried (eds) Fossilien Westfalens: Teil I. Invertebraten der Kreide, Münstersche Forschungen zur Geologie und Paläontologie, p. 123-204.

Ojeda, H.A.O. 1982. Structural framework, stratigraphy and evolution of Brazilian marginal basins. The Bulletin of the American Association of Petroleum Geologists, 66:732-749.

Ojeda, H.A.O. \& Fugita, A.M. 1976. Bacia Sergipe/Alagoas: geologia regional e perspectivas petrolíferas. In: CONGRESSO BRASILEIRO DE GEOLOGIA, 28, 1974. Anais, São Paulo, SBG, p. 137-138.

Orbigny, A.d'. 1845. Paléontologie française: description zoologique et géologique de tous les animaux mollusques et rayonnés fossiles de France: Terrains crétacés: Tome troisième [livraisons 91-102]. Paris, Arthus Bertrand, p. 289-448.
Perrilliat, M.C.; Ahmad, F. \& Vega, F.J. 2006. Upper Cretaceous (Cenomanian-Turonian) bivalves from northern Jordan, Middle East. Revista Mexicana de Ciencias Geológicas, 23:96-106.

Pervinquière, L. 1912. Études de paléontologie tunisienne: II. Gastéropodes et Lamellibranches des terrains crétacés. Paris, Carte géologique de la Tunisie, $352 \mathrm{p}$.

Pickett, T.E. 1972. Guide to common Cretaceous fossils of Delaware. Newark, Delaware Geological Survey, 28 p. (Report of Investigations, 21).

Ponte, F.C.; Fonseca, J.R. \& Carozzi, A.V. 1980. Petroleum habitats in the Mesozoic-Cenozoic of the continental margin of Brazil. In: A.D. Miall (ed.) Facts and principles of world petroleum occurrence. Calgary, Canadian Society of Petroleum Geologists, p. 857-886 (Memoir 6).

Pusch, G.G. 1837. Polens Paläontologie, oder Abbildung und Beschreibung der vorzüglichsten und der noch unbeschriebenen Petrefakten aus den Gebirgsformationen in Polen, Volhynien und den Karpathen. Stuttgart, E. Schweizerbart'sche Verlagshandlung, $218 \mathrm{p}$.

Rennie, J.V.L. 1930. New Lamellibranchia and Gastropoda from the Upper Cretaceous of Pondoland (with an appendix on some species from the Cretaceous of Zululand). Annals of the South African Museum, 28:159-260.

Reyment, R.A. \& Tait, E.A. 1972. Biostratigraphical dating of the early history of the South Atlantic Ocean. Philosophical Transactions of the Royal Society of London B, 264:55-95. doi: 10.1098/rstb.1972.0009

Richards, H.G. 1958. Cretaceous Pelecypoda of New Jersey. In: H.G. Richards; C.W. Cooke; H.F. Garner; B.F. Howell; J.A. Jeletzky; A.K. Miller; H.W. Miller Jr.; R.C. Ramsdell; J.B. Reeside Jr.; H.B. Roberts \& J.W. Wells (eds.) The Cretaceous fossils of New Jersey: Part 1. Porifera, Coelenterata, Annelida, Echinoidea, Brachiopoda and Pelecypoda, Trenton, New Jersey Geological Survey, p. 59-266 (Bulletin 61).

Riedel, L. 1933. Die Oberkreide vom Mungofluß in Kamerun und ihre Fauna. Beiträge zur geologischen Erforschung der deutschen Schutzgebiete, 16:1-154.

Roemer, F.A. 1841. Die Versteinerungen des norddeutschen Kreidegebirges [2. Lieferung]. Hannover, Hahnschen Hofbuchhandlung, p. 49-145.

Roemer, F.A. 1852. Die Kreidebildungen von Texas und ihre organischen Einschlüsse. Bonn, A. Marcus, 100 p.

Runnegar, B. 1972. Anatomy of Pholadomya candida (Bivalvia) and the origin of the Pholadomyidae. Proceedings of the Malacological Society of London, 40:45-58.

Schaller, H. 1970: Revisão estratigráfica da Bacia de Sergipe/ Alagoas. Boletim Técnico da Petrobras, 12:21-86.

Seeling, J. 1999. Palaeontology and biostratigraphy of the macroinvertebrate fauna of the Cenomanian-Turonian transition of the Sergipe Basin, northeastern Brazil, with systematic descriptions of bivalves and echinoids. Heidelberg University, Ph.D. thesis, $185 \mathrm{p}$.

Seeling, J. 2004. Bioerosion of Late Cretaceous molluscs from Sergipe, Brazil. Neues Jahrbuch für Geologie und Paläontologie, Monatshefte, 2004:413-426.

Seeling, J. \& Bengtson, P. 1999. Cenomanian oysters from the Sergipe Basin, Brazil. Cretaceous Research, 20:747-765. doi: 10.1006/cres.1999.0190

Seeling, J. \& Bengtson, P. 2002. Palaeobiogeography of the upper Cenomanian-lower Turonian macroinvertebrates of the Sergipe Basin, northeastern Brazil. In: INTERNATIONAL CRETACEOUS SYMPOSIUM, 6, 2002. Proceedings, Vienna, p. 151-168. 
Seeling, J. \& Bengtson, P. 2003a. The bivalve Pinna cretacea (Schlotheim, 1813) from the Cretaceous of Brazil. Acta Palaeontologica Polonica, 48:475-480.

Seeling, J. \& Bengtson, P. 2003b. The Late Cretaceous bivalve Didymotis Gerhardt, 1897 from Sergipe, Brazil. Paläontologische Zeitschrift, 77:153-160.

Shalem, N. 1928. Fauna nuova cenomaniana delle argille verdi di Gerusalemme. Bolletino della Società Geologica Italiana, 47:69-109.

Smith, A.B. \& Bengtson, P. 1991. Cretaceous echinoids from northeastern Brazil. Fossils and Strata, 31:1-88.

Smettan, K. 1997. Bivalven, Gastropoden und Serpuliden aus den Branderfleckschichten (Cenoman) der Fahrenbergmulde (Nördliche Kalkalpen, Bayern): Taxonomie und Palökologie. Zitteliana, 21:99-158.

Sohl, N.F. \& Koch, C.F. 1984. Upper Cretaceous (Maastrichtian) larger invertebrates from the Haustator bilira Assemblage Zone in the Atlantic Coastal Plain with further data for the East Gulf. United States Geological Survey, Open-File Report, 87194:1-192.

Souza-Lima, W.; Andrade, E.J.; Bengtson, P. \& Galm, P.C. 2002. A bacia de Sergipe-Alagoas. Evolução geológica, estratigráfica e conteúdo fossil. Aracajú, Fundação Paleontológica Phoenix, p. 1-34 (Edição especial 1).

Sowerby, J.C. 1818. The Mineral Conchology of Great Britain. London, Meredith, 193 p.

Sowerby, J.C. 1836. Descriptive notes respecting the shells figured in Plates XI to XXIII. In: W.H. Fitton (ed.) Observations on some of the strata between the Chalk and the Oxford Oolite, in the south-east of England. London, Geological Society of London, p. 335-349 (Second Series 4).

Stanton, T.W. 1894. The Colorado Formation and its invertebrate fauna. Bulletin of the United States Geological Survey, 106:1-288.

Stephenson, L.W. 1941. The larger invertebrate fossils of the Navarro Group of Texas. University of Texas Publication, 4101:1-641.

Stephenson, L.W. 1953. Larger invertebrate fossils of the Woodbine Formation (Cenomanian) of Texas. Geological Survey Professional Paper, 242:1-211, 219-225.

Stephenson, L.W. 1955. Owl Creek (Upper Cretaceous) fossils from Crowleys Ridge, southeastern Missouri. Geological Survey Professional Paper, 274:97-139.

Stoliczka, F. 1870. Cretaceous fauna of southern India: vol. 3. The Pelecypoda, with a review of all known genera of this class, fossil and Recent [Parts 1-4]. Paleontologia Indica, 6:1-222.

Szente I. 2003. Bivalve biofacies of the "Hofergrabenmergel" (Hochmoos Fm., early Santonian, Lower Gosau Subgroup). In: J.T. Weidinger; H. Lobitzer \& I. Spitzbart (eds.) Beiträge zur Geologie des Salzkammerguts, Gmundner Geo-Studien, p.165-167.

Toula, F. 1889. Geologische Untersuchungen im centralen Balkan. Denkschriften der kaiserlichen Akademie der Wissenschaften, mathematisch-naturwissenschaftliche Classe, 55:1-108

Vega, F.J.; Feldmann, R.M. \& Sour-Tovar, F. 1995. Fossil crabs (Crustacea, Decapoda) from the Late Cretaceous Cárdenas Formation, east-central Mexico. Journal of Paleontology, 69:340-350.

Vokes, H.E. 1941. Contributions to the paleontology of the Lebanon Mountain, Republic of Lebanon: Part 1. A Cenomanian pelecypod fauna from Hajula. American Museum Novitates, 1145:1-13.
Wade, B. 1926. The fauna of the Ripley Formation on Coon Creek, Tennessee. Geological Survey Professional Paper, 137:1-272.

Walter, S. 2000. Palaeoenvironmental analysis of the upper Cenomanian and lower Turonian limestone beds in the Sergipe Basin, northeastern Brazil, based on microfacies analysis, micropalaeontology, and stable isotopes. Heidelberg University, Ph.D. thesis, $107 \mathrm{p}$.

Walter, S.; Herrmann, A.D. \& Bengtson, P. 2005. Stratigraphy and facies analysis of the Cenomanian-Turonian boundary succession in the Japaratuba area, Sergipe Basin, Brazil. Journal of South American Earth Sciences, 19:273-283. doi: 10.1016/j. jsames.2005.01.009

Weaver, C.E. 1931. Paleontology of the Jurassic and Cretaceous of west central Argentina. Memoirs of the University of Washington, 1:1-595.

Weller, S. 1907. A report on the Cretaceous paleontology of New Jersey. Trenton, New Jersey Geological Survey, 1107 p. (Paleontology Series 4).

Westermann, G.E. 2000. Marine faunal realms of the Mesozoic: review and revision under the new guidelines for biogeographic classification and nomenclature. Palaeogeography, Palaeoclimatology, Palaeoecology, 163:49-68. doi: 10.1016/ S0031-0182(00)00142-5

White, C.A. 1874. Preliminary Report upon Invertebrate Fossils Collected by the Expeditions of 1871, 1872, and 1873 with Descriptions of New Species. Washington, Government Printing Office, $27 \mathrm{p}$.

White, C.A. 1877. Report upon the invertebrate fossils collected in portions of Nevada, Utah, Colorado, New Mexico, and Arizona, by parties of the expeditions of 1871, 1872, 1873, and 1874. In: G.M. Wheeler \& A.A. Humphreys (eds.) Report upon Geographical and Geological Exploration and Surveys West of the One Hundredth Meridian: 4. Paleontology. Part 1. Washington, Government Printing Office, p. 3-219.

White, C.A. 1887. Contribuições á Paleontologia do Brazil. Archivos do Museu Nacional do Rio de Janeiro, 7:1-273. (Reprinted 1888 with errata sheet and preface by the author as "Contributions to the Paleontology of Brazil, Comprising Descriptions of Cretaceous Invertebrate Fossils, mainly from the Provinces of Sergipe, Pernambuco, Para and Bahia". Smithsonian Institution, Washington, DC.)

Woods, H. 1909. A monograph of the Cretaceous Lamellibranchia of England: Volume 2, Part 6. London, The Palaeontographical Society, p. 217-260 (Monographs 63).

Woods, M.A. \& Jones, N.S. 1996. The sedimentology and biostratigraphy of a temporary exposure of Blackdown Greensand (Lower Cretaceous, upper Albian) at Blackborough, Devon. Proceedings of the Ussher Society, 9:37-40.

Ziko, A.; Darwish, M. \& Eweda, S. 1993. Late Cretaceous-Early Tertiary stratigraphy of the Themed area, East Central Sinai, Egypt. Neues Jahrbuch für Geologie und Paläontologie, Monatshefte, 3:135-149.

Zittel, K.A. 1864. Die Bivalven der Gosaugebilde in den nordöstlichen Alpen: Beitrag zur Charakteristik der Kreideformation in Österreich. Denkschriften der kaiserlichen Akademie der Wissenschaften, mathematisch-naturwissenschaftliche Classe, 24:105-176.

Received in March, 2014; accepted in December, 2014. 
Appendix 1. List of identifiable specimens described by Seeling $(1999,2004)$, with revised determinations herein.

\begin{tabular}{cccc}
\hline Determinations by Seeling (1999, 2004) & $\begin{array}{c}\text { Specimen numbers } \\
\text { and figures of } \\
\text { Seeling (1999) }\end{array}$ & $\begin{array}{c}\text { Specimen } \\
\text { number of } \\
\text { Seeling (2004) }\end{array}$ & $\begin{array}{c}\text { NRM-PZ } \\
\text { number }\end{array}$ \\
\hline
\end{tabular}

Pholadomya $(P h$.$) cf. pedernalis$

Panopea $(P$.$) rathbuni$
Panopea $(P$.$) rathbuni$
Panopea $(P$.$) rathbuni$
Panopea $(P$.$) rathbuni$
Panopea $(P$.$) rathbuni$
Panopea $(P$.$) rathbuni$

Panopea sp.

Panopea sp.

Liopistha (P.) concentrica

Liopistha (P.) concentrica

Liopistha $(P$.) concentrica

Liopistha $(P$.) concentrica

Liopistha $(P$.) concentrica

Liopistha (P.) concentrica

Liopistha (P.) cf. alta

Liopistha (P.) cf. alta

Liopistha (P.) cf. alta

Liopistha (P.) cf. alta

Liopistha $(P$.) cf. alta

Liopistha $(P$.) supermensa

Liopistha (P.) supermensa

Liopistha $(P$.) supermensa

Liopistha (P.) supermensa

Liopistha $(P$.) supermensa

Liopistha (P.) ligeriensis

Liopistha (P.) ligeriensis

Liopistha (P.) ligeriensis

Liopistha (P.) ligeriensis
452.88, pl. 5:19

170.25, pl. $6: 4$

296.13

507.P1

507.P2

660.P1, pl. 6:2-3

660.P2

507.P3

660.P4

$170.27 b$, pl. 5:20

296.12

507.P1

$507.10 \mathrm{~b}$

652.L12a

660.C2

170.19

660.2, pl. 6:7

(erroneously as $L$. (P.)

ligeriensis in caption)

660:3, pl. 6:8-9 (error

for no. 170.17)

660.L5

660.L4

109.5

109.17

109.27, pl. 7:1-2

507.64

507.66

109.19

109.29

170.17, pl. 6:5-6, (error for no. 660.3?)

170.22
Mo 167861

Mo 167872

Mo 167873

Mo 167884

Mo 167886

Mo 167877

Mo 167878

Mo 167887

Mo 167879

Mo 167902

Mo 167903

Mo 167900

Mo 167905

Mo 167904

Mo 167899

Mo 167881

Mo 167917

Mo 167916

Mo 167918

Mo 167920

Mo 167939

Mo 167938

Mo 167937

Mo 167940

Mo 167943

Mo 167914

Mo 167919

Mo 167925
Pholadomya (Ph.) pedernalis, fig. 9E

Homomya bisinuosa, fig. $10^{\mathrm{a}}-\mathrm{C}$

Homomya bisinuosa

Pleuromya servesensis, fig. 11B

Pleuromya servesensis

Homomya brasiliensis, fig. 10D-F

Homomya brasiliensis, fig. 10G-H

Pleuromya servesensis

Homomya brasiliensis

Liopistha $(P$.$) concentrica, fig. 11 \mathrm{M}$

Liopistha $(P$.$) concentrica, fig. 11N$

Liopistha $(P$.) elongata

Liopistha $(P$.) concentrica

Liopistha $(P$.) concentrica

Liopistha $(P$.) elongata, fig. 11J-L

Pleuromya ligeriensis

Liopistha (Sergipemya) alta

Liopistha (Sergipemya) alta, fig. 12L

Liopistha (Sergipemya) alta

Liopistha (Sergipemya) alta

Megaporomya? cf. supermensa

Megaporomya? cf. supermensa, fig. 14G-H

Megaporomya? cf. supermensa, fig. 14D-F

Megaporomya? cf. supermensa

Megaporomya? cf. supermensa

Liopistha (Sergipemya) alta, fig. 12I-J

Liopistha (Sergipemya) alta

Liopistha (Sergipemya) alta

Liopistha (Sergipemya) alta 